\title{
Your Diamond Dreams \\ Cut Open My Arteries
}

Poems by Else Lasker-Schüler

Translated by

Robert P. Newton 
Your Diamond Dreams Cut Open My Arteries 


\section{IIIIUNC}

From 1949 to 2004, UNC Press and the UNC Department of Germanic \& Slavic Languages and Literatures published the UNC Studies in the Germanic Languages and Literatures series. Monographs, anthologies, and critical editions in the series covered an array of topics including medieval and modern literature, theater, linguistics, philology, onomastics, and the history of ideas. Through the generous support of the National Endowment for the Humanities and the Andrew W. Mellon Foundation, books in the series have been reissued in new paperback and open access digital editions. For a complete list of books visit www.uncpress.org. 


\section{Your Diamond Dreams Cut Open}

My Arteries

Poems by Else Lasker-Schüler

TRANSLATED AND WITH AN INTRODUCTION

BY ROBERT P. NEWTON

UNC Studies in the Germanic Languages and Literatures

Number 100 
Copyright (C) 1982

This work is licensed under a Creative Commons CC BY-NC-ND license. To view a copy of the license, visit http://creativecommons. org/licenses.

Suggested citation: Lasker-Schüler, Else. Your Diamond Dreams Cut Open My Arteries: Poems by Else Lasker-Schüler. Translated by Robert P. Newton. Chapel Hill: University of North Carolina Press, 1982. DOI: https://doi.org/10.5149/9781469656670_Lasker-Schuler

Library of Congress Cataloging-in-Publication Data

Names: Newton, Robert P.

Title: Your diamond dreams cut open my arteries : Poems by Else Lasker-Schüler / by Robert P. Newton.

Other titles: University of North Carolina Studies in the Germanic Languages and Literatures; no. 100.

Description: Chapel Hill : University of North Carolina Press, [1982] Series: University of North Carolina Studies in the Germanic Languages and Literatures. | Includes bibliographical references and index.

Identifiers: LCCN 82002656 | ISBN 978-1-4696-5666-3 (pbk: alk. paper) | ISBN 978-1-4696-5667-o (ebook)

Subjects: Lasker-Schüler, Else, 1869-1945 - Translations into English. Classification: LCC PT2623.A76 A26 1982 | DCC 831/.912 




\section{Contents}

Else Lasker-Schüler $\quad 3$

$\begin{array}{ll}\text { Notes } & 51\end{array}$

Poems from Books and Poem Cycles

Styx (1902) 56

The Seventh Day (1905) 106

My Miracles (1911) 130

To My So Beloved Playmate Senna Hoy (1917) 146

To My Pure Friend in Love Hans Ehrenbaum-Degele (1917) 158

Gottfried Benn (1917) 162

Hans Adalbert von Maltzahn (1917) 184

My Pretty Mother Always Looked to Venice (1917) 236

Hebrew Ballads (1913) 244

Concert (1932) 264

My Blue Piano (1945) 274

To Him (1945) 290

$\begin{array}{ll}\text { Identifications } & 305\end{array}$

$\begin{array}{ll}\text { Bibliography } & 307\end{array}$

Index of Poem Titles 313

$\begin{array}{ll}\text { Subject Index } & 315\end{array}$ 



\section{Acknowledgments}

Acknowledgment is made to Kösel-Verlag, Munich, for permission to translate the poems in this book.

Thanks are due to Inter Nationes, Bonn, and to the Research Council of the University of North Carolina at Greensboro for grants to aid in the preparation of this work.

Robert P. Newton 



\section{Your Diamond Dreams Cut Open My Arteries}





\section{Else Lasker-Schüler}

1.

A bulky American desk encyclopedia, undoubtedly an arbiter and repository of only the most worthwhile information, cannot find room for her slender figure between Lasker, Emanuel: German chess player and mathematician, and Laski, Harold Joseph: English political scientist, economist, author, and lecturer.

The Kleines literarisches Lexikon, in its 1953 edition, eight years after her death, gives as a capsule orientation the following message:

Lasker-Schüler, Else, lyricist, in themes, ethos, and style an Expressionist. Also stories \& dr. 1876-1945,* in Elberfeld, + in Jerusalem. Strongly improvisatory talent, alternating between pure poetry and unrestrained fancifulness. Drawn to the Orient and Judaism as if by mythical memory. Close friendship with Peter $\rightarrow$ Hille, championed by Karl $\rightarrow$ Kraus, associations with $\rightarrow$ Däubler, $\rightarrow$ Trakl, Franz Marc. Lived a bohemian life usually in Berlin. 1933 emigration to Switzerland and Palestine. ${ }^{1}$

The missing listing in the encyclopedia is not surprising, for LaskerSchüler is almost unknown in the English-speaking world and until recently has remained largely untranslated.

But even the sober, telegraphic report of the German lexicon, in itself not incorrect (save in the birth date), could hardly convey to a user the impression that she had also evoked judgments such as these:

This was the greatest woman poet that Germany ever had. ${ }^{2}$

Perhaps the greatest poet the Jews have ever had. ${ }^{3}$

Her poetry . . . belongs, in the development of modern European poetry since Baudelaire, since the French symbolists, among the highest achievements. ${ }^{4}$

The Black Swan of Israel. ${ }^{5}$

In a time in which it became difficult and rare or intolerable and conventional, she brought the love song, the love poem once more to great beauty. ${ }^{6}$

A body of love poetry that is remarkable for its wealth, its variety of nuances and its power. ${ }^{7}$ 


\section{Else Lasker-Schüler}

Some of the most beautiful love songs that German literature possesses. ${ }^{8}$

She is the Sappho of our century, a "black Sappho," for whom the world has split apart. ${ }^{9}$

The Sappho of our century would probably not have wanted to appear among chess players and political scientists anyway. She was sensitive-hypersensitive-to the company she kept. And, incidentally, she had good reason to be cautious. Not everyone was a friend, as the following charges indicate:

An extravagant unartistic style is characteristic of her, also a gypsy-like erotic sensibility. Her poetry seems more calculated and artificial than original. ${ }^{10}$

This in part perverse poetry. ${ }^{11}$

A boundlessly egoistic spirit addicted to play. ${ }^{12}$

A pathological urge to lie. ${ }^{13}$

One can doubt that Else Lasker-Schüler was ever psychologically healthy. ${ }^{14}$

A public danger, mentally ill. ${ }^{15}$

Total softening of the brain, we hear the reader say. ${ }^{16}$

Lasker-Schüler was described at various periods of her life as a mixture of archangel and market peddler ${ }^{17}$ or witch, ${ }^{18}$ as a strayed bird of paradise, ${ }^{19}$ a giggling elf or fortune-telling herbwoman, ${ }^{20}$ an inextricable chaos of genius and craziness, of megalomania and intentional eccentricity. ${ }^{21}$ Of her own changeable nature Lasker-Schüler said: "I'm not a human being, I'm weather." 22

Artists, by the very nature of their role as forces of the spirit, arouse strong sympathies in their disciples and rejection by their antagonists, but the tone of the reactions to Else Lasker-Schüler is more personal than is usual. With her flagrant eccentricities and aggressive frankness she was hard for her contemporaries to ignore, and she appears to still evoke passions and prejudices in more recent critics. Though she was given to personal devotedness, infatuations, and friendships, the emotional demands she made on others as well as on herself often strained or broke the very bonds with which she sought to secure herself in the void of her lifelong loneliness.

Because her own nature was divided, it is understandable that her critical image is not yet firmly fixed. Indeed, the existential fascination 
of her work, apart from the great beauty of language and music in a number of poems, lies in following the plight of a self-obsessed soul, threatened every moment with the loss of self, striving to find a saving union with others but always fearing its own dissolution in nothingness, the fading away of that sense of a unique being which was all it had. (Note the number of poems in the Index that begin with the word "My.") After a youth dedicated to considerable selfdramatization, so much a part of her nature that it never ceased, she faced in middle life the ominous eclipse of feeling's warmth, the petrifaction of her kaleidoscopic consciousness. She lived on then in the sustaining hope that her true and unknown essence would someday reveal itself:

I used to be an actress; now I sit in the cloakroom and burn the audience's straw hats and coats. Because I'm disappointed. I was always seeking a hand, and what lay in my hand-if I was lucky-? a glove. My face is like stone now; I have trouble moving it. One should be proud of that; no one has to erect a monument to you any longer. If only they would decorate me, at least on holidays. The more afraid I am, the more enormous my fearlessness grows. But I'm always afraid; a bird is fluttering somewhere in me, can't take flight any longer. . . . Perhaps it will begin to sing tomorrow. All my life I've been waiting for this song. ${ }^{23}$

The feelings of isolation, abandonment, and disillusion are clear, as is, in the context, the immediate source of her dejection; the passage stems from the same "letter" to Franz Marc (in The Malik) where she announces that the love of the poet Gottfried Benn for her has been extinguished.

And yet her capacity for self-identification with other beautiful souls rejuvenated quickly throughout her life-her feelings for Benn never cooled completely - and in late 1913 and 1914, only a year after the above letter, we find her involved in the fate of one of those colorful figures to whom she was always drawn and who were perhaps indeed (how can we honestly know at this remove?) somewhat as admirable and saintly as she found them.

It was a scene worthy both of her penchant for the theatrical and of the power of her loyalty:

At the end he lay in the Prisoners' Section of the Insane Asylum in Meshcherskoye four hours from Moscow. I had as I entered no longer complete control of myself. We first had to go through 8 
towers his brother and I high up between the walls. In front of every gate of the tower stood 8 armed soldiers or guards. Next to his cell (he lay with 104 degree fever pneumonia on a dreadful bed) raged insane convicts. Please don't take it as sentimentality on the wall hung my picture quite alone. He lay there worthy of adoration without complaint only a king. I was compelled to continuously kiss his hands; the kiss that he gave me on my brow is the most unforgettable blessing that could ever fall to my lot. I can't write only stammer these events for five pages. $^{24}$

Five pages, moreover, of her typically self-reliant punctuation.

The prisoner Johannes Holzmann, whose given name LaskerSchüler had reversed in its order of letters to read "Senna Hoy" (see the lyrics dedicated to him, also called "Sascha"), had been, in the years around 1904, the editor of a periodical in Berlin entitled Kampf ("Struggle"). Subsequently, his anarchistic politics and indignation at Slavic pogroms lured him to Imperial Russia, still a stronghold of reaction, where he was arrested, accused of subversive activities, and sentenced in 1907 to fifteen years of forced labor. Eight years he spent imprisoned in Warsaw and Moscow; under confinement he became mentally ill, made several suicide attempts, and finally died under the circumstances depicted above. Lasker-Schüler's appearance at the site of his Russian confinement was in pursuit of her and his brother's efforts to have Holzmann released, a man whose honesty, piety toward mankind, loneliness, and greatness she worshiped almost like a saint's, and apparently quite platonically: "They all pushed themselves on him, he was so beautiful that he was without will-power in love, I mean a work of art that can't defend itself, that one should leave untouched just for that reason. I always had an ascetic relationship with him." 25

Despite approaches to and promises of help given by highly placed personages at the Russian Court, these efforts for Holzmann's release proved in vain because of the German Embassy's clear wish to prevent his return to Germany. It expressed the fear that he might make an attempt on the Emperor's life. After the death of Lasker-Schüler's friend, his body was sent back to Berlin, where she attended the funeral: "There is something more grandiose than love, he was the person most dear to me; every shovel-full of earth that fell on his coffin also fell on my face. I felt the joy of violence, as if one were beating oneself on the face." 26

The whole episode of Senna Hoy, occurring in the feverish last half 
year before the outbreak of World War I, shows Else Lasker-Schüler in an atypically active relationship to the "real" world, and, perhaps for that reason, in an apocalyptic mood; for the year 1914 marked a turning point in her own life also, a loss of many friends to the war, a hiatus in her productive powers. Like the ill-fated arch-expressionists Heym, Trakl, van Hoddis, and others, she scented disaster in the air and seemed to long for it: "A wave is always pounding on my heart, I always have to cross God's grave. I almost think he's dead and the Bible is his gravestone. For human feelings it can only seem like willfulness - if he's alive and has turned away. I'm completely Godforsaken or pinched in between his intestines. I wish there would be a great fire. House after house should burn; I'm all aflame to ignite the entire Kurfürstendamm." 27

An Else Lasker-Schüler traveling to Moscow to negotiate with ministers of state for a friend embroiled in the imperial political labyrinths, a Lasker-Schüler invoking a vast conflagration in Berlin, her succoring cultural milieu, is a rather different Lasker-Schüler from the one customarily portrayed in bohemian dress and eccentric habit, rapidly passing through exalted affections of the heart. These latter facets of her life-often accentuated and hard to ignore-tend to mask the powerful poet who, despite her illusions and fantasy selves as Tino of Baghdad or the Prince of Thebes, was gifted with acute psychological insight, surprisingly frequent common sense, and, essential for a poet, a readiness to accept her feelings unreservedly.

In addition, though Lasker-Schüler was no intellectual, her work obviously reflects many of the problems of modern consciousness, such as the enfeebling dispersal of the central self, its alienation from the communal soul, and its radical disorientation through the loss of fixed beliefs. Though not a thinker, she held and she lived out a view of life as feeling, spontaneity, and the search for community with the world.

2.

On reality's stage Else Lasker-Schüler was a small and slender woman with a boyish figure, large, gleaming eyes-"Spanish" and "unforgettable"- -with hair worn short, a style that at the turn of the century was for a woman an attention-getter. This, of course, she welcomed. Her sense of humor and the ridiculous was marked. Her gaze was penetrating but evasive; in later years she could look angry, but as a younger woman, with her comely face and extravagant mannerisms, 


\section{Else Lasker-Schüler}

she exerted considerable fascination, even-or especially-on the gaping bourgeois youth who admired the freedoms she permitted herself. She dressed in a fashion likely to irritate the lovers of good order: unmatching blouse and skirt, red velvet jacket with golden buttons, Turkish pants and boots, a fur-piece in the summer, a jockey's cap on her raven locks. As she grew older the charm of her embellishments may have seemed less appropriate. Armin T. Wegner, otherwise quite prepossessed with the poetess, describes her appearance as that of "a no longer young oriental daughter of joy." 28

Perhaps the liveliest conjuration of her person is that of Gottfried Benn, himself a leading poet of their generation, by nature more intellectual than spontaneous, to whom for a short while LaskerSchüler was romantically attached and who maintained a relationship of respect and admiration for her until her death:

Neither then nor later could one even cross the street with her without all the world standing still and looking at her: extravagant wide skirts or pants, impossible upper garments, neck and arms decked with showy imitation jewelry, chains, earrings, fake golden rings on her fingers, and since she was continuously stroking strands of hair out of her face, these-one must admit it-servant girl's rings were always at the center of everyone's gaze. She never ate regularly, she ate very little, often she lived for weeks on nuts and fruits. She often slept on benches, and she was always poor at all times and in all stages of her life. This was the Prince of Thebes, Jussuf, Tino of Baghdad, the Black Swan.

And this was the greatest woman poet that Germany ever had. ${ }^{29}$

Yes, she was indeed eccentric, perhaps obsessed; her friends admitted it and remained loyal. In part she was eccentric from inner compulsion; her father, for example, had had no high opinion of girls, whence probably the haircut, pants, and cap, a guise she adopted in part as a young girl. ${ }^{30}$ But the eccentricity also was a form of self-stylization or mythification, the outer manifestation of the fictional personalities she adopted, a flag of the rejection of "life" in favor of "art" in the neoromantic sense of Thomas Mann's Tonio Kröger.

Beyond all this, though, she was indeed profoundly odd. For example, she claimed quite seriously that she was visited by spirits: young King David, the Angel Gabriel, her deceased grandfather. She warned people next to her table at the Café of the West not to step on 
the toes of Achmed, her black servant, supposedly standing beside her but invisible to all others. ${ }^{31}$ In the broad daylight of Berlin she once experienced her own transformation into a negroid being from primordial times, with six arms, on whose body was printed a message in an unknown alphabet. ${ }^{32}$

These visions sometimes help to explain cryptic images in the poetry. In "Leave Taking" she says her heart "hangs on every doorpost," a curious association that recurs to a childhood apparition: her heart, dark red, hanging for seconds on the doorpost of her playroom, a hallucination that, when reported to her mother, caused the latter considerable apprehension. ${ }^{33}$

It is not surprising that some prosaic critics doubted her sanity or suspected her of self-promotion, a motivation, it must be said, of which she was not completely unaware. Some of her apparent peculiarity, however, was no more than a total frankness of expression, something we-and certainly Wilhelminian Germany-are not accustomed to. She purportedly told the dramatist Gerhart Hauptmann to his face that he looked like Goethe's grandmother. (Was she so wrong?) ${ }^{34}$ She forced one couple in an audience to leave the hall before she began one of her poetry readings, since she could not tolerate their baleful "emanations." 35 And she returned from another recital to report with horror that it was attended by three hundred butcher's apprentices, each with a sharpened knife in hand, which may well have described the case metaphorically. ${ }^{36}$

It is difficult, from a distance, to resist the grotesque charm of her fancy, not to be bemused by the pride of self-significance revealed in such anecdotes, and no one reporting on or explicating Else LaskerSchüler can repress the urge to cite them. But without the wealth of her poetry she would simply be another of the numerous bohemian ladies-errant of the times, about whom entertaining tales are rife. One might mention Emmy Hennings in this connection, an actress and poetess, who turned streetwalker for a while, and who under a friend's assumed identity served the latter's sentence in jail, since the friend at the time had a conflicting theater job. (Hennings later married Hugo Ball of Dadaist fame, a congenerous madcap.) And then there was Bettina Jacometti, Dutch, a gifted artist and pupil of Aubrey Beardsley, who served some time in the French Foreign Legion without being detected as a woman. ${ }^{37}$ In the hothouse aesthetic culture of the times the exotics flourished.

With Else Lasker-Schüler the oddities begin to make sense when we pick up her poetry, where the masks are largely stripped away and in the best of which her truthfulness to human feeling and her 
self-created myth become one. We then begin to see her early erotic lyrics, her deeper devotional love poetry, the poems to her son, her effusions of melancholy and ardent religious invocations, we begin to see these all as expressions of an emotional dilemma, as a longing for close contact, to be sure, but also as a desire for complete freedom. From this dilemma the legendary identities she has assumed represent but a vehicle of escape.

In her deepest nature she remained unaffectedly childlike, a "primordial child" (Urkind), as she called her friend Peter Hille. A decent person, she said, should remain a schoolchild all his life. ${ }^{38} \mathrm{~A}$ child is playfully open to experience but easily disappointed, is dependent on the love of others but unable to recognize their own claims to attention, and does not acknowledge the advance of time or any provident seriousness beyond the moment. Lasker-Schüler confessed: "I make an effort; but I can only play, in writing too." 39 The game of writing poems she compares with her laying out of rows of multicolored buttons, a favorite pastime as a child.

Her often lonely and vagabond existence, although subconsciously self-chosen, afforded the freedom of childhood as long as she also accepted its helplessness and poverty, but she never overcame her longing for home and familial dependence: "I have no rest, am always unsettled, no home. I wish I were somebody's child. And someone would go with me into all the toy stores and buy me hobbyhorses, little bears, chests full of little houses and trees and sheep and chickens." 40 Her relationship to those she loved, even to God, was often that of a playmate or a sister. (Benn laid special emphasis on her qualities of gratitude, attachment, and limitless loyalty to friends. $)^{41}$ And wherever she was, she filled her room with playthings-dolls, animals, tin soldiers posed in battle order. It comes as no surprise that her poems make use of play imagery or that they express boundless enthusiasm for playmate friends and an equally sudden chagrin when the playmates have gone away.

This childlikeness, touching as it might be in modest doses, would soon become tedious if, behind all the games and costumes, there were not a mature and poetic awareness of common joy and sorrow, love and abandonment-one that could clothe itself in innovative, often successfully innovative, language and rhythms.

There is a "sweet and unstillable sadness" pervading her poetry. ${ }^{42}$ Taking the phrase from her own work, Gottfried Benn refers to her "unpurposed hand of play and blood" (ziellose Hand aus Spiel und $B l u t), 43$ a formula linking her freedom with her instinctual nature. She can be as naively uncalculating as a child, but it is a naïveté 
beyond good and evil that exposes all: "I have confidence in my good and bad actions. I know no sin." 44 And "What I do is well done; I don't doubt myself." 45 Though in fact Lasker-Schüler cannot indefinitely maintain this unquestioning self-confidence (she later often reproached herself for failures in her son's upbringing), there is a sufficiency of it to insure that conventional sentiment will succumb to unflinching honest impulse. An emotion she knows as "falling in love" is an essential force in her life and poetry; yet she does not hesitate to declare on impulse, "I hate and despise mankind without exception." 46

3.

Shortly before the poetess-to-be celebrated her second birthday, undoubtedly in an atmosphere of affectionate middle-class pomp, the Emperor of the Second German Empire was proclaimed with deadly serious pompousness at captive Versailles on 18 January 1871. It was the beginning of the "founders' age" with its rapid growth of economic prosperity and political ambition in a newly united Germany, a nation of growing pride, of flourishing scientific and cultural activity, but also of developing social problems, worker unrest, and rising tension, where an entrenched authoritarian governing class was forced to confront the opposing claims of the increasingly self-confident laboring and commercial classes. In this multifarious and dynamic but also egoistic and materialist society, artists tended to see one of two paths for their development: either they questioned these trends and viewed the world through magnifying naturalistic glasses, noted in studied detail its sordid imperfections and oppressive forces, siding finally with the social sufferers; or they consciously broke with the "real" world and pursued art as the ultimate goal, as an absolute claim on and animating force of the human spirit. These latter, the champions of aestheticism, were not indifferent to human pain, but they saw art as the possibility of triumph over the world's fatal insufficiency. It is this second path that Else Lasker-Schüler chose to follow. But of course her life was profoundly affected by the world as it rapidly changed, try as she would to ignore the passage of time.

For years her birth date was given as 11 February 1876, the date she adopted at the time of her wedding to Herwarth Walden. Only long after her death was the true year of her birth, 1869, uncovered by Emerich Reeck. Reeck went on to unearth, in a yearbook called Wer ist's, a further fictitious birth date promulgated by the poetess, 1881, 
and Jürgen Wallmann found that in exile in Zurich she had advanced it an additional decade, to 1891 , hence claiming herself to be forty-eight at a time when she was already seventy and looked it. ${ }^{47}$ Obviously she was more than normally afraid of aging. To attribute this to a "pathological urge to lie," as Reeck does, reveals an almost equally pathological rejection of the role of illusion in her life (and in many other people's lives). Before puncturing Lasker-Schüler's spiritual balloon, what Jung calls psychic inflation, we should reread Ibsen's Wild Duck and ask whether accurate records outweigh the productive vital lie.

Among the familial antecedents of Lasker-Schüler were merchants, wine dealers, and bankers; one relative was Leopold Sonnemann, the founder of the Frankfurter Zeitung. Her father, Aaron Schüler, was a not unprosperous private banker in Elberfeld, near Wuppertal, whose grandfather had been a rabbi in Gesecke. Aaron Schüler, according to Else's accounts, was a roguishly playful man, given to joking, a town character whose special pleasure lay in "building," probably actually the financing of home construction. At any event, he was not an architect as she claimed. He encouraged his daughter in her dislike of school, preferring to take her to the circus; later, apparently after an injury or illness when she was eleven (she claimed she had jumped from the tower of her house onto an awning), she was tutored at home. From her father she inherited her sense of humor and a considerable talent for drawing, on which she later relied in part for her living and which came to full flower in her son. A picture, fictitious in many respects, is given of her father's family in the story "Arthur Aronymus: The Story of My Father" (1932), as well as in a drama of similar name (1932). Strangely enough, Aaron Schüler does not appear in her poetry at all. But his relationship with her may have disturbed in some way Else's later relationships with other men, as Cohn suggests. ${ }^{48}$

Lasker-Schüler's mother, Jeanette Kissing, was descended ostensibly from a Spanish Jew who had fled a pogrom in Madrid, had gone to England, and later removed to southern Germany, his son adopting there the name of Kissing. This report is given by Else, who depicts her mother as a sensitive and dreamy, refined, somewhat abstracted, and melancholy woman who read a great deal and had literary gifts herself, and who taught her daughter to write. The mother greatly admired figures such as Napoleon, Goethe, and Petöfi, and it was from her that the poetess acquired her proneness to romantic enthusiasms as well as the literary impulse. Jeanette Schüler 
played a dominant role in her daughter's emotional development and is the subject of a number of poems ("My Quiet Song," "My Mother"). She died when Lasker-Schüler was only twenty-one, but the latter's unstilled longing for her mother's maternal protectiveness and companionship persisted throughout life. "I loved my mother ardently; she was my friend, my icon, my strength, my absolution, my emperor." 49 "I felt like eternal life beside her who had brought me to the world." 50

There were five children older than Else. She was especially close to and worshipful of her brother Paul, seven years her senior, after whom she later named her only child. He was an imaginative and sympathetic brother, alive to nature and of a religious bent, who, according to Margarete Kupper, had intended to convert to Catholicism but died at the age of twenty-one before doing so. ${ }^{51}$ Of the remaining siblings, Anna, the next oldest sister, continued to be the closest to Lasker-Schüler until the former's death in 1912. The poetess seems to have had infrequent contact with the rest of the immediate family in later years, except with Anna's daughters Edda and Erika.

The Schüler household in Elberfeld was a typically bourgeois home of the times, the center of family and social festivities and of cultural interests, untouched by major cares. Lasker-Schüler regarded her youth as a lost paradise of peace and security. She dreamed away her time in school and enjoyed little success, save in religious instruction; even in early years, she tells us, the tale of Joseph and his brothers entranced her. It is part of her self-evolved legend, but confirmed by other sources too, ${ }^{52}$ that she avoided reading; at any event, with a few exceptions like Richard Dehmel and Hugo von Hofmannsthal, she seldom comments on other writers. Of course she knew Nietzsche, Däubler, George, to name only a few, but when queried about contemporary authors she typically replied that she knew them personally-why should she read them? "I'm beginning to ask myself whether I'm intellectual or dull,"53 she says, and, "I personally get headaches from any kind of study. Let one celebrate my ignorance." 54 Yet whatever her mental endowments may in fact have been, she was subject to an overpowering burden of ennui from an early age. As a small child, she writes, she climbed into that same tower of the Schüler house (recent researchers claim the house had no tower ${ }^{55}$ and cried out to the people below, "I'm so bored!"

She was not bored as a child by endlessly laying out patterns of colorful buttons and by playing rhyming games with her mother; she hated off-rhymes, she says, ${ }^{56}$ though her poems have many. We are 


\section{Else Lasker-Schüler}

informed that she first composed poetry at the age of five, ${ }^{57}$ and she afterwards maintained that the poems in her first volume, Styx, originated in her fifteenth to seventeenth years. ${ }^{58}$

A cloud of mystery covers the period of her adolescence and young womanhood. In her autobiographical writings Lasker-Schüler is primarily interested in giving the mythical truth of her life, but even in this form she has little to say about these years.

We do know, however, that in 1894, at almost twenty-five, she married Dr. Berthold Lasker, a physician, and moved with him to Berlin, the burgeoning, strident capital of the German Empire. Here she also established a studio for her artistic work. It is with this marriage that her personal destiny begins to unroll. Dr. Lasker seems to have been a rationalistic and ethically rigorous man, hostile to spontaneous love as his wife knew it, a man with whom Else was not happy from the start. He was, incidentally, the brother of that same Emanuel Lasker, world chess champion, mathematician, and philosopher, who managed to win the attention of the desk encyclopedia. The two later coauthored a drama, The Story of Mankind (1922).

In September 1899, Lasker-Schüler's son Paul was born, but it was possibly not the son of Berthold Lasker, though he gave it his name. Dieter Bänsch has discovered parallels to this situation in passages from The Nights of Tino of Baghdad. If accepted autobiographically, they indicate both that Lasker-Schüler met the child's father in May of 1898 and that her infidelity - which is what she herself claims it was-was sparked by the "blind glances" of her husband and by her own unhappiness with her position as a woman. ${ }^{59}$ However, Sigrid Bauschinger surmises that the child may well have been Lasker's and the infidelity another of the poetess's self-invented legends. ${ }^{60} \mathrm{But}$, at the time, even a mere hint of suspicion would have been inevitably disruptive because of the rigid Wilhelminian code of honor, however hypocritical that code may have been.

Lasker-Schüler later asserted, in a letter to Karl Kraus, that Paul's father was a Greek named Alcibiades de Rouan. Bänsch, from clues in the work mentioned, believes that he was possibly indeed Greek, but the aristocratic name sounds unconvincing and could easily be a mythical trapping. At any event, the hypothetical Alcibiades de Rouan "died," she claimed, and played no further role in the poetess's life. Her son Paul, however, was from then on the only relatively stable center of her later years. Lasker-Schüler and her husband separated at this point but were not officially divorced until just before her next marriage. 
After separation, Else and the child lived for a time in a dungeonlike basement that she rented from a concièrge for 75 pfennigs monthly. From this banishment she was rescued by Peter Hille, one of the first alter egos she literarily enshrined, and by other members of the "New Community" (Neue Gemeinschaft), which is described by Bänsch as a "half philosophical, half aesthetic colony of life-reformers, which had become a sort of homeland for Hille and for which Hille was a walking monument. The effect on Else Lasker-Schüler of the programmatic beliefs of this Order of the True Life, so-called by Julius Hart, cannot be overestimated. They simply decreed the inner unity of the self and the world, the vacuity of all opposition as mere conceptual illusion and, conclusively following from that, the power and capacity of human beings to redeem themselves." 61

Bänsch's work on Lasker-Schüler is motivated by the sociocritical impulse to debunk the progressive beatification of the poetess which had been initiated by some earlier hagiographers; he sees the New Community as a "late bourgeois doctrine of salvation," mingling elements of monism, chiliastic idealism, and the notion of restituting nature's integrity, a doctrine deluded in its "total negation of extrasubjective resisting forces." 62 Obviously such views would be quite compatible with Lasker-Schüler's instinctive tendency to incorporate the world into her ego and would, as well, provide a philosophical justification for her mode of life, including-from the conventional viewpoint - the social shame of her (possible) marital unfaithfulness. The belief in a divine immanence could easily metamorphose into a worshipful devotion to, and identification with, those with whom one fell in love and could spread the warm glow of ontological necessity over what otherwise might seem to be a mere random meeting of empty strangers.

In an essay "The New Man" (1901), a title anticipating expressionist prophecies, Julius Hart expounds: "God is nothing but that which lives, and our life is God. By living we do not seek but are the truth. For life is all the truth-and in every moment goal and fulfillment."63 These ideas are clearly reflected even in a quite late essay by LaskerSchüler, "The Child among the Months," in Concert, which offers an uncharacteristically discursive presentation of her religious thought: "I explain to myself God's omnipotence in the world like the mother to the child. . . . We are here to work on the primordial colossus of the world, to empower it, to keep the universe alive, to breathe uninterruptedly. Now insofar as we refined egoists serve the cosmos, we remain alive. Whoever kills himself or his neighbor out of love or 
enmity becomes a thief of the force of breath that maintains the motion of our Father's created work. My deeply drawn breath unites me with the universe." 64

This neoromantic mysticism strove to replace the security of traditional faith, which more and more seemed to be a mere historical artifact, by merging the individual with the undifferentiated, encloaking All, a resort perhaps more familiar to some readers in the works of Hermann Hesse (Siddhartha, "Klein und Wagner.") With Else Lasker-Schüler, although it persists as a basic inclination, the unio mystica is often displaced in her poetry by a more anthropomorphically familial relation to the deity as a playmate, lover, or father. But even this relationship is often weakened by skepticism or an anxious search for the absconded God.

Among the neocommunitarians it was Peter Hille (1854-1904), sometimes dubbed the "Verlaine of Berlin" and a legend in his own right, who replaced for Else her lost brother and mother. Along with their close spiritual affinity as fantasts and eccentrics, the two shared a Westphalian background, though he was Catholic and she Jewish. Gerhart Werner terms Hille a literary gypsy and vagrant, the first hippie of German literature, yet a very prolific writer. ${ }^{65} \mathrm{~A}$ big man with a flowing beard, he wandered through Germany, Italy, and Switzerland, spent two years in London, and was director of a traveling theatrical group in Amsterdam. Through it all he carried with him in brown bags his literary productions-aphorisms, novels (Semiramis, Cleopatra), rhapsodic poetry-his manuscripts written on odd bits of paper, envelopes, bills, cigarette packs.

Hille was fifteen years older than Lasker-Schüler. Their relationship remained fraternal, but it contained an obvious erotic component that was sublimated into mutual ecstatic admiration. Both lived with the New Community and moved in the artistic circles of the café world. After his untimely death in 1904, she exalted him to the status of a prophet and saint and wrote The Peter Hille Book (1906), a mythification of their first encounter and following friendship. Its various legendary personages undoubtedly represent "existences" known to Lasker-Schüler and Hille in the bohemian milieu of Berlin. From this latter-day Saint Peter derives the often-quoted description of Else Lasker-Schüler as "the Black Swan of Israel, a Sappho whose world has split apart. She glows childlike, in primeval darkness." 66 The poetess dedicated the poem "The Fallen Angel" to Peter Hille.

It was Hille who invented Else's first mythical identity as Tino of Baghdad. He also called her "Tino-Queen of the Ultimate Passions," "Dreamtino," and "Mohammed's Wife." She amplified the legend in 
her book, The Nights of Tino of Baghdad (1907), a protracted, orientally lush, and lyrically diffuse fairy tale, which contained in addition a number of her early poems. The first poetry to be published, we should interpolate, had already appeared in 1899 in the periodical Die Gesellschaft ("Society"). A first volume of verse, Styx, came out in 1902 and a second, The Seventh Day, three years later (1905). These poetic works will be discussed separately.

Thus, Else Lasker-Schüler was already a recognized literary figure as well as a personality in café circles when, on 30 November 1903, she entered into her second marriage. Georg Levin was a literatus and composer whom she had met in Hille's social ambient. ${ }^{67}$ At the time of the wedding they had already been living together for an unknown period. Taking her cue from Hille's delight in assigning pseudonyms, Lasker-Schüler renamed her husband Herwarth Walden, a cognomen under which he became immortalized in literary histories as the editor, beginning in 1910, of the expressionist periodical Der Sturm ("The Storm.") A number of Lasker-Schüler's poems appeared in its pages in 1910 and 1911--actually before the magazine's fully expressionist period, which dates from 1913-but this association accounts for her later being grouped with the expressionist poets, an historical link that is still questionable. One might, of course, point out as common defining features of the poetess and the cultural movement an elevated level of pathos, heightened metaphoricity, experimentation with the forms of language, and freedom of versification; but, as noted before, Lasker-Schüler lacks the utopian world-reforming or apocalyptic impulses of the prototypical expressionists, of the Werfels, Bechers, Heyms, Trakls, Stadlers.

Walden was a hyperactive cultural entrepreneur, always engrossed in new promotions, considered by some to be arrogant and ruthless with his friends. His wife esteemed him highly as a composer, and he set some of her works to music. But, although he spread her literary fame, there were problems in their liaison from the very beginning, and these were not eased by poverty and a nomadically hectic life together. Indications are that, as a divorcée and a woman once involved in an affair, she was not accepted by Levin's family. For her part, she continued to live in her realm of fantasy, while he, in return, was unfaithful with a quite real Swede, a woman he later married. In addition, she worried about the effect of their irregular life on her son Paul. A crisis and separation came in 1910, divorce in 1912. Some writers attribute the breach to his infidelities, others to Else's difficulties with human contact. At any event, the result for LaskerSchüler was a new traumatic failure in love and a magnified sense of 
isolation. In spite of this, she often defended Levin in later years in his literary feuds, even against Karl Kraus, an important patron of hers, when the latter attacked Der Sturm. Their relationship had been from the first, as Gehlhoff-Claes notes, "a fraternal alliance against the world." 68

But the time of this personal misalliance was one of creative efflorescence for the writer. Styx, The Seventh Day, The Peter Hille Book, The Nights of Tino of Baghdad, and The Wupper all appeared in the German bookstores. The Wupper, a drama that consists of a balladesque sequence of episodes, is set in her native Wuppertal; it is sometimes naturalistic in language but otherwise lyrically subjective. Poetry written in this period appeared in My Miracles: Poems (1911) and in the later Collected Poems (1917).

The atmosphere of Lasker-Schüler's life with Levin can be divined in My Heart: A Love Novel with Pictures and Really Living People (1912). This "novel" is actually a collection of "letters" to Levin and a friend, ostensibly dispatched while the pair was in Norway but continuing to be conveyed to them through Der Sturm even after their return home, an oddity that the authoress herself casually remarks on in the letters. It is, nevertheless, the first of the larger prose works to abandon the fantasies of the Peter Hille Book and Tino of Baghdad and is interesting both for the vignettes drawn of the poetess's life in Berlin's bohemia and for its personal, religious, and philosophical reflections. Along with stretches of straight reporting-often still in characteristically grotesque romantic metaphors-My Heart also introduces the Prince of Thebes, Lasker-Schüler's second mythical personality, who gives the name to another short collection of orientalizing fantasies published in 1914. Further interesting essays, both autobiographical and on literary and artistic figures, were collected in Visions: Essays and Other Stories (1913). Lasker-Schüler's nonfantasy prose writings are a profitable source book for the prewar Berlin milieu, as well as a diary of archetypical self-obsession, however flippantly expressed, and they should be taken more seriously than they have been.

After her divorce from Levin, Lasker-Schüler never again had a permanent residence. She lived in hotels and pensions and in the evenings haunted the lively cafés with their marble-topped tables, the Café des Westens and the Romanisches Café, to taste a bit of "objectivity," away from the daze of artistic self-preoccupation that prevailed in her shabbily old-fashioned rented quarters. Upon occasion she was evicted from her café table for failing to place an order, the fate of the perennially penniless. Impractical with money (she usually gave it away as soon as she got it), she was not beyond 
expressly lusting after it: "If I only had money. Money! Money! Money! Money! . . . "69 A friend, Katharina Otto, reports that LaskerSchüler stole a picture by Oskar Kokoschka during a party in an imposing Berlin home, but later she "donated" it to a Kokoschka exhibition..$^{70}$ Some income was produced by her books, though she felt cheated by her publishers, one and all, and attacked them vivaciously in Cleaning Out! (Ich räume auf! 1925). She slapped a publisher once in the foyer of a theater and claimed her hand was guided by an archangel. ${ }^{71}$ More income derived, however, from articles and public readings of her poetry (in extravagant "oriental" costume, with flutes and bells), performed in Kurt Hiller's Neopathetic Cabaret and in Munich, Zurich, Vienna, Cologne, Dresden, Königsberg, and Prague. In Prague she was arrested for disturbing the peace while orating "in the Arabian language" about her destiny to twenty-five companions from a "niche" of the cathedral. But, even in sum, these activities could barely support her. The well-disposed critic Karl Kraus solicited contributions for her through his periodical Die Fackel ("The Torch") in 1913, and a helpful amount was forthcoming, showing that her art-which after all was her saving raison d'être-had not gone unnoticed.

But she was not happy, as we read in her letters to Karl Kraus. She felt her life was loathsome, ruined, a failure; she was "so alone." The brighter moments were due to her friends and her young son Paul.

Paul, who was the subject of a number of her poems and whose death at twenty-seven occasioned her beautiful "To My Child," was a gifted boy in whom she saw blossoming everything that was blurred and withered in herself. ${ }^{22}$ Her claims for his beauty, charm, and early talent are confirmed by others; he was, for her, kissed by "a breath from the Gods" ("My Child"). She admired his truly "artistic," i.e., not "intellectual," nature, his roguish playfulness, and his scorn for everything pretentious. Like her, she felt, he was seeking happiness and the miracle of love; he was not only her son but also her little brother, "the person with whom she could always communicate without difficulty" (Gehlhoff). ${ }^{73}$ As a boy she took him with her on Sunday afternoons to the Café of the West, where he sat quietly at one of the marble tables behind the steps and drew. His youthful artistic talent was apparently genuine and was recognized not only by academic artists but also, among others, by Franz Marc, the expressionist painter of "Blue Horse" fame. A friend of Lasker-Schüler who died in the war, Hans Ehrenbaum-Degele (coeditor with Paul Zech of Das neue Pathos, "The New Pathos"; see the poems dedicated to him) left money in his will to further Paul's training. Lasker-Schüler 
never ceased to blame herself for not providing properly for him. Although her poems to him suggest a playful, loving, and attentive parent ("The Baboon Mother"), she could not or would not be other than she was, and it was almost inevitable that he enter the same vagabondage as his poet-mother; she saw in him an "enchanting Don Juan, seeking the one and only." 74 According to Bauschinger, his later work did not live up to his early promise. ${ }^{75}$

Lasker-Schüler seems to have had, as Hans Cohn puts it, "a gift for making friends and also for antagonizing them." Cohn goes on to say: "Whatever the fate of her relationships, some of her most successful poems are penetrating evocations of the personalities of her friends, most of them artists and writers. These poems are 'objective' in the sense . . . [that] the poet's feelings about people she knew and loved have crystallized into poetic portraits of great insight and precision."76 We can assume these friendships were genuine-many, men and women, displayed their loyalty to the poetess before and after her death-but that need not mean that unrelieved contact with Lasker-Schüler was easy or that the romantic cast of many poems of friendship reflects, in every case, a serious, long-term attachment. To call it an erotically tinged affection might, in most cases, be closer to the mark.

Her worshipful friendship with the imprisoned radical Johannes Holzmann, who, like Peter Hille, served as a brother-surrogate, falls in the period between her second divorce and World War I. Her Platonic but strong and lasting links to him, as well as his unhappy end, were depicted at the outset of this Introduction. To him are dedicated the poems "Ballad," "My Love Song," "A Love Song," "A Song of Love," none of which reflects an actual erotic relationship, and also "Senna Hoy" and "Sascha," with its pensive lines: "Strange that we never kissed/Our whole life long" (which seems to describe more accurately how things stood, according to her letter to Karl Kraus). Even in death, Johannes was her guardian angel ("Senna Hoy"), interposed reassuringly between her and the terror of dying. The verses: "And I am incomprehensible to our friends/And become a stranger" (since his passing), suggest that Holzmann, like Hille before him, provided social mediation between Lasker-Schüler and a world of less beatific acquaintances.

Karl Kraus, the Viennese author and critic, was the friend most helpful to Lasker-Schüler's career. They were, of course, not in daily contact but corresponded rather frequently between 1909 and 1923; in her letters she addressed him variously as the "Cardinal," the "Dalai 
Lama," and the "Duke of Vienna," and she reveals a surprising "career consciousness."

Kraus published some of her poetry in Die Fackel, a periodical influential in literary circles. He called her a "great poet" and in particular praised her poem "An Old Tibetan Rug," a poem that, he said, "belongs for me to the most enchanting and touching I have ever read. And there are few from Goethe on down in which, as in this Tibetan Rug, sense and sound, word and image, language and soul are so interwoven." 77

On two occasions when the poetess was in financial straits (1913 and 1925), Kraus appealed with success for contributions from his readers, and in general he seemed to serve in the office of father confessor, at least from Else's point of view. But their friendship foundered on Lasker-Schüler's maternal pride and, she would have said, on the critic's lack of "heartfeltness" (Innigkeit); specifically, she was mortally offended that Kraus had not invited her son Paul to visit while the latter was sojourning in Vienna. The final words in her last letter to Kraus during the period of their closeness were: "I hate you."

Perhaps her most famous friend or beloved was the poet-doctor Gottfried Benn, who came on stage with the restive expressionist generation, flirted briefly with the radical conservatism of the 1930s until disillusioned by the National Socialists, and then resurfaced after World War II as the doyen of modernist poets. His early work, fusing the aesthetics of ugliness with a cool, nihilistic intellectuality, could hardly seem further removed from the ardent impetuosity of Else Lasker-Schüler. But moments of despair and alienation were also not unknown to her, and she undoubtedly admired his somber, unflinching gaze and his courage in ignoring poetic convention: "He descends into the vaults of his hospital and dissects the dead. Insatiable to enrich himself with mystery. . . . Long before I knew him I was his reader; his volume of poems-Morgue-lay on my blanket: horrible miracles of art, reveries of death, that assumed contour. Sufferings gape their maws and are silent, cemeteries wander into the sick-wards and take up position before the beds of pain. Women in childbirth one hears screaming from the delivery room, on to the end of the world. Each of his verses a leopard bite, the spring of a savage animal. Bone is his stylus, with which he resurrects the word."'78

They met in 1912, and the "affair" was actually a brief one, ending probably in $1913 .{ }^{79}$ Though she seems to have fallen passionately in love with Benn, his feelings were less strong, but he always remained a loyal admirer of her personally and of her work. Her, as usual 
rather extravagant sentiments are described in The Malik: An Imperial Story (1919), a series of letters to Franz Marc: "I have indeed fallen in love again. Even if I fell in love a thousand times, it is always a new miracle; [whereas it's just] the old nature of things, when someone else falls in love. ... His brain is a lighthouse. He is one of the Nibelungs." 80

Yet in the very next letter she must regret the fading of his love, and she then lapses into a vein of desolation, proclaiming herself tired of life, both bored and fearful, loving no one in the world anymore. This is the same letter from which we earlier quoted the passage: "My face is now like stone, I have trouble moving it." 81

The real fruits of this adventure were the numerous poems dedicated to Giselheer the Barbarian, namely Benn: "Oh, Your Hands," "To Giselheer the Heathen," "Pure Diamond," "The Song of the Playmate Prince," "I Hide behind Trees," "To Giselheer the Tiger," "O God," "Listen," "Turned Inward," "Only for You," and "To the Barbarian." These poems reveal in turn her passion, her affection and quiet devotion, her uncertainty and disappointment, and her ultimate forsakenness. Clemens Heselhaus has observed that in the poetry written to Benn the "tone is much more personal than in the other dedicatory poems. The literary allusions are abandoned. Only after being separated from Benn does she return to her orientalizing metaphors and emblems." 82 In the poems to Benn we find some of her strongest and most original love poetry.

The encounter was not without lasting effect for Benn also. It has been suggested by F. W. Wodtke that Benn's poems "Ein Mann spricht," "Drohung," and "Madonna" were influenced by LaskerSchüler's work, as is evidenced by their surrealistically visionary language and imagery and, one might add, by their rhythms. ${ }^{83}$ Benn's second volume of poetry, Söhne (Sons, 1914), is dedicated to her. But the most direct response is found in Benn's poem "Hier ist kein Trost" ("No Solace Here"), which, with its beginning verses, "No one will be my road's edge./Let your blossoms fade away./My road streams and goes alone," is a stern reply to Lasker-Schüler's "Listen": "I am your road's edge./She that skirts you/Plunges down."

In the same year, 1912, the poetess also made the acquaintance of the artist Franz Marc. Marc and his wife were eager to get to know the author and invited her to their home in the mountains of Bavaria, whence she, forlorn in the vast spaces of the Alpine landscape, fled to urban Munich. Franz and Maria Marc visited her there in her pension, where they found her staging mock battles on a tabletop with tin soldiers. ${ }^{84}$ Lasker-Schüler felt an affinity with Marc's work, in 
which she recognized her own "respect for divine life in all creatures." 85 To Kraus she wrote in 1915: "He is such inexplicable splendor you can hardly believe that it's possible, he is the cover of the Bible ... and what he writes from the war [Marc was at the front] dissolves again here in my hand into blood or flag or something." 86 Marc auctioned his picture "The Dream," dedicated to the Prince of Thebes, to contribute to the fund for Lasker-Schüler. ${ }^{87}$ She dedicated to him the poem "Prayer" ("I'm searching for a city in these lands") and, after he fell in battle, memorialized him in the prose poem "Franz Marc." Letters she had written to him from 1913 to 1917, originally published in several periodicals, were collected as already mentioned in The Malik (1919), with, as in My Heart and The Prince of Thebes, numerous drawings by the author as well as by her artist friends, including Marc. Even more than in My Heart, The Malik records clearly that syndrome of ennui, narcissism, and alienation, along with the belief in the momentarily restorative powers of aestheticized love, which we associate with decadent writers such as Hofmannsthal and Rilke, the former of whom she despised, incidentally, for what she felt was his conscious literariness and lack of imagination. The narcissism is literal: "I have been taking opium for weeks. . . . My comrades are cowardly and miserable creatures. At night I play lover and beloved with myself; actually we're two boys. That is the chastest love-game in the world, love without goal or purpose, lovely lewdness. . . . I long now sometimes at least, if only for an evil person." 88 It is not impossible that we hear an echo of Nietzsche here, whom Lasker-Schüler credited with having created "the language in which we all write poetry." 89 She claimed to have seen Nietzsche in the decade of his madness.

Little is known about her acquaintanceship with the poet Georg Trakl, whom she met in Berlin in early 1914. Cohn assumes that their common understanding rested in part on Trakl's (presumed) incestuous relationship with his sister and Lasker-Schüler's search for a brother; ${ }^{90}$ to Werner Kraft the poetess is reported to have expressly stated: "I always wanted a brother as a lover, then at least you know what you have, and you don't need to despise yourself."91 Trakl would certainly have known Lasker-Schüler's "Ballad from the Mountains of the Sauerland," which appeared in Styx (1902) and employed the incest motif. The autistic, cheerless, and forlorn young Austrian poet might easily have recognized himself as a figure similar to the one in the poem whose "head has been turned/By a devil of a woman/His own sister."

Her sympathy with Trakl finds expression in two poems, both en- 


\section{Else Lasker-Schüler}

titled "Georg Trakl." One is a short epitaph-Trakl, a drug addict, died from an overdose of drugs while serving as a medic during the war-and the other is a fine example of one of her fortes, the lyrical portrait sketch of a friend. Here she catches his abstracted nature and his essentially Protestant, guilt-ridden somberness. Margarete Kupper also identifies the poem "To the Knight of Gold" as being addressed to Trakl. ${ }^{92}$

Too numerous are Lasker-Scüler's more and less famous friends and acquaintances for them to be dealt with individually, but they include, along with her fantasy titles for them (where such exist): Franz Werfel (The Prince of Prague), Richard Dehmel-these first two she especially admired as poets-Georg Grosz, Oskar Kokoschka, Ernst Toller, Theodor Däubler, Albert Ehrenstein, Paul Zech, Peter Baum, Paul Leppin (The King of Bohemia), Hans Ehrenbaum-Degele (Tristan), Adolf Loos (The Gorilla), and Hans Adalbert von Maltzahn (The Duke of Leipzig). In letters to Kraus, Lasker-Schüler especially recognizes the attentions paid to her by Werfel, Grosz, and Däubler. (See the insightful lyrical portraits of the first two, as well as those of Richard Dehmel, the Duke of Leipzig, Peter Baum, and other artist friends.) These concise studies with their telling touches of colorful imagery are among her finest achievements.

During the years of European armed conflict and subsequent political and economic turmoil, until the death of her son Paul in 1927, no major external changes are recorded in her life. Lasker-Schüler lamented the Great War and expressly rejected it in The Malik, but she did not actively protest in the political realm either the war or the events of the twenties. Emotionally she sided with any suffering and opposed the destructive animosities of parties, nations, and religions, but she was not by nature equipped to deal either pragmatically or ideologically with the real world of political action.

Although her play The Wupper premiered in Berlin in 1919, it did nothing to revive her fortunes; the drain of lost friends went on. Her lyrical productivity slackened after the appearance of Collected Poems (1917), which contained many of the poems to friends. The earlier Hebrew Ballads (1913), a display of concentrated creative power applied to biblical figures and motifs, was poetically one of her highpoints. Several of the poems speak in the persona of Joseph, an identity that Lasker-Schüler had also adopted in The Malik, there too in the form of Jussuf of Egypt. From childhood, so she reports, she had cherished the figure of the biblical Joseph, perhaps, we might speculate, because of his abandonment by his brothers (reflecting her own outcast feelings) and his later role as a savior.

By the relentless calendar it was 1932 before new poetic work ap- 
peared in book form-in Concert. This volume contained predominantly prose essays and sketches, in some of which we come upon notable passages on the questions of love and friendship, Judaism and Christianity, and the religious impulse in general. An increased transcendence of the self is detectible in these reflections, a greater awareness of the community of human fate, a tempering of her exacerbated uniqueness. Lasker-Schüler during these years, without relinquishing her artistic pride or yielding a commensurate scorn for the bourgeoisie, increasingly loses the youthful afflatus that had borne her and admits to the bitter realization that she is ignored, that she has drifted to the periphery of the world's attention: "I no longer have any desire to be pushed into a corner, fear nobody for example, have always revenged myself and request that my humility not be confused with toadyism. There's a revolver in my hand somewhere. I respect my poetry myself but I want people to respect highly my life of hunger that I've led and perhaps also my thieves' existence." 39

In a chill Berlin December, in 1927, her son Paul died of tuberculosis after a long illness, a loss that cast her, now fifty-eight and bereft of her closest alter ego, to the lowest level of her life. At the point of death he requested her to step behind a curtain in the room so that he might die alone-a tragic moment of implicit rejection for a woman to whom her son had seemed the very possibility of hope. ${ }^{94}$ She never quite accepted the finality of his death; a letter written to him, prompted by a dream, is dated 1939 . This incapacity surely stemmed from her strong identification with him and from her unaccepted feelings of guilt.

Although too late, perhaps, a tardy recognition finally came with the award of the Kleist prize in 1932, a satisfaction more than voided by the events of 1933 and her pell-mell flight into exile before the antiSemitic and antiexpressionist drive of the National Socialists. Berto Perotti reports that she was knocked to the ground with an iron bar by Nazis in Berlin, and, still dazed, boarded the next train to Zurich. ${ }^{95}$ Without means, she was picked up for vagrancy in a Swiss park by the police, and only then was the support of the Swiss literary public mobilized. Lasker-Schüler eventually managed to continue publishing in Swiss and exile periodicals, but the shock of her precipitous banishment still reverberates in the poem "Chased Away!" In 1936 a dramatic version of the mythologized story of her father, $A r-$ thur Aronymus and His Fathers, was given several performances in Zurich through the agency of exiled German theater people. Its wellmeaning, but by that time politically naive, intent was to reconcile Christians and Jews by good example.

Earlier, in 1934, the poetess had traveled for the first time to Jerusa- 
lem, for her a legendary Eastern land of escape like those envisioned in Tino and The Prince of Thebes but also the homeland of the Bible. Thus Jerusalem was not only a place of refuge but in her imagination a Holy Land that was symbolically interwoven with her fate, for an emotional attachment to Judaism had remained a constant all of her life.

The immediate Palestinian realities of ethnic terrorism and social need, therefore, found little expression in the chattily anecdotal and sentimentalized travel account Land of the Hebrews (1937), which also recalls episodes in her youth that are perhaps more psychologically significant than literally true. In 1937 she returned to Palestine a second time, and after the outbreak of World War II in 1939, her third sojourn became permanent. By then she was over seventy, although she would not admit it, was tired, ill, irritable, and driven. Impecunious because of her generosity and improvidence, she lived austerely in an unheated room and slept in a chair for want of a bed. But she had friends again, and her playful spirit had not entirely forsaken the septuagenarian; she cleaned the floor by tying oily rags around her feet and skating across it.

As ever, Lasker-Schüler fell in love, wrote poetry (indeed, some of her most beautiful love poems), held readings, and organized a lecture society. She constantly gave to others whatever she had but refused to accept casual charity for herself, believing that the artist must remain free, independent of others. Her last volume of poetry, in no way inferior to the earlier ones, came out in 1943 with the title My Blue Piano. A last fragmentary play, "I and I," was written during 1940 and 1941.

Else Lasker-Schüler died quietly in Jerusalem on 22 January 1945 of angina pectoris. At the end of her life she is reputed to have questioned whether the making of poems served any purpose, ${ }^{96}$ and her last words are said to have been: "My end is coming. I can't love any more." ${ }^{\prime 97}$ At her burial in the Jewish cemetery on the Mount of Olives, Rabbi Kurt Wilhelm read her poem beginning "I know I must soon die." During the period of Arab occupation, the building of a road removed traces of her grave, but later the tombstone was rediscovered. It contained only her name and, as she would have wanted, no record of her age in mere empirical time.

Currently, the best and most complete account of Lasker-Schüler's life is given by Sigrid Bauschinger in Else Lasker-Schüler: Ihr Werk und ihre Zeit, a balanced and detailed presentation to which the reader (of German) who seeks fuller access to the poetess's life and work is referred. 
Characterizations of Lasker-Schüler and interpretations of her work have customarily emphasized the antinomies of her nature, conflicts that are tragic for her at times, at better moments lightheartedly amusing, but in any case borne with an irreducible vitality. Her riven being can be read even in the outward occasions of her life: on the one hand, her strong, anarchic urge for independence and the boldness to break traditional taboos in dress, habit, and sexual mores; on the other, her at times infantile need-including a practical need-for the support of her patrons and friends because of her radical thriftlessness, the distraction of her mind, her refusal to calculate consequences, and the "touching helplessness" she seemed to admire in herself, about which she says: "I've noticed that even the roughest person is conquered by my fear." 98 To the very end of her life the memory of her mother, the Magna Mater in her pantheon, remained a critical emotional support.

Spiritually, the dichotomy lies between her romantic, universalized self-obsession ("I am my only immortal love") and the threatening weakness in her sense of identity. ${ }^{99}$ Her difficulties in making true contact with other persons, her fear of disappointment, and her failure to find lasting love as she dreamed it and sought it were in constant conflict with an anxious search for identity, which had to be bolstered by fantastic masks, and with a longing for sublimely sublimated eros, which led to an insatiable appetite for (and consumption of) friends, a flight from the stifling emptiness of self. As a consequence, throughout most of her life, she could report herself simultaneously lonely and in love, ecstatic but depressed and bored.

Many critics have chosen to stress the religious longing that wells from this forlornness of the self, and indeed the authentic ardor of the later religious poems (in My Blue Piano and Concert) contrasts sharply with the more playful or mythologizing cast of the earlier ones. Kupper claims for Lasker-Schüler "a consistent concept of life that is essentially religious, with the longing for the redemption of the irredeemable world (heillose Welt) as its central idea." ${ }^{100}$ Martini, too, thinks of her demand for absoluteness as a basically religious need. ${ }^{101}$ From her youth, the images and symbols of Judaism and even of Christianity nourished her feelings and poetry, and especially toward the end of her life she addressed God humbly and personally. But in youth and the middle years, doubt and skepticism were also expressed quite frequently, and through most of her life the love songs 
addressed to more palpably human beings absorbed her spiritual energy.

It was rather to love that she looked, most often, for her "salvation." That love probably cannot offer it, at least not the rapturous "falling in love" that was Lasker-Schüler's mode, was likewise her tragedy; neither beloved nor friend could bear up beneath, much less requite, the intensity of her feelings and their implicit demands for the partner's unconditional surrender.

Others have detected in the poetess a potentially utopian social vision. Horst Laube writes that Lasker-Schüler was "in becoming totally conscious of herself, on the way to a radical new world of purely correct images," 102 but even in Laube's context it is not clear what establishes the "correctness" of an image. The very notion is a contradiction, since a "correct" metaphor is a generally accepted designation and therefore no longer a metaphor. Bänsch, author of a useful if overdrawn critique of the established religious and sentimental image of the poetess, claims to be setting free through his analysis the "energy of her poetry that is directed toward changing the world," i.e., "that which is apocalyptic, the break with tradition, radicalism and the uprising against the bourgeoisie."103 A much more negatively inclined critic, Marianne Lienau, maintains that it is precisely in this respect that Lasker-Schüler failed, that she did not transmute her iconoclasm into a "utopian model," and that furthermore her equation of "inspiration" with "revelation" implies social regression to a claim for the poet's unquestioned authority. The poetess's unintellectual, emotional boundlessness precluded the kind of self-critique that would have revealed to her her "real" and restrictively bound role in society. ${ }^{104}$

One can indeed cite passages in Lasker-Schüler's prose that show a consciousness of the real social world, e.g., the essay "Poor Children of Rich People,"105 and it is beyond question that LaskerSchüler saw herself as a member of the aesthetic elite and as an antagonist of the domesticated, monied middle class. But any such sociocritical assignment of her class position will not clarify the spirit of her poetry. If we insist upon it, her work collapses as a mere symptom of the alienated decadence of the late nineteenth-century bourgeoisie; then Laube and Bänsch are wrong and Lienau is right. But probably her work will interest us only if we find that it deals with a universal human plight, rather than presenting us with a sourcebook for sociological analysis.

Many, including myself, will prefer to read Lasker-Schüler in a more personal perspective, will see in her human fate the quandary 
of life's loneliness, a "longing for a second face" that, in the end, must be "content with itself," as Hans W. Cohn has put it. ${ }^{106}$ Cohn's English-language study of the poetess's "Broken World" discriminates among the strands of her poetic work and demonstrates the various stages of a "diastole of opposites," a dialectic of "withdrawal" and "outgoing."107 The backward movement proceeds in the stages: disappointment and resentment; despair and isolation; escape into fantasy (childhood, lost paradise, mother, play, masks); and finally preoccupation with death (death wishes, death-in-life, death as transition, and conquest of death.) The forward or outgoing movement rises from the longing for contact, through the erotic encounter (sexual need, wish for union) to the search for God (Judaism, the Bible, Jewish mysticism, changing images of God, the figure of Christ, Jerusalem.) This dialectic scheme outlines a reasonably complete cata$\log$ of motifs and themes in a useful perspective. ${ }^{108}$

Like any abstract, however, it cannot capture the breathing creatures of poetry-here, the strong and vivid moments of an impulsive woman seeking devotion, or the chill vastation of her abandonment, whether abandoned through death or the faithlessness of others or by her own unconscious instigation. For the receptive reader, I think, Lasker-Schüler's brief and simple poems will still deliver her urgent telegrams of joy and fear, though at the time of their dispatching they may not always have evoked the desired response from their addressees.

\section{5.}

The present volume contains translations of poems collected in the Kösel-Verlag edition: Else Lasker-Schüler: Gedichte 1902-1943. LaskerSchüler or her publishers often included previously published poetry in later, differently titled volumes, sometimes in a slightly altered version, so that occurrence in a given volume does not always indicate the time of original appearance. Here the poems are usually in their original context (as found in the Kösel edition) save for a few second versions that have been preferred to the first, some poems that first appeared in prose works, and several poems presented here among the thematically unified Hebrew Ballads (1913) although their first occurrence was earlier.

As is usually the case with translations, the poems selected are mainly those that yielded adequately to my own efforts at translation and, in the original, are successful as a whole or include some interesting passage; but there are some that are simply meant to add to the 
variety of representation or to illustrate a remark in the Introduction. Needless to say, not all of those in the last two categories belong to the irreducible stock of timeless German lyrics and, of course, other critics might wish to include, or exclude, other poems.

At times, fully rhymed originals have been rendered in only partial rhyme or with a somewhat different scheme; comparison with the facing German text will make this clear. A number of good poems I have not yet been able to translate with sufficient fidelity to the original form, and these are unfortunately absent; they are often the longer poems with more complicated stanza schemes. Since the freeverse poems translate most readily, they are overrepresented, but in my opinion it is often just these in which Lasker-Schüler's entrancing rhythm and cameo images most excel. Somewhat less than half of the total Kösel-Verlag collection is offered here.

Though the basic themes of Lasker-Schüler's art persist through all of her books, lines of thematic and formal development do exist; for ease of comparison the poems are separated by volume in the table of Contents. Her first-born (Styx, 1902) contains, if we may believe the poetess, some poems that had been written in her adolescent years, from the age of fifteen to seventeen. In this volume she had not yet developed her most characteristic metrical style - the two- and threeline, free-verse strophes-but her rhymed forms are often handled freely in terms of meter and stanzaic structure. The use of extravagant, grotesque, intensifying metaphor is already her own. The main themes-love, dejection, religious feeling, her child-are all convoked, but verses astir with a candid erotic passion are more prominent than in her settled years, and, on the whole, the taste of the times shows through. But despite its reflection of literary fashion, the volume contains some fine lyrics.

Echoes of neoromanticism, decadence, and art nouveau can be heard in the titles: "Jealousy," "Instinct," "My Blush," "Nervus Erotis," "Vagabonds," "Old Spring,, "Orgy," "Fever," "Eros," "Sensual Ecstasy"; or, in the fashion of romantic demonism: "Damnation," "Chaos," "Weltschmerz," "The Fallen Angel," "Suicide," "Guilt," "Unhappy Hate," "After-Pain," "Revenge," "The Fear Deep in My Blood."

The desire for love is there, and for union, both sexual and spiritual. Complete union is the goal, a spiritual state that rejects real circumstances and exists at a perpetually high pitch. It cannot, like simple friendship, be induced or cultivated; it either takes place between two people or it does not. Lasker-Schüler deprecates mere "love," which is bourgeois, compared with her own overpowering 
"falling in love" (verliebt sein), a faculty in which she knows that few can match her, for, in the same breath she goes on to say, "Or somebody must have loved me. Did you love me, Herwarth? Who loved me?"109

She herself did not hesitate to give the answer: she herself. For the love that remained true after the disappointment of unresponsive and unfaithful lovers was narcissistic; "I am my only immortal love," she said at one time, with obvious pleasure in her aphorism, however painful the fact. ${ }^{110} \mathrm{~A}$ friend, Grete Fischer, opines, "She was in love with love. I hardly believe that she was in love with the men about whom she speaks with such enthusiasm."111 The poetess confided to Karl Kraus, "I know so many people I write a love poem for six people together"; and "The only important thing is how I give expression to the models. I have nothing further to do with them"; and "I only need people to furnish my stars."112 She wrote to Walden, "I never perceived people other than as a frame in which I put myself."113

But it would be a mistake to press this psychological catechizing to an extreme. Unquestionably she had known real love--for Peter Hille, Gottfried Benn, Johannes Holzmann, her son, her mother. And despite the professional cynicism of the artist in her bons mots to Karl Kraus, her friends and Lasker-Schüler herself record repeated infatuations on her part until advanced age; the beautiful "A Love Song" appeared in her last book. Shades of Goethe! (And was Goethe always "really" in love?)

She may have been well aware that these fleeting enchantments were a game, but it was her vital game, the talent, along with her gift for language, that gave meaning to her life as a homeless transient. Love was for her a source of vitality and a resurrection of the spirit, the counteractive to hate and violence, as we read in the poem "Autumn," where her memories of National Socialist torchlight parades may also be invoked: "Eternal life to him who can say much of love./ A being of love will rise most certainly!/Hate boxes in! High though the torch may flare above."

It is less clear what we are to think of Lasker-Schüler's personal erotic propensities. There are some torridly beautiful verses in Styx, for example in "Sensual Ecstasy" or in these lines from "Fortissimo": "And our desire came breaking loose/And hunted us in blood-storm swells:/We sank into the Smyrna moss/Gone wild and screaming like gazelles." The arsenal of images in the early poems is bristling with fires, conflagrations, glowings, pourings, sinkings, plungings. Curiously enough, we have no way of verifying to what extent these 


\section{Else Lasker-Schüler}

poetic visions record actual desires or erotic adventures. Other than her possible but puzzling affair with the father of her child, the nebulous Alcibiades de Rouan, it is difficult to pin down a specifically sexual encounter, although it is sometimes assumed her relationship with Benn was such. To be sure, Kurt Hiller accused her of seducing young poets to win their loyalty "in a base way"; but this unchivalrous charge aroused her intense and apparently honest indignation. ${ }^{114}$ Here, offended honor was involved, but, in addition, a kind of aesthetic prudishness can be detected in what she allegedly said to Sigismund von Radecki: "The physical act by which a human being is created is something so impossible that it is only justified when two people, because of their love, simply can't do otherwise." 115 Nevertheless, in her own prose writings, more reliable than Radecki's report, what we find is a balanced view of spiritual and physical love, not at all Victorian or Wilhelminian: "I am thence at least capable of understanding man's body, which God created after his primordial image. And I wonder why one should despise this image, the flesh, the covering of the soul, especially since we enjoy the foliage of the forest, luxuriantly dense, and of each individual tree; why not the beauty of the bodily temple, which preserves in itself a treasure, the most holy, the soul."116 The imagery here is itself probably sexual. The body, i.e., sexuality, was for her in her later essayistic writings a pathway to and for the soul. Lasker-Schüler sees even the prostitute's profession as just a pretext; even she is only looking for a residue of paradise: "Love is always a psychic possession, sexuality its chalice. To reject sexuality thus would mean not to respect the body that hosts the soul. This often occurs erroneously. But I think sexuality is to be condemned which isn't seeking love's paradise. I praise the Don Juan, who, through all the hearts, is only seeking the paradisical one. Naturally there is a love, prepared in the love-light of God's East, which needs no chalice."117

Cohn maintains that this latter, unchaliced love is given pride of place by Lasker-Schüler. ${ }^{118}$ This does not necessarily emerge from the passage or the context, although it is true that platonic relationships such as hers to Johannes Holzmann ("Senna Hoy") were important occasions of her life, almost parareligious experiences. Yet the above passage was written from the viewpoint of a woman in later years and need not express the attitude of the author of the Styx. Actually, only the poems themselves tell us about the force of eros in Lasker-Schüler's youth, and if we believe them-even discounting a bit of literary pose-it was a drive of which she was much aware, whether or not (very likely not) it was promiscuously indulged. Cohn 
himself points out the candor and mature psychological self-observation of poems like "Instinct," where "the expression of sexual need does not betray any feeling of guilt." 119

Both specific and oblique sexual imagery abounds in the poetry. In contrast to the body-soul harmony promulgated in her later prose writings, the sexual drive may be depicted as an uncontrollable force or attack to which she submits will-lessly ("Instinct"), or as a torture ("Instinct") or narcotic ("Sensual Ecstasy"), while in another mood it is felt as a joyful, inseparable union of rushing cataracts ("Viva!") or the wild rapture of gazelles ("Fortissimo"). In "Knowledge," she celebrates the "primal cry, the song of Eve," whose "longing was the snake"; and in "Flight of Love" (from The Seventh Day, her second book of lyrics) a lover "leaped with me on the winds,/Godwards, until our breath gave way." The whole spectrum of the sex drive's sometimes alien, sometimes exultant, but always overmastering force is clearly projected from: "Let's whet our lusts in hellish heats" ("Vagabonds") to "Now like two children let us play" ("Spring").

Yet there are also indications of resentment at the power of this instinctive drive. In "Karma" the speaker mutters morosely, "In a night of stars all blazing free/I killed the man who was next to me"; and in "His Blood," the tormented blood (read "natural instinct") of the lover would "really prefer to pluck my joy's/Last rose in Maytime/ And throw it in the gutter slime." In the poem "My Drama" the poetess seems to resent being "lured" and thinks her beloved is, if the truth were told, "afraid" of her; she is miserable, longs for her loneliness and has learned "hate for my body, my heart's blood and him." In the uncharacteristically Gothic "Ballad from the Mountains of the Sauerland," it is the woman figure who exercises a demonic domination destructive to the man, and in "Elegy," a love "which had died young" drives her "exhausted into Satan's arms."

It has frequently been noted that there was a distinct masculine component in Lasker-Schüler's nature. ${ }^{120}$ She wore short hair and sometimes pants, before these became customary feminine attributes. Her mythical masks (in the prose) were often male-the Prince of Thebes, Jussuf of Egypt-although in her poems she normally speaks in her own woman's voice. Perhaps close identification with father, brother, son, and platonic lovers reinforced this tendency, though certainly her mother was a primary guiding figure in her life. However, the poems themselves only infrequently hint at any homoerotic tendencies, e.g., in "Old Spring." More often the relation of two ostensible males ("Pharaoh and Joseph" or "David and Jonathan") is really more like that of male and female, with the poetess speaking 
from the female point of view. Most of the imagery presupposes a feminine self-conception of freely chosen devotedness, along with the unquestioned acceptance of an emotionally strong sexual role, both experienced within the limits of an absolute personal independence. In this respect, despite some turn-of-the-century arabesques of sentiment and literary allusion, she seems to me quite modern in her realization of an autonomous femininity, with all the open potentials for gratification and disaster that any extreme autonomy of character imports.

6.

The Seventh Day (1905), the next volume of lyrics, was dedicated to her mother as Styx had been to both "dear parents." It was published by a different house, as indeed almost each of her books was; she was convinced of the exploitative intent of her successive publishers and compared their enterprises to the "bordellos of soul-merchants."121 This book, about half the size of the previous one, contains several poems considerably longer than preceding efforts ("Knowledge," "My Quiet Song") - a departure that was soon abandoned. Here also appeared some early unrhymed triadic stanzas ("Dove That Swims in Its Own Blood," "My Love Song") and the unrhymed two-line stanzas ("My Quiet Song") that proved to be Lasker-Schüler's most unique and fruitful formal innovations, later perfected into the hymnic earmark of her work. (Two brief rhymed two-liners, "Weltschmerz" and "Karma," had been published in Styx.)

Thematically, the Seventh Day is familiar, although several humorous poems open new territory ("School Days," "Grotesque"), but the best examples of her irony and grotesque humor are naturally in the prose. "The End of the World," adopting a favorite motif of the expressionists, implies the death of God, while other poems are preoccupied with human mortality, her fear of which was undoubtedly sharpened by perceiving the transitoriness of her own feelings. The poet is obviously well on the way to her personal imaginative and metric style, though literary echoes still can be heard-for example, of Stefan George in "Fighters" ("Streiter," not included here.) The best attempts are in the new rhymeless forms. 
In My Miracles (1911) we witness the ripening mastery of poems written in two- or three-line strophes or in a mixture of various versegroup lengths. Among these stand the first of the biblical poems, such as the fine "Pharaoh and Joseph," as well as her perhaps most famous lyric, "An Old Tibetan Rug."

This signatory style of Lasker-Schüler has often been compared to the metric of paralleled members (parallelismus membrorum) employed by Hebrew poetry, as in the Psalms, but parallelism in the sense of repeated syntactical structures or of the pairing of synonymous or substantively related (or contrasted) images is not present. LaskerSchüler claimed to have read frequently in the Bible, but her familiarity with it has been questioned. ${ }^{122}$ Nevertheless, in her verses as in biblical poetry we experience a comparable series of brief paratactic statements, heavy with imagery but without metrical regularity.

It may be significant, regarding the question of influence, that the poetess once claimed in her half-serious, half-ironic way that her poems were written in Hebrew. ${ }^{123}$ Because of this affinity her characteristic form has been called by Martini "mythically old and at the same time very modern. . . . Modernity was ready for the forms of the archaic,"124 an idea recalling Thomas Mann's theory of modern art in Doctor Faustus as an intellectualized reversion to primitive forms. But in Lasker-Schüler's poetry there is no trace of the "bloodless intellectuality" allied with "bloody barbarism" that is found in Adrian Leverkühn's music. Her poems give voice to the "soul" that Leverkühn lacked.

These short strophes in free verse are by no means without rhythmic principles, but they are mainly principles of proportion. There are, for example, usually limits to the number of emphatic stresses grouped in a strophe; in "Pharaoh and Joseph," in the German original, this number varies from five to nine. Strophes may show the same number of emphases in each verse or may contain both longer and shorter lines, variations in this point enlivening the rhythm. Most frequently, syntax and strophe proceed in congruence-each verse group comprises a single sentence; sometimes, however, the syntax is allowed to enjamb. Verse-end pauses may coincide with any phrasal juncture but will not intervene within a prepositional or noun phrase. More than in regular metrical poetry there is a strong interaction between breath grouping and the endings of verse and stanza. A rhythmic factor hardly to be overestimated in its importance is the overlapping enchainment of inner assonance, which does so much to 
provide continuity to the rhythmic flow. In this, Lasker-Schüler is a master. A grasp of the dynamic relationship of repeated sounds is a vital compositional skill in the euphony of free verse, and we have been told that even as a child Lasker-Schüler was sensitive to the disharmony of off-rhymes (though they litter her poems and were thus probably consciously accepted as a means of expressive freedom).

The phenomenological correlative of these devices, in concord, has been described as "dreamspun music,"125 "magical monotony,"126 or a "proclamatory tone" such as that in Old Testament poetry. ${ }^{127}$ At its best, it mildly hypnotizes and creates the same hyperaesthesia as meter, but more than regular meter it alerts the listener to the palpable objective silence that the poet's words must dominate. The images are strung in luminous isolation, each suspended in a moment of unique tension, each subject to time's immediate decay. Psychologically, the representations proceed more as in memory or in dream than as in conscious reflection or in direct reality. Lasker-Schüler has in this way realized the necessary aesthetic distance from her emotions, which tend to be unrestrained or sentimentalized. Ceremonious attention, even solemnity, reins the affections; a reposeful measuredness is insinuated by the strophic rhythm.

This dream-speech can, of course, also lapse into mere routine, a mechanical mannerism, ${ }^{128}$ but that is true in the same degree of regular metrical poetry; we are simply more attuned to, and thus unaware of, the strictures of the latter. One specific source of potential monotony in this particular form, however, is the lack of interaction between a rhythmic norm and the norm's incomplete realization in concrete language. Since there is no fixed standard, we lose the sense of variety. This is a debility in all free verse, but particularly in LaskerSchüler's short verses and sentences (as opposed to long rhapsodic lines of free verse), which arouse an expectation of proportional rhythmic form but lack a firm norm that could underline moments of expressive change. At times they may fail to escape repetitiveness and may become a "flowing into boundlessness," 129 which never reaches the intended end of movement in fulfilled repose. ${ }^{130}$ Actually, from the viewpoint of both logic and thematic development, Lasker-Schüler has occasional trouble in gathering her poems to an effective conclusion, a weakness consequent in part on her effusive, imagistic style.

A traditional topos employed by tone-deaf critics is the supposedly crushing announcement that free verse sounds no different than prose, a charge supported by typographical resetting of the poem in 
question in a prose format. Dieter Bänsch does just this with LaskerSchüler, and mirabile dictu - at the magic swish of a scholar's pointerwand-the poem indeed then sounds like prose. ${ }^{131}$ But, naturally, one has destroyed the whole structure of rhythm in the process and should not be proud of the results. The reverse transformation is just as astonishing (if not more so); real prose reset in short lines that introduce rhythmic proportions and recurrent pauses, thus focusing attention on the sounds themselves, will lead a reader to assume the heightened ethos of poetic performance.

We have every reason to believe that the finely tuned rhythm we hear in these poems was the music heard by Lasker-Schüler herself. In her recitations she was credited with a "masterful" delivery, carried by a "dark, melodic, expressive voice,"132 however odd her other sound effects (bells, flutes) and her exorbitant garb may have appeared. Her conscious theory concerning the relationship between breathing and poetry ${ }^{133}$ led her to report that she felt "bodily injury from a vowel or consonant that causes undefined disturbances in measure or hearing" (meter or sound harmony is what she probably meant. $)^{134}$ Not infrequently her regular metrical forms show deviations from their given schemes. One cannot be sure that she consciously scanned her verses (I rather imagine she would have thought that pedantry), but it is precisely in the nature of free verse that one dare spurn such Philistine niceties as scansion, and the poet's inner rhythm can hold sway.

8.

In My Miracles we first take note of recurring motifs that acquire symbolic value. These verbal counters seem to be extremely important for the poetess, even if in their later persistence they at times begin to ring hollow.

Foremost among these hieroglyphs is certainly the "star." Even visually, Lasker-Schüler was fascinated by the star as conventionally drawn; her sketches frequently imprint it on the cheek or brow of human faces, on buildings, even show it, as Philistines might expect, in the sky. Such drawings come to mind then when we read: "I am a star/In the blue cloud of your face" (from "But Your Brows Are a Storm"), where the image also bears a symbolic meaning. Her letters, too, are full of pictorial doodlings and ideographs, including frequent stars.

But the meaning of "star" as a metaphor is somewhat elusive. The 
poem "Say It Softly" begins "You took for yourself all the stars/ Above my heart," and in "Reconciliation" we are informed, "There will be a giant star fall in my womb," and in "Evening" (not included here), "A weeping angel carves the inscription/On the pillar of my body in stars." The natural and conventional symbolism of stars includes the semantic features: brilliance, distance, fateful significance, order, everlastingness. Such meanings may often be applied in Lasker-Schüler's poems; the "star" there may suggest a high, incandescent moment of feeling, or something or someone of unchanging brilliance, a lodestar inaccessible to the lower creatures of the earth. Cohn sees the image simply as a symbol of transcendence, ${ }^{135}$ which perhaps lacks in precision because it ignores the suggestions of radiance and significance. For Muschg the star is the "absolutely miraculous, the grace of love"; to bear it on one's face is a sign of the elect. ${ }^{136}$ In Georges Schlocker's view the star becomes a token of the "miraculous worlds" to which the poetess aspires ${ }^{137}$ out of her constitutional ennui.

In a little noted essay titled "Astrology," in the volume Visions (Gesichte), Lasker-Schüler contrasts the original chaos in the self, which is palpable and the source of suffering, with the "star system" in the same self, which is untouchable and regulatory: "I speak of your most invisible, of your highest part, which you cannot grasp, like the stars above you."138 The descent of God's son to earth, for example, is a "transformation from star into chaos." (Lasker-Schüler speaks figuratively here to express God's entry into the earthly being of Jesus.) ${ }^{139}$

An "undisturbed astral course" is what determines the greatness of human figures, like St. Peter Hille, ${ }^{140}$ whereas human ills stem from the collision of "stars strayed from their paths." 141 One dies of "burst stars or the chilling of your sun or from darkness." 142 In this "astrological" context, we can understand the stars as the vital determinant forces of each human fate, whose harmonious constellation and unabating energy light up the chaos of the unconscious life and whose clear radiance attracts other souls charismatically. A star as a person is a kind of spiritual guardian: "O she was a staress-/Strewed shimmering light around her" ("Alice Trübner"); or "All of my dreams hang from your gold; /I have chosen you among all stars" ("Secretly at Night"). Lasker-Schüler was not versed in conventional symbolism, but it is interesting to note in conjunction with the "Astrology" essay that J. E. Cirlot's Dictionary of Symbols, based on a multicultural survey, finds that the star "stands for the forces of the spirit strug- 
gling against the forces of darkness," a meaning that, Cirlot claims, appears worldwide in emblematic art. ${ }^{143}$

The poetess's astral views help to explain such otherwise abstruse verses as: "See my colors/Black and star" ("To Giselheer the Heathen"), where black represents material chaos and the curious adjective "star" suggests the transcendent light, both of which poles she recognizes in herself and others. In "Reconciliation," with its initial line "There will be a giant star fall in my womb," she expects a miraculous regenerative force to accompany her reconciliation with the person addressed; life will be renewed; "Whenever we embrace we do not die." The ambiguity of the word Schoß in the original of this poem, meaning either "lap" or "womb," imports a subliminally erotic image that also suggests the renewal of life through procreation. The common interpretation of this poem sees it as referring primarily to the Day of Atonement. This view is supported in the text by the prayer in a harp-shaped alphabet, i.e., Hebrew, by the overflow of God, and by the word "Versöhnung," which in German also occurs in the translation of Yom Kippur. This theory, however, overlooks the obviously given situation that a lover is addressing her beloved and the fact that the word "versöhnen" in the original appears as a reflexive ("Wir wollen uns versöhnen die Nacht"), almost certainly indicating a personal reconciliation rather than a ritual of atonement.

A closely related symbol is the color blue, which Cohn terms the "color of the spirit" or of "spiritual peace."144 Blue, Schlocker contends, is the "covering of the divine," a cue that opens vast "spiritual spaces" for Lasker-Schüler. ${ }^{145}$ Blue is in fact often associated with an immaterial realm of purity by natural symbolism; Cirlot lists thinking, truth, equilibrium, religious feeling, heaven, devotion, and innocence as correlatives of blue in various cultures. ${ }^{146}$ In "Say It Softly" the blueness of the eyes of her lover has been stolen from an archangel, and in "I Am Sad" the lover appears "Blue from [caused by] Paradise," suggesting heavenliness, calm, integrity, and innocence. The same qualities make sense of her claim in "Prayer": "I brought love to the world, and light-/So every heart can blossom forth in blue."

Gold, say Muschg and Cohn, has an erotic connotation for the poetess; ${ }^{147}$ they have in mind, perhaps, lines such as "And like the moon of gold-your body" in "From Afar," a poem not included here. For Guder it implies nobility or is mere decoration. ${ }^{148}$ In Cirlot's broader cultural view it is the color of superiority and glory, corre- 
spondent to the sun. ${ }^{149}$ It is indeed true in Lasker-Schüler's work that gold most commonly appears in the physical description of people, often to glorify the color of skin or hair, or generally to exalt the feature described. Erotic overtones are perhaps intended in "A Love Song": "A night of gold;/Stars made of night . . . /Nobody sees us"; but these are less likely in a metaphor such as "Golden icons/Are your eyes," in the poem "When I Met Tristan," also not included here.

Other motifs, such as the angel, wing, flower, sea, night, mother, and heart, would reward an effort at more exact definition, but they often adhere to the natural, conventional, or figurative implications of the words. Nevertheless, reference to Lasker-Schüler's prose is sometimes helpful. When she writes in Concert, in the essay "Friendship and Love," that unrequited love is a case of the wings of love's angel being broken, we immediately recall the first stanza of "Prayer":

I'm searching for a city in these lands

Before whose gate a mighty angel stands;

For, broken at the shoulder blade,

I bear his wings' gigantic spans,

And on my brow his star as seal is laid.

The dejected and forlorn poetess searches for the angel of love, love that is not returned but whose broken wing (the power of love's flight) she possesses and whose star (symbol of a guiding light) is imprinted on her brow-as in the sketches she never tired of drawing.

9.

Hebrew Ballads (1913) enjoys a greater degree of thematic unity than any of its predecessors. Its topics are all religious, mainly profiles of biblical figures or episodes, hardly ballads at all, but reinterpretations or original legends with a powerful immediacy of their own. This biblical involvement presages, but does not as yet fulfill, the later turn to a more personal religious lyricism. In this volume-not constricted by fidelity to the letter of the Testament-she conjures up her own visions of Abraham, Jacob, Joseph, and others, setting them in a poetic world that, as Bänsch correctly notes, is as characteristic of the turn-of-the-century scene as it is of early Hebraic history. ${ }^{150}$ The portrait of "Jacob," for example, bears little resemblance to its subject, but its titanism and narcissistic smile of defeat (or victory) would seem quite in order for a hero of the decadence.

These historical motifs produce an effect of objectivity, because the 
poems, even when spoken in the first person, are constrained in part by the factual model and hence mask to some extent the poet's subjectivity. This quality makes the Hebrew Ballads, for Hans Cohn, "the most evenly excellent of all her collections,"151 and Fritz Martini affirms that with this book she became the greatest poet of Jewish faith writing in German in the twentieth century. ${ }^{152}$

From the aesthetic point of view, these poems are indeed more consistently harmonious structures than those of the earlier creative periods. Compared with Rilke's biblical poetry, Bänsch states, they may seem "more Old Testament-like, more inelegant, more naive." "Like in an edifying book for children," Bänsch remarks, "little stories are unfolded." 153 But there are moments of terse drama in LaskerSchüler's language, the repertoire of images is refreshed, and a chiseled, archaic quality is achieved in poems like "Abraham and Isaac" or "Moses and Joshua," which is more robust than Rilke's suave rhythms and subtle perceptions.

Lasker-Schüler's relationship to Judaism was personally and culturally deep but not theologically exclusive. She called herself a "most fervent Hebrew"154 and was, as Cohn says, "profoundly conscious of being a Jew"155_even as a child she had been exposed to anti-Semitism-but her religious piety toward life encompassed everyone of comparable good faith, be it a Catholic Hille or a Protestant-born Benn. The Bible strongly influenced her themes and style; certain Judaic conceptions, such as paradise and the fall, she grasped in terms of her loss of childhood's security, and Eve became a symbol of her womanhood as did Jerusalem of the final homeland. She knew a bit about Jewish mysticism; what she was familiar with in the Jewish literary tradition is unclear. ${ }^{156}$ Yet all of these circumstances, as significant as they are, do not add up to a doctrinal faith but rather more to a tradition of religious culture. She identified with the Jewish people (see "My People") but actually more, according to Sigismund von Radecki, with the "wild, Maccabean Jews."157 In her own words, "It's fine to be a Jew . . . if one has remained true to it, grown part of it, not misled by any external triviality, but washed by the Jordan. Who can tear me away from the old skeleton of Jehovah, the unshakable rock." 158

Yet she did not countenance the fractioning of religion by a sectarian spirit. Lack of theological rigor is evident in her ambiguous attitude toward the figure of Jesus. She was not beyond calling him the Messiah or God's son, ${ }^{159}$ and she could even say, perhaps in a mood to flabbergast the middle classes, that "the Jew who rejects the Heavenly One [Jesus] proves that he is a bourgeois."160 She wrote a 
poem to Mary and often refers to the Nazarene, but it was as human figures that she was devoted to them, as part of her heritage of Jewish religious paragons like the characters of the Old Testament, "the people of the primordial stories who laid the roots of mankind."161 Her love for Jesus and his mission, for his apostles, and for early Christianity extends only through the time of the early Christians' persecution. ${ }^{162}$ In later years she wrote, "Today I am sympathetic only to individual persons, whatever their religion may be."163 Ernst Ginsberg claims that in the early thirties Lasker-Schüler was on the point of converting to Catholicism, ${ }^{164}$ but, even should that be the case (and it is not hinted at elsewhere), one should not assume it would have basically changed her eclectic religious views or her loyalty to her mythical Joseph, to "My People" or to Jerusalem. For her there was only "one faith, one God, one creation, one heaven." 165 In exile in the real Jerusalem of strife and tension, she hoped in vain to find a "reconciliation" realized and in the end, Cohn notes, found her refuge to be spiritually dead, ${ }^{166}$ a sentiment underlying the poem "Jerusalem." But not even that could mar her spirit's mythical city.

10.

No genre of the lyric is so uniquely Lasker-Schüler's as the pointillistic portraits of her beloved ones and friends, those of the former largely hymnic, those of the latter sometimes chatty and informal. Both come to the fore in the Collected Poems (1917), which adds to the reprinted earlier works those new series of poems dedicated severally to Senna Hoy, Hans Ehrenbaum-Degele, Gottfried Benn, Hans Adalbert von Maltzahn, and to "My Beautiful Mother." In the first four series are gathered some of her finest love poems in two- and three-line stanzas, works that are usually eulogistic but containing a few, particularly among those to Benn, that express the dejection of disappointed love and reproach the beloved, usually mildly. The last two series unite sketches of her numerous friends with poems to her sister and child, some of them drawn from earlier books. In "My Beautiful Mother" rhyme schemes reappear, and love poetry is absent. The portraits of friends in the Maltzahn group share the situational objectivity of the Hebrew Ballads and, like them, expand the previous range of motifs and feelings, thus breaking the spell of a style that tended increasingly toward automatism. These works vividly recreate for us the atmosphere of the poetess's activities and companionship in Berlin during the most youthfully vigorous and outgoing 
years of her life, and they add a certain ballast of social reality to the solitary, burning elevations in which the poetess confronts her beloved. Whether or not these vignettes of admiring friendship truthfully reproduce their subjects, they are at least poetic artifacts in their own right, sharply limned mosaics in bright pinpointed colors.

11.

The late poems of Else Lasker-Schüler, harvest of the sorrows of penurious years and endless loneliness, of her son's death and the terror of her flight and exile, spread a mood of resignation sometimes succumbing to hopelessness; yet they also speak the language of an increasingly humble personal piety in some of her best religious lyrics such as "God Hear . . ." in Concert (1932), "Prayer" in My Blue Piano (1943), the movingly dignified elegy to her dead son ("To My Child"), and her apotheosis of love in "Autumn." The poetess returns to a contemplation of her own experience within now accepted limits of reality and in a less mannered style. The love poems, no longer in the majority, are less imperative, more modest, more touching in their honest respect for the otherness of the beloved.

Lasker-Schüler's relationship to God began in childish fantasy and ended in childlike faith. The God of her earlier poems may at one moment be a playful young father, wagging a finger with forced jollity at an even younger rascal of a poet ("In the Beginning"), while only shortly later it appears that God has precipitately aged and died ("End of the World") or at least absconded. "God, where are you?" she asks in "To God" (not included here). Bänsch quips that she treats God as one more poetic figure among others, almost as a painted decoration. ${ }^{167}$ But there is also a real and lasting skepticism in her soul. We have previously quoted her letter to Karl Kraus in 1914, when she was already forty-five years of age: "Waves are always beating on my heart; I always have to go over God's grave; I almost believe he's dead and the Bible is his tombstone. For human feelings it can only seem like willfulness-if he lives and has turned away."168 True to decadent rhetoric, Satan plays in the early poems a more reliably present role than God ("Damnation," "Elegy").

Her feelings are marked by a vacillation between skepticism and a picture-book image of God the Father, between fear of his disappearance and the devotion of the mystical bride. She admits, "It is so easy to assert that there is no God"169 but confesses too, "I was always busy digging, not for gold but for God. I didn't dig for the 
eternal out of bold arrogance but from religious adventure-lust."170 The tone of her late poems is caught in an essay entitled "My Devotion," from Concert: "I rely on God, because how often I have put my pain and joy into his hands." 171 At this point she has apparently overcome the doubt that is prompted by the perennial problem of theodicy: how it is that God's omnipotence can tolerate evil, in particular the suffering of her soul, which longs to be devout? The world of the suffering body is here seen as an illusion, a mere "crystallization of the soul's homeward longing for protection in God the Father's hands," 172 and it is thus of lesser reality. Perhaps she should have said, "God the Mother," because God's protectiveness toward the world is seen as the relation of mother and child. ${ }^{173}$ In any event, in her last poems a child's trustful submission to the parent's will is the experiential ground of her faith. God has become an imperative and not just a poetic image with which to convey charming beliefs or resentful desolations.

The propensity toward faith was a lifelong implication of her divided character: her constitutional commingling of sharp anxiety and dulled feeling, her sense of being a lonely outcast in society and yet suffocated by its grip, this latter an impression that in several respects-culminating in her persecution and forced exile-was only too close to the truth. God's was then the only reassuring love that would never reject or disappoint.

Her letters, real and fictional, repeatedly report that she is alone, ${ }^{174}$ even though she knows nice people, ${ }^{175}$ even in the Café of the West. ${ }^{176}$ She cannot find a bridge to anyone's soul. ${ }^{177}$ "Nobody can get to me, I can't get to anybody." 178 She loves no one, ${ }^{179}$ and no one loves her. ${ }^{180}$ Life is purposeless; one takes refuge in one's self: "We're only on the way; life is just a way, has no arrival, because it isn't coming from anywhere. Where should one go anyway? Take refuge in yourself! That's why people are so poor, their hearts are asylums; they feel themselves secure in their sociable homesteads." ${ }^{181}$ She is driven to "flee mewards," in her "Flight from the World."

"I could never be compared with other people," she opined in a letter to Herwarth Walden, ${ }^{182}$ and she thought of herself as an Indian, a Robinson Crusoe, a Theban prince, Joseph the Egyptian, anybody but a mere Frau Else Lasker-Schüler, put down like a million others with their inexorable birth dates in a file in an archive in a swarming city somewhere on the Brandenburger flats. Her fantasy worlds were theatrically cozy homesteads envisioned by a homeless wanderer, who also, repeatedly and to great effect, burned bridges she had not yet built across the human stream. 
But the stage behind these fantastic props stood empty again as soon as the poetess's audience had left. She was bored, benumbed, but apprehensive and afraid of death:

I cannot find myself again

In this dead abandonment!

It's as if: I lie world-far from me

Among gray night of old anxiety.

["Chaos"]

Urangst, "old anxiety," is for Cohn a key word, expressing the mood of her "rootlessness and isolation." 183 It is the pathos of self-abandonment and helplessness, draining away the essential elán of life. In "Spring Sorrow" this "repose of death" is to be revivified by an infusion of her lover's warming "spring-like blood," for probably, as in "Revenge" (not included here), "Death spent the night in my soul/And ate my springtimes." This ebbing of vitality is the victory of death's forces ("The Fear Deep in My Blood"), which, on more manic occasion ("Youth"), is roundly defied: "Why me in the City of the Dead,/Me, whose rejoicing's just begun." Symptomatically, a condition of listless dread and paralysis of feeling gives way to a spell of rebelliousness: "And my soul lies there like a pale, wide plain/And hears life grinding in the mill,/Dissolving in a heavy chill,/And gathering hot for battle once again" (in "Fighters," not included here.) With the passing of youth, however, the resistance of sheer animal vitality had to give way to courage or to faith.

In the prose works Lasker-Schüler's depressive ennui is plainly described. She is "restless with fearful boredom."184 She is tired of life and wants to die adventuresomely: "I'm fed up with everything, even the leaves on the trees. Always green and always green. If only I'd meet some magical people, I mean some who had grand wishes, but they are all serious, only I am in earnest. I'm so lonely-whoever looks at me for a long time will fall into a dark-heaven."185 "I'm through; I hate to wake up in the morning because I hate the world; I don't want to sleep because I dream of the world."186 She clearly recognizes that this spiritual vastation is the obverse of her spiritual freedom: "I no longer have anything to hold on to. . . . I never made a system for myself like smart women do, never fortified a worldview like still smarter men, I haven't built myself an ark. I am unattached." 187 Because she was unattached personally (especially after the death of Paul) and to an extent also socially (especially in exile), and because she served no ideology other than her art and found it to be unrecognized even in her Promised Land, she in the end turned 
back to her happier beginning and saw the power of love in herself not as hers to be requited-as such it had overpowered both others and herself-but as a divine presence: "Holy love which you blindly trampled/Is God's image." ("I Lie Somewhere by the Side of the Road," not included here.) Love is the completed bridge between herself and God, to whom she could now proffer her soul with the modesty of a woman returning a lost possession to its rightful owner: "Oh God, though it of fault be full-/Take it quietly in your hand. . . . /That, in you, it may gleam-and end" ("Prayer").

12.

The potency of love is the immanence of God. This conviction becomes not only a religious principle but an aesthetic one as well, in the form: creativity is divine inspiration, hence a revelation, a belief that leads Bänsch to speak of Lasker-Schüler's "undaunted romantic definition of art and the founding of religion" as one and the same. ${ }^{188}$ She says, "I even assert that the artist who has overcome ambition is concerned only with the Nirvana of inspiration, drifting off into sleep, the streaming away of the heart, making room for God."189 A true work of art proceeds from a state of enthusiasm (Schwärmerei; the English word literally means to have God in oneself); ${ }^{190}$ and it is this state of the soul that is to be sought, not the poet's probably faulty record of the experience: "It is not the poem that is important, but the poetic state in which one creates it."191 Put thus, it sounds quite like the expressionist poetics, which extols the poet's intensity, ethical or aesthetic, rather than the technical perfection of his actual poems. The poetic state transcends the inadequacies of life as it sadly is; it is a resurrection: "I die from life and catch my breath again in images."192 So, despite her poverty, her writing made her rich: "I've been composing poetry now for two days and two nights; I'm actually a person who has many palaces. I can enter my poetdom, as wide as a thousand mornings and nights-and I cannot lose it, and the very fact that one must pay his taxes with his blood-that is possession."193

We might be led to think that for Lasker-Schüler the poet's office is austerely sacerdotal, as it was for Stefan George. But we know already that it was also a kind of delightful game: "Whether one plays with green, lilac, and blue stones or whether one writes poetry, it's all the same, one has the same feeling of happiness, because one can't see the world any more vividly through ecstasy than through bits of [colored] glass." 194 She metaphorized her writing habits like this: "I 
write for myself primarily, let everything I've written get hard like an earth, like a star that becomes earth. Then I take the earth in my hand and play ball with it." ${ }^{\prime 195}$ Translated into everyday reality, this suggests that the poetess, after an initial flow of associations, put her creations aside and later perhaps rearranged the parts-phrases, sentences, or strophes. In many poems the array of images is conceivably commutable; the pieces could be "played" in a different sequence; but, of course, each arrangement results in differently felt emphases in the experience. Very likely the composition is not by chance. We know that Lasker-Schüler worked over and revised her poems continuously, often long after their original publication. Compare, for example, the two versions of "My Quiet Song."

Lasker-Schüler rejected the intrusion of external "purpose" into art: "I almost slapped [Stefan] George on the street" - although on an earlier occasion she had approached and wordlessly given him a flower- "I was so disappointed. Affected people! Art shouldn't educate but crown with garlands." 196 She was also distrustful of Hugo von Hofmannsthal's gracefully perfect form, especially of his Jedermann's didactic intent. ${ }^{197}$ Her own poetic labors were mainly in praise of others or were lamentations on the sorrows of the self.

Art was reception of God; it was a game with colored stones; but certainly it was not to be an exercise in intellectual or spiritual vanity, a public preening of one's feathers. Schalom Ben-Chorin reports that she did not like self-conscious talk about artistic matters, preferring to discuss-it sounds quite curious-politics. ${ }^{198}$ She once exclaimed, "You wouldn't believe how literary topics revolt me, that pluck to pieces and plunder the game, the charms of the soul. I am so alone, so barren inwardly that I scorn every sensation, every immodesty."199 A café friend whom she dubbed Cajus-Majus, Caesar of Rome, provoked her to the outburst: "If he only weren't always talking about literature! As long as it's my verses it's okay, but when he begins to blather about Aristophanes, let Dante's Inferno fetch him." 200

13.

Some of her critics wish that she had been less reluctant to think about questions of taste. In the end we must also face those critical doubts that even sympathy never spared her. The most frequent charges are: kitsch, monotony, defective workmanship-all of them true to a degree.

Marianne Lienau, one of Else Lasker-Schüler's most unforgiv- 
ing detractors, but not the only one, decries her "cutesy kitsch" (neckischer Kitsch), deplores her lack of self-criticism, and deprecates her "calamitous teen-ager tone" (fataler Backfischton). ${ }^{201}$ Apparently on political grounds, Lienau denies a gifted artist the right to say, "I don't know myself'; ;02 to do so is an asocial self-indulgence. LaskerSchüler makes a cult of her Self without examining how this Self reflects her social being. She should have learned to distinguish between kitsch and real sweetness, gaiety and silliness, originality of language and buffoonery. ${ }^{203}$

Perhaps Lasker-Schüler was herself regretting a certain sentimental indecisiveness of mind when she noted, "The teeth have fallen out of my thoughts, I think too sweetly," 204 yet this very image shows how her uncontrolled associations can forge incisive language. The boundary between sentimentality and rapture is a fine one, as Schlocker admits, ${ }^{205}$ and not only the poet but also the reader may misjudge it subjectively. One might contend that it is best to avoid these swampy borderlands of feeling. For good or ill, however, poets tend to wander quite heedlessly through all the territory they inhabit. LaskerSchüler's realm verged on the marshes of sentiment, that much is clear, and she inevitably sometimes crossed the line. Most readers will recognize this wavering boundary within her work, even within particular poems, without confining her finally to either side.

Her images, rhythms, and sentiments are sometimes repetitive. Bänsch detects a "wearying stereotypy," 206 and for Schlocker she fails to escape the "danger of playing with the worn-out coins of words."207 Particularly in the two- and three-line stanzas, Lasker-Schüler's rhythmic style can ring repetitive because of the predominant conjoining of brief rhythmic and syntactic periods, their brevity being the (negative) operative factor. When, in addition, the images are picked from her staple stock of favorite "stones" or "buttons" - words like star, blue, gold - an individual poem may not come alive, especially if read in company with others that use the same repertoire. Of course, countless other poets have cultivated personal mannerisms or rethreshed empty grain-one thinks of Trakl immediately or even Heine-but what poet has not? The greatest poets will be the most continuous fountains of innovation; the merely good ones will be graced with a score of poems in which their genius springs to life, while the rest of their works may be respectfully shelved like significant scraps from the atelier, clues to the designs perfected in the best.

Her critics have begrudged the embattled poetess even these few perfected poems, though this is surely less easy to understand. Pörtner judges himself as a critic, rather than her as a poet, when he 
concludes: "I don't know any perfect poem by her. . . . When I seek in my memory I find words, series of words, verses of poems, but no poems." 208 And Schlocker: "It is not given to the poem to reach ripeness" under Lasker-Schüler's hand. ${ }^{209}$ Or Heselhaus: "The literary significance of Lasker-Schüler lies in the individual pearls of the metaphors." 210 It has become a repetitive cliché in its own right to describe Lasker-Schüler's poems as fragmentary and without logical development. Yet, although some poems may be circular "garlands of praise," the best progressively evoke their subject and build to a rhetorical climax. It is difficult to see how this simple fact can be overlooked.

Beginning with "Spring," one can go on to name "Old Spring," "Then," "Weltschmerz," "Viva!," "Fortissimo," and "Youth," in Styx alone, as not necessarily great poems, but yet as developed, rounded, in their own way unflawed works. And who could carelessly deny the truly completed beauty of "Reconciliation," "Pharaoh and Joseph," "A Song of Love," "To the Barbarian," "A Song," "Georg Trakl," "My Quiet Song" (second version), "Prayer," "Abraham and Isaac," "Moses and Joshua," "David and Jonathan," "Esther," "Genesis," "To My Child," "My Blue Piano," "Chased Away," or "A Love Song"?

The thematic range of these songs is narrow, if the forces of love and dejection can be thought of as limited, but the sentiments ring true, and the music is haunting and original. Solipsistic LaskerSchüler may have been-eccentric, careless, paranoid, in some respects selfish. Yet the powerful glow of her eros holds transfixed for us in its beam the figures of long-forgotten people-people more practical than she, more selfless, less distracted, less anxious, less afraid of death, who did not jingle their cheap jewelry in others' faces, and who did not die with little left so far from home.

Where are they now, though?

In these few poems. 



\section{Notes}

The abbreviations in the notes indicate the following works:

$\mathrm{CH}=$ Clemens Heselhaus. Deutsche Lyrik der Moderne. Düsseldorf, 1962.

DB = Dieter Bänsch. Else Lasker-Schüler: Zur Kritik eines etablierten Bildes. Stuttgart, 1971.

DD =Else Lasker-Schüler. Dichtungen und Dokumente, ed. Ernst Ginsberg. Munich, 1951.

FM = Fritz Martini. "Else Lasker-Schüler. Dichtung und Glaube." In Der deutsche Expressionismus: Formen und Gestalten, ed. Hans Steffen. Göttingen, 1965.

$\mathrm{GB}=$ Gottfried Benn. Gesammelte Werke, Vol. 4. Wiesbaden, 1968.

GS = Georges Schlocker. "Else Lasker-Schüler." In Expressionismus: Gestalten einer literarischen Bewegung, eds. H. Friedmann and O. Mann. Heidelberg, 1956.

GW = Else Lasker-Schüler. Gesammelte Werke. 3 vols. Munich, 1962.

HB = Horst Bienek. "Else Lasker-Schüler." In Triffst du nur das Zauberwort, ed. Jürgen Petersen. Frankfurt/M, 1961.

HC = Hans W. Cohn. Else Lasker-Schüler: The Broken World. Cambridge, England, 1974.

JC = J. E. Cirlot. A Dictionary of Symbols. New York, 1962.

KK = Else Lasker-Schüler. Briefe an Karl Kraus, ed. Astrid GehlhoffClaes. Cologne-Berlin, n.d. Appended is a "Versuch einer biographischen Darstellung" by Gehlhoff-Claes.

$\mathrm{KL}=$ Kleines literarisches Lexikon, ed. W. Kayser. Bern, 1953.

MK = Margarete Kupper. "Lebenslauf," In Else Lasker-Schüler, Sämtliche Gedichte. Munich, 1966.

MS = Michael Schmid, ed. Else Lasker-Schüler: Ein Buch zum 100. Geburtstag. Wuppertal, 1969.

SB = Sigrid Bauschinger. Else Lasker-Schüler: Ihr Werk und ihre Zeit. Heidelberg, 1980.

$\mathrm{WM}=$ Walter Muschg. Von Trakl zu Brecht: Dichter des Expressionismus. Munich, 1961.

1. KL 383.

5. MS 164: Peter Hille.

2. GB 1102: Benn.

6. FM 22: Martini.

3. HC 35: Cohn.

7. HC 109: Cohn.

4. FM 6: Martini.

8. HB 189: Bienek. 
9. HB 194: Bienek.

10. DB 227: Hans Benzmann.

11. DB 227: Benzmann.

12. DB 202: Helmut Kreuzer.

13. DB 157: Emerich Reeck.

14. DB 162: Bänsch.

15. MS 186: Kurt Hiller.

16. KK 165: Rhein. Westf. Zeitung, 6 July 1911.

17. DB 167: Karl Kraus.

18. MS 189: Paul Pörtner.

19. MS 44: Teo Otto.

20. MS 163: Kraus.

21. KK 165: Heinrich Binder.

22. GW II, 406.

23. GW II, 403.

24. KK 72.

25. KK 67.

26. KK 69.

27. KK 74.

28. MS 88.

29. GB 1102.

30. DB 206.

31. MS 90: Armin T. Wegner.

32. MS 61: Schalom Ben-Chorin.

33. GW II, 689.

34. MS 102: Marianne Lienau.

35. MS 46: Teo Otto.

36. MS 118: Horst Laube.

37. MS 96: Wegner.

38. HC 61.

39. $\mathrm{CH} 217$.

40. MK 306.

41. MS 70: Benn.

42. GS 146.

43. DB 212.

44. GW II, 356.

45. GW II, 388.

46. KK 90.

47. DB 155ff. A critical account of the entire birth-date question.

48. HC 19.
49. GW II, 597.

50. GW II, 745.

51. MK 295.

52. MS 62: Ben-Chorin.

53. GW II, 373.

54. GW II, 423.

55. DB 164.

56. GW II, 518.

57. GW II, 518.

58. FM 17.

59. DB 193.

60. SB 28.

61. DB 195.

62. DB 196.

63. DB 196.

64. GW II, 738.

65. MS 160: Gerhart Werner.

66. MS 164.

67. DB 199ff; following details from Bänsch.

68. KK 157.

69. KK 167.

70. KK 167: Gehlhoff-Claes.

71. DD 579.

72. KK 84

73. KK 177.

74. GW II, 754.

75. SB 193.

76. HC 97.

77. HC 31; Die Fackel, No. 313-14 (Dec. 1910).

78. GW II, 227-28.

79. HC 27; GW II, 401.

80. GW II, 401.

81. GW II, 401-2.

82. CH 227.

83. HC 28.

84. HC 26.

85. HC 27.

86. KK 78.

87. KK 160.

88. GW II, 395, 397.

89. MS 51: Paul Goldscheider. 
90. HC 29.

91. GW III, 160.

92. MK 302.

93. KK 90.

94. HC 32.

95. MK 306-7.

96. MS 186: Paul Pörtner.

97. HB 188.

98. GW II, 321.

99. GW II, 366.

100. HC 6.

101. FM 7.

102. MS 122.

103. DB 147, 145.

104. MS 108, 109.

105. GW II, 167.

106. HC 96.

107. HC 38.

108. HC vii-viii.

109. GW II, 387.

110. GW II, 366.

111. MS 191.

112. KK 20; MS 197, 106.

113. GW II, 387.

114. KK 78-79.

115. DD 579.

116. GW II, 742.

117. GW II, 712.

118. HC 104.

119. HC 105.

120. HC 73; DD 576: von Radecki.

121. GW II, 545.

122. MS 62: Ben-Chorin.

123. HC 120.

124. FM 6.

125. GS 144: Schlocker.

126. DB 22: Bänsch.

127. GS 147: Schlocker.

128. DB 25: Bänsch.

129. FM 18: Martini.

130. DB 31: Bänsch.
131. DB 26-27.

132. MS 71: Ben-Chorin.

133. DB 24.

134. GW II, 519.

135. HC 39.

136. WM 142, 75.

137. GS 142.

138. GW II, 147.

139. GW II, 150, 147.

140. GW II, 148.

141. GW II, 146.

142. GW II, 151.

143. JC 295.

144. HC 49, 143.

145. GS 145.

146. JC 50-54.

147. HC $40,62$.

148. HC 40.

149. JC 114, 50-54.

150. DB 115.

151. HC 123.

152. FM 17.

153. DB 109.

154. GW II, 687.

155. HC 118.

156. HC 123.

157. DD 579: von Radecki.

158. GW II, 750.

159. GW II, 750, 150.

160. GW II, 149.

161. GW II, 740.

162. GW II, 727.

163. GW II, 727.

164. DB 129.

165. GW II, 687.

166. HC 149-50.

167. DB 116.

168. KK 74.

169. GW II, 742.

170. GW II, 740.

171. GW II, 742.

172. GW II, 778. 
54 Else Lasker-Schüler

173. GW II, 738.

192. GW II, 356.

174. KK 58.

193. KK 21.

175. KK 76.

176. KK 77.

194. KK 11.

195. KK 18.

177. KK 52; GW II, 399.

196. KK 82.

178. KK 80.

197. KK 137-38.

179. GW II, 403.

198. MS 58.

180. GW II, 387.

199. KK 89.

181. GW II, 373.

200. GW II, 295.

182. DD 515.

201. MS 105, 106.

183. HC 53.

202. MS 110.

184. GW II, 402.

185. GW II, 402.

203. MS 107.

186. KK 88.

204. KK 20.

187. GW II, 387.

188. DB 119.

205. GS 150.

206. DS 113.

207. GS 143.

208. MS 187.

209. GS 144.

190. GW II, 944.

210. CH 228. 


\author{
Poems by \\ Else Lasker-Schüler
}


Ich will in das Grenzenlose Zu mir zurück,

Schon blüht die Herbstzeitlose

Meiner Seele,

Vielleicht-ist's schon zu spät zurück!

$\mathrm{O}$, ich sterbe unter Euch!

Da Ihr mich erstickt mit Euch.

Fäden möchte ich um mich ziehn--

Wirrwarr endend!

Beirrend,

Euch verwirrend,

Um zu entfliehn

Meinwärts!

FRÜ HLING

Wir wollen wie der Mondenschein

Die stille Frühlingsnacht durchwachen,

Wir wollen wie zwei Kinder sein,

Du hüllst mich in Dein Leben ein

Und lehrst mich so, wie $\mathrm{Du}, \mathrm{zu}$ lachen.

Ich sehnte mich nach Mutterlieb'

Und Vaterwort und Frühlingsspielen,

Den Fluch, der mich durch's Leben trieb,

Begann ich, da er bei mir blieb,

Wie einen treuen Feind zu lieben.

Nun blühn die Bäume seidenfein

Und Liebe duftet von den Zweigen.

Du mußt mir Mutter und Vater sein

Und Frühlingsspiel und Schätzelein!

-Und ganz mein Eigen ... 
FLIGHT FROM THE WORLD

I want to go back into boundlessness,

Return to me.

Already the timeless crocus of my soul

Blossoms autumnally;

Perhaps-it's too late to return!

Oh, I perish here among you!

For you smother me with your selves.

I'd like to spin threads around me-

End the disorder!

Vex you,

Perplex you,

So I can flee

Mewards!

SPRING

Now like the moonlight let us stray

And wake the quiet spring night through-

Now like two children let us play;

Your warming life about me lay,

And teach me how to laugh like you.

I long had yearned for a mother's love,

A father's word, and springtimes merry;

The curse that me forever drove-

Since it wouldn't leave-I learned to love,

With time, like a true adversary.

Now silken trees are blossoming,

And twigs pour out love's fragrance sweetly.

You'll do my mother-and-fathering,

Be lovey-dove and games of spring!

-And mine completely ... 
TRIE B

Es treiben mich brennende Lebensgewalten, Gefühle, die ich nicht zügeln kann, Und Gedanken, die sich zur Form gestalten, Fallen mich wie Wölfe an!

Ich irre durch duftende Sonnentage . . .

Und die Nacht erschüttert von meinem Schrei.

Meine Lust stöhnt wie eine Marterklage

Und reisst sich von ihrer Fessel frei.

Und schwebt auf zitternden, schimmernden Schwingen

Dem sonn'gen Thal in den jungen Schoss,

Und läßt sich von jedem Mai'nhauch bezwingen

Und giebt der Natur sich willenlos. 
INSTINCT

The burning forces of life propel me, Feelings that I cannot restrain;

And thoughts that suddenly take shape Attack like wolf packs on the plain.

I stray through the fragrant, sunny days, And the night is shattered by my cry. My pleasure moans like a tortured groan And breaks its fetters with a sigh.

And hovers on trembling, shimmering wings To the valley's lap-bright, young, and free, And succumbs to the mastery of each May breath And surrenders to Nature will-lessly. 
URFRÜHLING

Sie trug eine Schlange als Gürtel Und Paradiesäpfel auf dem Hut, Und meine wilde Sehnsucht Raste weiter in ihrem Blut.

Und das Ursonnenbangen, Das Schwermüt'ge der Glut Und die Blässe meiner Wangen Standen auch ihr so gut.

Das war ein Spiel der Geschicke Ein's ihrer Rätseldinge . . .

Wir senkten zitternd die Blicke In die Märchen unserer Ringe.

Ich vergass meines Blutes Eva Ueber all' diesen Seelenklippen, Und es brannte das Rot ihres Mundes, Als hätte ich Knabenlippen.

Und das Abendröten glühte Sich schlängelnd am Himmelssaume, Und vom Erkenntnisbaume

Lächelte spottgut die Blüte. 
OLD SPRING

She wore a serpent as girdle;

On her hat, fruit of paradise;

And my own wild rage of yearning

In her blood, too, did rise.

And the sun's age-old terror,

The melancholy of fire,

My own cheek's pallor,

Her also did well attire.

That was a game of destinies,

One of their mystery things ...

Trembling, we dropped our glances

Into the fairy-tales of our rings.

I forgot Eve's blood-born yearning

Over all my soul's steep cliffs,

And the red of her mouth was burning

As if I had boys' lips.

And the blushing glow of evening

Snaked around heaven's hood,

And the buds of the tree of Eden

Smiled ridiculously good. 
MAIROSEN

(Reigenlied für die großen Kinder)

Er hat seinen heiligen Schwestern versprochen, Mich nicht zu verführen, Zwischen Mairosen hätte er fast

Sein Wort gebrochen, Aber er machte drei Kreuze Und ich glaubte heiss zu erfrieren.

Nun lieg' ich im düst'ren Nadelwald, Und der Herbst saust kalte Nordostlieder Ueber meine Lenzglieder.

Aber wenn es wieder warm wird, Wünsch' ich den heiligen Schwestern beid' Hochzeit

Und wir-spielen dann unter den Mairosen . . .

DA N N

. . . Dann kam die Nacht mit Deinem Traum Im stillen Sternebrennen.

Und der Tag zog lächelnd an mir vorbei, Und die wilden Rosen atmeten kaum.

Nun sehn' ich mich nach Traumesmai, Nach Deinem Liebeoffenbaren.

Möchte an Deinem Munde brennen

Eine Traumzeit von tausend Jahren. 
MAY ROSES

(Roundelay for Big Children)

To his sanctified sisters he pledged as how He would not seduce me.

Twixt the May roses he just might have

Broken his vow;

But he thrice made the sign of the cross

And I felt the heat freeze me profusely.

Now in the gloomy pines I lie,

And the Autumn's chill northeast-songs sing

Over my limbs of spring.

But when it once turns warm again,

I hope that the sanctified sisters won't tarry

To marry

And we-will play then under the roses of May . . .

THEN

... Then came the night and brought your dream

In the quiet blaze of stars.

And the smiling day went marching by

Where the wild, breathless roses are.

I long now for a May of dreams, The moment when your love appears.

I'd like to blaze upon your mouth

A dream-time of a thousand years. 
KA R M A

$\mathrm{Hab}^{\prime}$ in einer sternlodernden Nacht

Den Mann neben mir um's Leben gebracht.

Und als sein girrendes Blut gen Morgen rann, Blickte mich düster sein Schicksal an.

SINNENRAUSCH

Dein sünd'ger Mund ist meine Totengruft, Betäubend ist sein süsser Atemduft, Denn meine Tugenden entschliefen. Ich trinke sinnberauscht aus seiner Quelle Und sinke willenlos in ihre Tiefen, Verklärten Blickes in die Hölle.

Mein heißer Leib erglüht in seinem Hauch, Er zittert, wie ein junger Rosenstrauch, Geküsst vom warmen Maienregen.

-Ich folge Dir ins wilde Land der Sünde Und pflücke Feuerlilien auf den Wegen, —Wenn ich die Heimat auch nicht wiederfinde . . . 
In a night of stars all blazing free I killed the man who was next to me.

And as his murmuring blood ran toward the dawn His fate stared at me baleful and withdrawn.

SENSUAL ECSTASY

Your sinful mouth's my burial crypt, Narcotic in its sweetness, fragrant-lipped, So that my virtues fell asleep.

I drink with drunken senses from its well And will-lessly sink down into its deep, With radiant gaze descending into hell.

Under its breath my body hotly glows; It quivers like a youthful rose, Kissed by the warming rain of May. -With you to the land of sin I'll wildly roam And pluck up fire lilies by the way -Even if I never find the road back home. 
Am liebsten pflückte er meines Glückes

Letzte Rose im Maien

Und würfe sie in den Rinnstein.

... Sein Blut plagt ihn.

Am liebsten lockte er meiner Seele

Zitternden Sonnenstrahl

In seine düst're Nächtequal.

Am liebsten griff er mein spielendes Herz

Aus wiegendem Lenzhauch

Und hing es auf wo an einem Dornstrauch.

... Sein Blut plagt ihn. 
HIS BLOOD

$\mathrm{He}^{\prime} \mathrm{d}$ really prefer to pluck my joy's

Last rose in Maytime

And throw it in the gutter slime.

... His blood torments him.

$\mathrm{He}^{\prime} \mathrm{d}$ really prefer to lure my soul's

Quivering sunbeam

Into his nighttime's tortured dream.

$\mathrm{He}^{\prime} \mathrm{d}$ really prefer to snatch my playful heart

From the spring's cradling air,

And hang it in a bramble-bush somewhere.

... His blood torments him. 
VIVA!

Mein Wünschen sprudelt in der Sehnsucht meines Blutes Wie wilder Wein, der zwischen Feuerblättern glüht. Ich wollte, Du und ich, wir wären eine Kraft, Wir wären eines Blutes Und ein Erfüllen, eine Leidenschaft, Ein heisses Weltenliebeslied!

Ich wollte, Du und ich, wir würden uns verzweigen, Wenn sonnentoll der Sommertag nach Regen schreit Und Wetterwolken bersten in der Luft!

Und alles Leben wäre unser Eigen;

Den Tod selbst rissen wir aus seiner Gruft Und jubelten durch seine Schweigsamkeit!

Ich wollte, dass aus unserer Kluft sich Massen Wie Felsen aufeinandertürmen und vermünden In einen Gipfel, unerreichbar weit!

Dass wir das Herz des Himmels ganz erfassen Und uns in jedem Hauche finden Und überstrahlen alle Ewigkeit!

Ein Feiertag, an dem wir ineinanderrauschen, Wir beide ineinanderstürzen werden, Wie Quellen, die aus steiler Felshöh' sich ergiessen In Wellen, die dem eignen Singen lauschen Und plötzlich niederbrausen und zusammenfliessen In unzertrennbar, wilden Wasserheerden! 
VIVA!

My wishes sparkle in the longing of my blood

Like the wild wine through glowing branches swirls.

I wish that, you and I, we were a single power,

We were a single blood

And one fulfillment, one passionate hour,

One ardent love song of all the worlds.

I wish that, you and I, we could be branched together

When mad with sun the summer day cries out for rain, And thunder clouds are shattering in the air!

And life belonged to us two altogether;

Then, Death himself we'd snatch out of his lair

And celebrate his silence with disdain.

I wish that boulders rose from our abyss

Like cliffs piled on each other, and would flow

Up to a mountain peak unreachably far!

That we the heart of heaven might firmly seize

And find ourselves in all the winds that blow

And shine over all eternities that are.

A holiday, when together we rush along

And, drunken, into each other both will fall

Like streams that plunge from steep and rocky peaks

In waves that listen only to their own song

And suddenly roar downward, flowing to meet

Inseparably--in a wild white waterfall. 
CHAOS

Die Sterne fliehen schreckensbleich

Vom Himmel meiner Einsamkeit,

Und das schwarze Auge der Mitternacht

Starrt näher und näher.

Ich finde mich nicht wieder

In dieser Todverlassenheit!

Mir ist: ich lieg' von mir weltenweit

Zwischen grauer Nacht der Urangst . . .

Ich wollte, ein Schmerzen rege sich

Und stürze mich grausam nieder

Und riß mich jäh an mich!

Und es lege eine Schöpferlust

Mich wieder in meine Heimat

Unter der Mutterbrust.

Meine Mutterheimat ist seeleleer, Es blühen dort keine Rosen

Im warmen Odem mehr.-

. . . . Möcht einen Herzallerliebsten haben!

Und mich in seinem Fleisch vergraben. 
CHAOS

The stars are fleeing pale with dread From the heavens of my solitude, And the black eye of midnight Stares closer and closer.

I cannot find myself again In this dead abandonment! It's as if: I lie world-far from me Among gray night of old anxiety.

I wish a pain would stir And hurl me down cruelly And jerk me to myself! And some shaping desire Would lay me down, back home, at rest Under my mother's breast.

My motherland is empty-souled;

Roses no longer blossom there In the warm air-

. . . . If I but had the sweetheart of my wish! $I^{\prime} \mathrm{d}$ bury myself in his flesh. 
VERDAM M N IS

Krallen reissen meine Glieder auf Und Lippen nagen an meinem Traumschlaf.

Weh Deinem Schicksal und dem meinen, Das sich im Zeichen böser Sterne traf.

Meine Sehnsucht schreit zu diesen Sternen auf

Und erstarrt im Morgenscheinen-

Und ich weine

$\mathrm{Zu}$ den Höllen.

Schenk' mir Deine Arme eine Nacht, Die so frischen Odem strömen

Wie zwei nordische Meereswellen.

Dass, wenn ich aus Finsternis erwacht,

Mich nicht böse Geister treten,

Ich nicht einsam bin mit meinem Grämen.

$\mathrm{Zu}$ den Himmeln fleh' ich jede Nacht,

Doch der Satan hetzt die Teufel auf mein Beten.

WELTSCHMERZ

Ich, der brennende Wüstenwind,

Erkaltete und nahm Gestalt an.

Wo ist die Sonne, die mich auflösen kann,

Oder der Blitz, der mich zerschmettern kann!

Blick' nun: ein steinernes Sphinxhaupt,

Zürnend zu allen Himmeln auf.

$\mathrm{Hab}^{\prime}$ an meine Glutkraft geglaubt. 
My limbs are ripped apart by claws And lips gnaw at my dreaming sleep. Woe to your destiny, and my own That their star-crossèd rendezvous did keep. My longing cries aloud up to these stars And in the morning light turns stoneAnd I groan To all the hells.

Give me your arms as a gift for a night, Which such fresh fragrance breathe, Like two Nordic ocean swells.

So when I wake from my dark night Demons won't trample my despair, So I'll not be alone with grief.

To the heavens I send my plea each night. But Satan sets his devils on my prayer.

WELTSCHMERZ

I, the burning desert wind Grew cold and took on form.

Where is the sun that can dissolve Or the lightning that can smash me!

Look now: a stone Sphinx head Raging to all the heavens.

I believed in the power of my fire. 
MEIN DRAMA

Mit allen duftsüssen Scharlachblumen

Hat er mich gelockt,

Keine Nacht mehr hielt ich es im engen Zimmer aus,

Liebeskrumen stahl ich mir vor seinem Haus

Und sog mein Leben, ihn ersehnend, aus.

Es weint ein blasser Engel leis' in mir

Versteckt-ich glaube tief in meiner Seele,

Er fürchtet sich vor mir.

Im wilden Wetter sah ich mein Gesicht!

Ich weiß nicht wo, vielleicht im dunklen Blitz,

Mein Auge stand wie Winternacht im Antlitz,

Nie sah ich grimmigeres Leid.

... Mit allen duftsüssen Scharlachblumen

Hat er mich gelockt,

Es regt sich wieder weh in meiner Seele

Und leitet mich durch all' Erinnern weit.

Sei still, mein wilder Engel mein,

Gott weine nicht

Und schweige von dem Leid,

Mein Schmerzen soll sich nicht entladen,

Keinen Glauben hab' ich mehr an Weib und Mann,

Den Faden, der mich hielt mit allem Leben,

$\mathrm{Hab}^{\prime}$ ich der Welt zurückgegeben

Freiwillig!

Aus allen Sphinxgesteinen wird mein Leiden brennen,

Um alles Blühen lohen, wie ein dunkler Bann.

Ich sehne mich nach meiner blind verstoss'nen Einsamkeit,

Trostsuchend, wie mein Kind, sie zu umfassen,

Lernte meinen Leib, mein Herzblut und ihn hassen,

Nie so das Evablut kennen

Wie in Dir, Mann! 
With all sweet-fragrant scarlet flowers

He lured me;

Not a single night could I stand it in my cramped room;

Before his house I stole me some crumbs of love And, longing for him, ate my life away.

An angel pale weeps in me silently

Concealed-I think deep in my soul

He is afraid of me.

In the wild storm I saw my face!

I don't know where, perhaps in a darkening flash,

My eye was a wintry night in my countenance,

I never saw grimmer pain.

... With all sweet-fragrant scarlet flowers

He lured me;

Misery lifts its head in my soul again

And leads me through all distant memory.

Be still, $\mathrm{O}$ my wild angel mine,

Let God not weep

And speak not of the pain;

My suffering shall not be unleashed;

My faith is lost in man and woman;

The thread that held me to all life

I gave back to the world of strife

Of my free will!

Out of all Sphinx's stones my pain will burn,

Around all blooming, blaze like a gloomy spell.

I'm longing for my blindly banished loneliness;

Seek comfort, like my child, in its embrace.

Learned hate for my body, my heart's blood and him;

Never know thus the blood of Eve

As in you, Man! 
FORTISSIMO

Du spieltest ein ungestümes Lied,

Ich fürchtete mich nach dem Namen zu fragen,

Ich wusste, er würde das alles sagen,

Was zwischen uns wie Lava glüht.

Da mischte sich die Natur hinein

In unsere stumme Herzensgeschichte,

Der Mondvater lachte mit Vollbackenschein,

Als machte er komische Liebesgedichte.

Wir lachten heimlich im Herzensgrund,

Doch unsere Augen standen in Thränen

Und die Farben des Teppichs spielten bunt

In Regenbogenfarbentönen.

Wir hatten beide dasselbe Gefühl,

Der Smyrnateppich wäre ein Rasen,

Und die Palmen über uns fächelten kühl,

Und unsere Sehnsucht begann zu rasen.

Und unsere Sehnsucht riss sich los

Und jagte uns mit Blutsturmwellen:

Wir sanken in das Smyrnamoos

Urwild und schrieen wie Gazellen. 
FORTISSIMO

You played me an impetuous song;

I trembled to ask what its name might be.

I knew it would tell what all along

Has glowed like lava twixt you and me.

Then Mother Nature came butting in, In the mute history of our hearts;

The moon-father shone with full-cheeked grin

As if writing comical lovers' parts.

We secretly laughed in our inmost soul,

But still the tears hung in our eyes;

And the shades of the carpet brightly flowed

With rainbow-colored tints and dyes.

Both of us felt the very same;

The Smyrna carpet seemed a lawn, And the palms above us coolly swayed, And our desire came raging on.

And our desire came breaking loose And hunted us in blood-storm swells:

We sank into the Smyrna moss

Gone wild and screaming like gazelles. 
DER GEFALLENE ENGEL

(St. Petrus Hille zu eigen)

Des Nazareners Lächeln strahlt aus Deinen Mienen, Und meine Lippen öffnen sich mit Zagen, Wie gift'ge Blüten, die dem Satan dienen Und scheu den Lenzwind nach dem Himmel fragen.

Die heisse Sehnsucht hat mich tief gebräunt, In kühler Not erstarrte meine Seele, Ein Wetter stählte mein Gewissen!

Es wachsen Sträucher blütenlos auf meinen Wegen

Wie Schatten, die verbot'ne Thaten werfen, Und meine Träume tränkt ein blut'ger Regen Und reizt mit seinem Schein zum Laster meine Nerven.

Die Unschuld hat an meinem Bett geweint, Und rang und klagte dann um meine Seele Und pflanzte Trauerrosen um mein Kissen.

Siehst Du den Kettenring an meinem FingerSein Stein erblindete, sein blaues Scheinen, Vielleicht verlor ihn mal ein Gottesjünger Auf seinem Pfade hoch in Felsgesteinen. Und diese roten, feurigen Granaten

Gab mir ein Königgreis für meine Nächte, Wie heisse Tropfen auf die Schnur gereiht.

Der Sonnenuntergang erzählt im Westen Von späten Rosen, die ergrauen müssen Im Herbste unter morschem Laub und Aesten, Und nichts vom Sonnenglanz des Sommers wissen, Als Sünderinnen sterben für die Thaten Der eitelen Natur, die duften möchte Noch in der späten Winterabendzeit.

Darf ich mit Dir auf weiten Höhen schreiten! Hand in Hand, Du und ich, wie Kinder . . . Wenn aus dem Abendhimmel wilde Sterne gleiten Durch's tiefe Blauschwarz, wie verstoss'ne Sünder, Und scheu in Gärten fallen, die voll Orchideen Und stummen Blüten steh'n In gold'nen Hüllen. 
The smile of the Nazarene beams from your visage, And my lips are parted in shy hesitation, Like poisonous flowers that do the devil's bidding, And ask the spring wind about heaven's elation. My passionate desire burned me deep brown. The numbness of chill misery lamed my soul.

My conscience turned to steel in the thunder's throes.

Like shadows that project forbidden deeds Beside my paths the unflowering bushes grow; My dreams are drenched in a red rain that bleeds Exciting my nerves to vice with its bright flow. At my bedside weeping innocence sat down And struggled and lamented for my soul And planted on my pillow a funeral rose.

Here on my finger, do you see the ringThe jewel's gone blind that once so bluely shone. Perhaps a disciple lost it, wandering High on his path along the cliffs of stone. And look, these garnets, full of a red fire, A hoary king bequeathed me for my nights, Like burning drops all strung upon a string.

The sun that's setting in the west can tell Of the late roses that in fall turn gray; Under rotten leaf and branch they bid farewell

But of summer's glorious sun have naught to say; And yet as sinners for their pride expire, For nature's vain hope to be fragrant still, Even at the very end of a winter day.

On the broad heights with you-may I go striding! Hand in hand like children, you and I.

When, out of the evening heaven, wild stars come gliding, Rejected sinners through the blue-black sky; And shyly fall in gardens where flowers stand, With orchids and quiet buds abloom In a golden grove. 
Und in den Kronen schlanker Märchenbäume

Harrt meine Unschuld unter Wolkenflor, Und meine ersten, holden Kinderträume Erwachen vor dem gold'nen Himmelsthor.

Und wenn wir einst ins Land des Schweigens gehen, Der schönste Engel wird mein Heil erfleh'n Um Deiner Liebe willen.

Wilde Fratzen schneidet der Mond in den Sumpf

Und dumpf

Kreist die Welt.

Hätt' ich nur die Welt überstanden!

Damals als wir uns beide fanden

Blickte auch die Natur so gemein,

Aber dann kam der Sonnenschein

Und sang sein Strahlenlied

Bis über den Norden.

Nun nagt der Maulwurf an Deinem Gebein,

In der Truhe heult die rote Katze.

Ein Kater schlich, sie lustzumorden

Aus vollmondblutendem Abendschein.

Wie die Nacht voll grausamer Sehnsucht blüht!

Der Tod selbst fürchtet sich zu zwei'n

Und kriecht in seinen Erdenschrein,

Aber-ich pack' ihn mit meiner Tatze! 
And in the crowns of fairy-story trees Under veils of cloud my innocence will wait; And my first dearest dreams, of childhood days, Awaken in front of heaven's golden gate. And when we go one day to the silent land The fairest angel will save my soul from doom Because of this your love.

SUICIDE

The moon makes hideous faces in the swamp

And in dull pomp

The world spins round.

If only I'd endured its bother!

Long ago when we found each other

Nature, too, peered nastily;

But there was some sunshine then to see

And sang its beaming song

Beyond the North.

Now the mole's gnawing at your bone;

In the chest, the red cat's wailing.

A tomcat prowled to rape and kill her

Where the full moon bleeding evening shone.

How the night and its cruel yearnings bloom!

Even Death himself's afraid of others

And creeps into his earthen tomb,

But-with my paw I'll nail him. 
JUGEN D

Ich hört Dich hämmern diese Nacht

An einem Sarg im tiefen Erdenschacht.

Was willst Du von mir, Tod!

Mein Herz spielt mit dem jungen Morgenrot

Und tanzt im Funkenschwarm der Sonnenglut

Mit all den Blumen und der Sommerlust.

Scheer' Dich des Weges, alter Nimmersatt!

Was soll ich in der Totenstadt,

Ich, mit dem Jubel in der Brust!! 
YOUTH

Last night I heard your hammer's craft

Building a coffin down in your shaft.

What do you want from me, Death!

My heart plays in the dawn's young breath, And whirls in the spark-swarm of the sun

With all the flowers and summer fun.

Clear out, old Neverfed!

Why me in the City of the Dead,

$\mathrm{Me}$, whose rejoicing's just begun!! 
B A LL A D E

(Aus den sauerländischen Bergen)

Er hat sich

In ein verteufeltes Weib vergafft,

In sing Schwester!

Wie ein lauerndes Katzentier

Kauerte sie vor seiner Thür

Und leckte am Geld seiner Schwielen.

Im Wirtshaus bei wildem Zechgelag

Sass er und sie und zechten am Tag

Mit rohen Gesellen.

Und aus dem roten, lodernden Saft

Stieg er ein Riese aus zwergenhaft

Verkümmerten Gesellen.

Und ihm war, als blicke er weltenweit,

Und sie schürte den Wahn seiner Trunkenheit

Und lachte!

Und eine Krone von Felsgestein,

Von golddurchädertem Felsgestein,

Wuchs ihm aus seinem Kopf.

Und die Säufer kreischten über den Spass.

„Gott verdamm' mich, ich bin der Satanas!»

Und der Wein sprühte Feuer der Hölle.

Und die Stürme sausten wie Weltuntergang,

Und die Bäume brannten am Bergeshang,

Es sang die Blutschande. . . .

Und sie holten ihn um die Dämmerzeit,

Und die Gassenkinder schrie'n vor Freud'

Und bewarfen ihn mit Unrat.

Seitdem spukt es in dieser Nacht,

Und Geister erscheinen in dieser Nacht,

Und die frommen Leute beten.- 
B A LL A D

(From the Mountains of the Sauerland)

His head has been

Turned by a devil of a woman,

His own sister.

Like a lurking cat

She crouched by the door where he was at

And licked at the coin of his callouses.

At the tavern in wild revelry

They sat and drank for all to see

With rough companions.

And out of the ruby juice that glows,

From the dwarfed and stunted fellows he rose

Like a giant.

And he saw the whole world beneath his gaze,

And she stoked the fire of his drunken craze

And laughed!

And like a crown a cliff of stone,

A gold-veined cliff of stone

Grew from his head.

And all the drunkards began to laugh.

"Goddammit, ah's the Devil hisse'f!"

And the wine spewed the fire of Hell.

And the storms roared like the end of the world, And flames from the trees on the hillside swirled, And incest sang. . .

In the dusk they came to take him away And the urchins yelled in the street, "Hurray!" And showered him with rubbish.

Since then a spook walks on this night, And spirits are abroad here on this night, And the pious people pray- 
Sie schmückte mit Trauer ihren Leib,

Und der reiche Schankwirt nahm sie zum Weib,

Gelockt vom Sumpf ihrer Thränen.

-Und der mit der schweren Rotsucht im Blut

Wankt um die stöhnende Dämmerglut

Gespenstisch durch die Gassen,

Wie leidender Frevel,

Wie das frevelnde Leid,

Überaltert dem lässigen Leben.

Und er sieht die Weiber so eigen an,

Und sie fürchten sich vor dem stillen Mann

Mit dem Totenkopf.

KÖNIGSWILLE

Ich will vom Leben der gazellenschlanken Mädchen mit glühenden Rosengedanken, Wenn glanzlose Sterne mein Sterbelied singen Und bleiche Winde durch die Totenstadt weh'n Und vom Licht mein warmes Leben erzwingen.

Ich will vom Leben der wettergebräunten Knaben, die nie eine Thräne weinten, Wenn die Todé vor meinen Herzthoren steh'n Und mit der Kraft meiner Seele ringen.

Ich will vom Leben der weissen Gluten Der Sonne und von der Wolke Morgenbluten Dem quellenden Rot der Himmelsbrust.

Bis meine Lippen sich wieder färben Und junger Odem durchströmt meine Brust . . . Ich will nicht sterben! 
She decked her body with mourning-dress, And lured by the swamp of her tearfulness, The wealthy innkeeper wed her.

-And the one with the red plague in his blood Staggers in the groaning sunset flood

Like a ghost through the alleys,

Like suffering wickedness,

Like wicked pain,

Too old for life grown dull.

And he looks at the women so curiously And they fear the quiet man when they see His head like a skull.

ROYAL WILL

Give me the life of slender girls, Gazelles with rose-bright thoughts awhirl, When lusterless stars intone my dirge And pale winds sweep the city of the dead, And my warm life from the light of day is purged.

Give me the life of the weather-browned Boys who will never weep tear nor sound, When deaths before my heart's door stand And with my soul's strength struggle hand to hand.

Give me the life of the fiery glow

Of the sun and the clouds' dawn-bleeding show, The gushing red of heaven's breast. Until the red of my lips revivify And a young breath is pulsing through my breast ... I will not die! 
DIR

Drum wein' ich,

Dass bei Deinem Kuss

Ich so nichts empfinde

Und ins Leere versinken muss.

Tausend Abgründe

Sind nicht so tief,

Wie diese grosse Leere.

Ich sinne im engsten Dunkel der Nacht,

Wie ich Dir's ganz leise sage,

Doch ich habe nicht den Mut.

Ich wollte, es käme ein Südenwind,

Der Dir's herüber trage,

Damit es nicht gar voll Kälte kläng'

Und er Dir's warm in die Seele säng'

Kaum merklich durch Dein Blut.

SCHULD

Als wir uns gestern gegenübersassen, Erschrak ich über Deine Blässe, Ueber die Leidenslinie Deiner Wange.

Da kam's, dass meine Gedanken mich vergassen

Ueber der Leidenslinie Deiner Wange.

Es trafen unsere Blicke sich wie Sternenfragen,

Es war ein goldenes Hin- und Herverweben

Und Deine Augen glichen seid'nen Mädchenaugen.

Du öffnetest die Lippen, mir zu sagen. . . .

Und meine Seele färbte sich in Matt,

Dumpf läutete noch einmal Brand mein Leben

Und schrumpfte dann zusammen wie ein Blatt. 
TO YOU

I weep because

At your kiss, I confess,

I don't feel anything

And just sink down in emptiness.

A thousand voids

Are not so deep

As this vast emptiness.

I think in the closest darkness of the night

How I'll tell you very softly;

Yet I haven't strength to dare.

Would that a wind would come up from the south

To bring you word in flight,

So that it would not sound so full of cold,

Would warmly sing itself into your soul,

Through your blood scarce aware.

GUILT

When yesterday you sat there facing me Your paleness caused me great alarm, Because of the line of suffering on your cheek.

My thoughts forgot my self, surprisingly,

Because of the line of suffering on your cheek.

Our glances met like questions to the stars.

There was a golden weaving back and forth,

And your eyes were like the silken eyes of girls.

Your lips were parted and you tried to say. ... .

And then my soul lost color and went dull-eyed.

Faintly my life rang fire alarm once more

And, like a leaf then, slowly shrank and died. 
UNGL ÜCKLICHER HASS

(Versrelief)

Du! Mein Böses liebt Dich

Und meine Seele steht

Furchtbarer über Dir,

Wie der drohendste Stern über Herculanum.

Wie eine Wildkatze springt

Mein Böses aus mir,

Und beisst nach Dir.

Entrissen

Von Liebesküssen

Aber taumelst $\mathrm{Du}$

In Armen bekränzter Hetären

Durch rosenduftender Sphären

Rauschgesang.

Nachts schleichen Hyänen,

Wie brütende Finsternisse

Hungrig über meine Träume

Im Wutglüh'n meiner Thränen.

NACHWEH

Weisst Du noch als ich krank lag,

So Gott verlassen-

Da kamst Du,

Es war am Herbsttag,

Der Wind wehte krank durch die Gassen.

Zwei kalte Totenaugen

Hätten mich nicht so gequält,

Wie Deine Saphiraugen,

Die beiden brennenden Märchen. 
UNH A P PY H A T E

(Verse Relief)

You! My evil loves you.

And my soul stands

More fearfully above you

Than the threateningest star over Herculaneum.

My evil leaps

Like a wildcat from me.

And snaps at you.

But snatched away

From kisses' play

You reel

In the arms of wreath-crowned courtesans

Through their rose-scented zones'

Ecstatic song.

Hyenas slink at night

Hungrily about my dreams

Like brooding darknesses

In my tears' raging light.

AFTER-PAIN

Do you recall as I lay ill

So God-forlorn-

You came then;

It was Autumn still,

A sick wind through the streets was borne.

Two cold death's eyes

Would not have tortured me

Like your two sapphire eyes,

Those burning fairy tales. 
ELEGIE

Du warst mein Hyazinthentraum,

Bist heute noch mein süssestes Sehnen,

Aber mein Wünschen zittert durch Thränen

Und meine Hoffnung klagt vom Trauereschenbaum.

Tausend Wunschjahre lag ich vor Deinen Knieen, Meine Gedanken sprudelten wie junge Weine, Ein Venussehnen lag vor Deinen Knieen!

Zwei Sommer hielten wir uns schwer umfangen, Ich tauchte in den goldenen Strudel Deiner Schelmenlaunen

Bis aus den späten Nächten unsere Sterbeglocken klangen.

Und Neide schlichen heimlich, ihre Geil zu rächen, Die Wolken drohten wild wie schwarze Posaunen, Wir träumten beide einen Schmerzenstraum: Zwei böse Sterne fielen in derselben Nacht Und wir erblindeten in ihrem Stechen.

Der erste Blick, der uns zu eins gehämmert, Er quälte sich bis in die Morgenstunden, Bis weh das Herz des Ostens aufgedämmert.

Da sprangen alle grausigen Sagen auf,

Träumte nur noch Plagen,

Alle Plagen erdrosselten mich

Und reissende Hasse kamen

Und verheerten

Die Haine unserer jung gestorbenen Liebe.

Und wehrten meiner Seele Flucht zu Gott,

Gramjahre bebte ich hin,

Krankte zurück,

Kein Himmel beugte sich zu meinem Harme!

Durch alle Sümpfe schleift' ich mein verhungert Glück, Und warf mich müd dem Satan in die Arme. 
You were my hyacinthine dream.

Are still today my sweetest longing.

But my wish trembles through tears thronging, And my hope mourns from the weeping tree.

A thousand wish-years, I lay at your knees. My thoughts were bubbling like young wines. A Venus-longing lay before your knees!

Two summers long we held each other captive tight. I plunged in the golden whirlpool of your roguish whims Till late our death bells rang out of the night.

And envies sneaked in secret, to revenge their lust; The clouds were wildly threatening like black trombones; Both of us dreamed a dream of pain: In the same night two dread stars fell in flame And their sharp radiance blinded us.

The glance that hammered us first into one, It agonized into the morning hours Till, aching, the East's heart rose up in the dawn.

Then all the dreadful legends bounded up. I dreamed of merest misery. All the miseries strangled me, And rending hates appeared And ravaged

The groves of our love, which had died young. And barred my soul's escape to God;

Grief-years I shivered through, Sickened and fell back;

No heaven bent down to solace my alarm! Through all the swamps I dragged my starving joyAnd hurled myself exhausted into Satan's arm. 
VAGABU NDEN

$\mathrm{O}$, ich wollte in den Tag gehen, Alle Sonnen, alle Glutspiele fassen, Muss in trunk'ner Lenzluft untergeh'n

Tief in meinem Rätselblut.

Sehnte mich zu sehr nach dem Jubel!

Dass mein Leben verspiele mit dem Jubel.

Kaum noch fühlt' meine Seele den Goldsinn des Himmels,

Kaum noch sehen können meine Augen,

Wie müde Welle gleiten sie hin.

Und meine Sehnsucht taumelt wie eine sterbende Libelle.

Giesse Brand in mein Leben!

$\mathrm{Ja}$, ich irre mit Dir,

Durch alle Gassen wollen wir streifen,

Wenn unsere Seelen wie hungernde Hunde knurren.

An allen Höllen unsere Lüste schleifen,

Und sünd'ge Launen alle Teufel fleh'n

Und Wahnsinn werden uns're Frevel sein,

Wie bunte, grelle Abendlichter surren;

Irrsinnige Gedanken werden diese Lichte sein!

Ach Gott! Mir bangt vor meiner schwarzen Stunde,

Ich grabe meinen Kopf selbst in die Erde ein! 
VAGABONDS

Oh, I hoped to go into the day,

Seize all the suns, the play of fire;

I must go down in the drunk spring air,

Deep in my riddling blood.

Too much I yearned for jubilation!

That my life be played away in jubilation.

My soul can barely feel the golden sense of heaven still,

My eyes can barely see.

They roll on like exhausted waves,

And like a dying dragonfly my longing reels.

Pour fire into my life!

Yes, I'll go straying with you;

Let's roam through all the narrow streets,

When our souls growl like hungry dogs;

Let's whet our lusts in hellish heats,

And sinful whims implore all devils,

And our outrages will be quite deranged,

Buzzing like dazzling colored lights of eve.

These lights will be our thoughts' mad birth!

Oh God! But I'm afraid of my dark hour;

I'll bury my own head deep in the earth! 
DIE BEIDEN

Dem zuckte sein zackiges Augenbrau jäh Wie der Blitzstrahl einer Winternacht, Und jener mit dem süssen Weh, Dem ringenden Eden im Auge, Mit dem Himmelblond auf der Stirn. . . .

Ich senkte mich in Beide Wie ein erleuchtendes GestirnUnd es war, als sei ich:

Ihnen ihr Blut zu verraten:

Er mit dem scharfen Stahl im Aug' Träumte von Heldenthaten Im Dickicht meiner Urwaldaugen. Und jenem, dem die Höhen des Parnassos Mit Goldblicken winkten sternenwärts, Ihm spannte ich zwei meiner wilden, Ungezähmten Dürste ans Herz. 
THE TWO OF THEM

One's jagged eyebrow twitched abruptly Like lightning on a winter's eve;

And the other one did sweetly grieve,

With a grappling Eden in his eye,

With a blondness on his brow divine. . . .

Down I sank in them both

Like a constellation's shine-

And it seemed as if I were

Meant to betray to them their blood:

He with the gaze of sharpened steel

Dreamed of heroic knightlihood

In the brush of my jungle eyes.

And him, whom the Parnassian heights

With golden glances beckoned to starry parts,

To him I harnessed two of my untamed

Wild thirsts to drive his heart. 
MEINE BLUTANGST

Es war eine Ebbe in meinem Blut, Es schrie wie brüllende Ozeane Und mit meiner Seele wehte der Tod Wie mit einer Siegesfahne.

Zehn Könige standen um mein Bett, Zehn stolze, leuchtende Sterne, Sie tränkten mit Himmelsthau meine Qual, Alle Abende meine Erbqual.

Jäh rissen sich ihre Willen los, Wie schneidende Winterstürme.

Ueber die Herzen hinweg!

Ueber das Leben hinweg!

Und ihr rasender Mut wuchs Türme!

Und sie schlugen meine Blutangst tot, Wie Himmelsbrand blühte das Morgenrot, Und mein Blass schneite von ihren Wangen. 
THE FEAR DEEP IN MY BLOOD

There was an ebb tide in my blood;

It screamed like the bellowing sea.

And death was waving with my soul

Like a flag of victory.

Ten kings stood round about my bed, Ten proud and gleaming stars.

With heavenly dew they drenched my agony,

Each evening my ancestral agony.

Suddenly their wills tore away, Like piercing winter storms.

Over the hearts and away!

Over life and away!

Out of their wild courage towers formed!

And they struck my blood-fear dead;

Like fire in the heavens blossomed the morning red

And from their cheeks my pallor fell like snow. 
IM ANFANG

(Weltscherzo)

Hing an einer goldenen Lenzwolke,

Als die Welt noch Kind war, Und Gott noch junger Vater war.

Schaukelte, hei!

Auf dem Ätherei,

Und meine Wollhärchen flitterten ringelrei.

Neckte den wackelnden Mondgrosspapa,

Naschte Goldstaub der Sonnenmama,

In den Himmel sperrte ich Satan ein

Und Gott in die rauchende Hölle ein.

Die drohten mit ihrem grössten Finger

Und haben "klumbumm! klumbumm!» gemacht

Und es sausten die Peitschenwinde!

Doch Gott hat nachher zwei Donner gelacht

Mit dem Teufel über meine Todsünde.

Würde 10000 Erdglück geben,

Noch einmal so gottgeboren zu leben,

So gottgeborgen, so offenbar.

Ja! Ja!

Als ich noch Gottes Schlingel war!

S TYX

$\mathrm{O}$, ich wollte, daß ich wunschlos schlief,

Wüßt ich einen Strom, wie mein Leben so tief,

Flösse mit seinen Wassern. 
IN THE BEGINNING

(World Scherzo)

I hung on a golden cloud of spring

When the world was still a child, And God a young father still

Sat swinging, hey!

On the ether egg,

And my woolly hair all flitted a roundelay.

Teased the nodding moon-granddaddy,

Nibbled the gold dust of sun-mamá.

In Heaven I locked Satan in,

And God into smoking Hell I penned.

They threatened with their longest finger

And went: "Hurrump!" "Hurrump!" perhaps,

And the dashing winds came whipping!

But afterwards God laughed two thunderclaps

With the Devil about my mortal sin.

I'd give 10,000 earthly pleasures

To be once more so much God's treasure,

So safe in God, so free and wild.

Ah yes!

When I was still God's naughty child.

STYX

Oh, I wish that I could wishless sleep;

If I knew a stream that's like my life-so deep.

I'd flow with its waters. 
Hatte wogendes Nachthaar, Liegt lange schon wo begraben. Hatte Augen wie Bäche klar, Bevor die Trübsal mein Gast war, Hatte Hände muschelrotweiß, Aber die Arbeit verzehrte ihr Weiß. Und einmal kommt der Letzte, Der senkt den hohlen Blick Nach meines Leibes Vergänglichkeit Und wirft von mir alles Sterben. Und es atmet meine Seele auf Und trinkt das Ewige.

$\mathrm{Da}$ du Lenz gefühlt hast In meiner Winterhülle, $\mathrm{Da}$ du den Lenz erkannt hast In meiner TodstilleNicht wahr, das ist Gram Winter sein, eh der Sommer kam, Eh der Lenz sich ausgejauchzt hat.

$\mathrm{O}$, du! schenk mir deinen goldenen Tag Von deines Blutes blühendem Rot.

Meine Seele friert vor Hunger, Ist satt vom Reif-

$\mathrm{O}, \mathrm{du}$ ! Gieße dein Lenzblut Durch meine Starre, Durch meinen Scheintod. Sieh, ich harre Schon Ewigkeiten auf dich. 
Had billowing night-hair;

Lies long buried somewhere.

Had eyes like brooks, so clear,

Before affliction came to visit.

Had hands like shells of red and white.

But work devoured their white.

And some day the Last One will come;

He'll drop his hollow glance

Toward my body's evanescence,

And from me cast all death.

And then my soul will breathe relief

And drink the eternal.

SPRING SORROW

That you have felt the spring

Beneath my wintry sheath;

That you perceived the spring

In my repose of death-

That's grief-you'd say the same-

That winter's there before the summer came,

Before the spring's exulted to the full.

Ah, Dear! give me your golden day

Of your blood's flowering red.

My soul is freezing from its hunger,

Satiate with frost-

Ah, Dear! Pour in your springtime blood

Through my rigidity,

Through my dull look of death.

See, since eternity

I have been waiting for you. 
Deine Augen harren vor meinem Leben Wie Nächte, die sich nach Tagen sehnen, Und der schwüle Traum liegt auf ihnen unergründet.

Seltsame Sterne starren zur Erde, Eisenfarbene mit Sehnsuchtsschweifen, Mit brennenden Armen die Liebe suchen Und in die Kühle der Lüfte greifen.

SCHWARZE STERNE

Warum suchst du mich in unseren Nächten, In Wolken des Hasses auf bösen Sternen! Laß mich allein mit den Geistern fechten.

Sie schnellen vorbei auf Geyerschwingen Aus längst vergessenen Wildlandfernen. Eiswinde durch Lenzessingen.

Und du vergißt die Gärten der Sonne Und blickst gebannt in die Todestrübe. Ach, was irrst du hinter meiner Not. 
LOVE STARS

Your eyes are lingering before my life Like nights that long for days;

And sultry dreams lie on them, bottomless.

Most curious stars stare at the earth, Iron-colored, trailing tails of yearning. They reach into the coolness of the breeze And seek out love with arms of burning.

Why do you look for me in our nights, In clouds of hate upon wicked stars!

Leave me alone with the ghosts that I fight.

They come darting past me on vulture's wing, From lands long forgotten, wild and far. Ice-winds through the singing spring.

And you forget the gardens of the sun And, spellbound, stare at gloomy death.

Ah, why do you chase my miseries as they run. 
Schwere steigt aus allen Erden auf Und wir ersticken im Bleidunst, Jedoch die Sehnsucht reckt sich Und speit wie eine Feuersbrunst. Es tönt aus allen wilden Flüssen Das Urgeschrei, Evas Lied. Wir reißen uns die Hüllen ab, Vom Schall der Vorwelt hingerissen, Ich nackt! Du nackt!

Wilder, Eva, bekenne schweifender, Deine Sehnsucht war die Schlange, Ihre Stimme wand sich über deine Lippe, Und biß in den Saum deiner Wange.

Wilder, Eva, bekenne reißender, Den Tag, den du Gott abrangst, Da du zu früh das Licht sahst

Und in den blinden Kelch der Scham sankst.

Riesengroß

Steigt aus deinem Schoß

Zuerst wie Erfüllung zagend,

Dann sich ungestüm raffend, Sich selbst schaffend Gott-Seele. . . . . . .

Und sie wächst

Über die Welt hinaus,

Ihren Anfang verlierend,

Über alle Zeit hinaus,

Und zurück um dein Tausendherz

Ende überragend . . .

Singe, Eva, dein banges Lied einsam, Einsamer, tropfenschwer wie dein Herz schlägt, Löse die düstere Tränenschnur,

Die sich um den Nacken der Welt legt.

Wie das Mondlicht wandele dein Antlitz. . . .

Du bist schön. . . . 
A heaviness arises from all earths And we are strangling in a leaden haze, And yet old longing lifts its head And spews forth like a roaring blaze. There rings from all the rivers wild The primal cry, the song of Eve. We tear off every covering veil, By the primeval sound beguiled. I naked! You naked!

Wilder, Eve, confess more excessively How your longing was the snake; Its voice went winding across your lip And bit in the border of your cheek.

Wilder, Eve, confess more impetuously: You wrestled the day from God and overcame; When you too early saw the light And sank into the blinded cup of shame.

Vast in its size

From your womb does arise First like fulfillment hesitating,

Then gathering in rage, Itself creating God-soul. . . . . . . .

And it grows

Beyond the world, Lost to its start, Beyond all time,

And back around your marvelous heart Overtopping the end ...

Sing, Eve, your anxious song alone, Lonelier, heavy-dropped like the heartbeat's song. Loosen the gloomy string of tears That around the neck of the world is hung.

Change your countenance like moonlight. . . . You are very fair. . . . 
Singe, singe, horch, den Rauscheton,

Spielt die Nacht auf deinem Goldhaar schon:

"Ich trank atmende Süße

Vom schillernden Aste

Aus holden Dunkeldolden.

Ich fürchte mich nun

Vor meinem wachenden Blick-

Verstecke mich, du-

Denn meine wilde Pein

Wird Scham,

Verstecke mich, du,

Tief in das Auge der Nacht,

Daß mein Tag Nachtdunkel trage.

Dieses taube Getöse, das mich umwirrt!

Meine Angst rollt die Erdstufen herauf,

Düsterher, zu mir zurück, nachthin,

Kaum rastet eine Spanne zwischen uns.

Brich mir das glühende Eden von der Schulter!

Mit seinen kühlen Armen spielten wir,

Durch seine hellen Wolkenreife sprangen unsere Jubel.

Nun schnellen meine Zehe wie irre Pfeile über die Erde,

Und meine Sehnsucht kriecht in jähen Bogen mir voran.»

Eva, kehre um vor der letzten Hecke noch!

Wirf nicht Schatten mit dir,

Blühe aus, Verführerin.

Eva du heiße Lauscherin,

$\mathrm{O}$, du schaumweiße Traube,

Flüchte um vor der Spitze deiner schmalsten Wimper noch! 
Sing, sing, hear the rustling, hear,

The night already plays on your golden hair.

"I drank breathing sweetness

From the shimmering branch

Out of the fair dark flowers.

I am fearful now

Of my waking glance-

Conceal me, dear-

For my savage pain

Turns to shame.

Conceal me, dear,

Deep in night's eye,

So my day will bear the dark of night.

This deafening roar, pell-mell about me!

My fear rolls up the steps of the earth,

Gloomily hither-back to me-night-hence;

Hardly an inch remains between us.

Break off the glowing Eden from my shoulder!

We played with its cool arms;

Through its bright hoops of cloud our jubilations sprang.

Like crazy arrows now, my toes dart through the earth,

And my desire creeps on ahead in sudden curves."

Eve, turn back, before the final hedge!

Don't cast your shadows;

Quit flowering, seductress.

Eve, you hot hearkener,

O you grape-cluster, white as foam,

Turn and flee from the tip of your narrowest eyelash! 
Drei Stürme liebt ich ihn eher, wie er mich, Jäh schrien seine Lippen, Wie der geöffnete Erdmund! Und Gärten berauschten an Mairegen sich.

Und wir griffen unsere Hände, Die verlöteten wie Ringe sich; Und er sprang mit mir auf die Lüfte Gotthin, bis der Atem verstrich.

Dann kam ein leuchtender Sommertag, Wie eine glückselige Mutter, Und die Mädchen blickten schwärmerisch, Nur meine Seele lag müd und zag.

TRA U M

Der Schlaf entführte mich in deine Gärten, In deinen Traum-die Nacht war wolkenschwarz umwundenWie düstere Erden starrten deine Augenrunden, Und deine Blicke waren Härten-

Und zwischen uns lag eine weite, steife Tonlose Ebene . . . Und meine Sehnsucht, hingegebene, Küßt deinen Mund, die blassen Lippenstreife. 
FLIGHT OF LOVE

I loved him three storms earlier than he me;

His lips abruptly cried

Like the opening maw of earth!

And gardens became drunk on the rain of May.

And we seized each other's hands;

They were soldered shut like rings.

And he leaped with me on the winds,

Godwards, until our breath gave way.

Then came a luminous summer day

Much like a blissful mother,

And the girls stood gazing rapturously.

Only my soul was tired, and afraid to play.

DREAM

My sleep had kidnaped me into your gardens,

Into your dream - the night was wrapped in cloudy black-

Like gloomy earths your eye sockets stared back

And your glance hardened.

And there between us lay a wide and stiff,

A soundless plain ...

And my desire, surrendering to its pain,

Kisses your mouth, the pale line of your lips. 


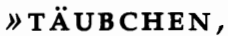

DAS IN SEINEM EIGNEN BLUTE SCHWIMMT"

Als ich also diese Worte an mich las,

Erinnerte ich mich

Tausend Jahre meiner.

Eisige Zeiten verschollen-Leben vom Leben,

Wo liegt mein Leben--

Und träumt nach meinem Leben.

Ich lag allen Tälern im Schoß,

Umklammerte alle Berge,

Aber nie meine Seele wärmte mich.

Mein Herz ist die tote Mutter,

Und meine Augen sind traurige Kinder,

Die über die Lande gehen.

"Täubchen, das in seinem eigenen Blute schwimmt". Ja, diese Worte an mich sind heiße Tropfen, Sind mein stilles Aufsterben

"Täubchen, das in seinem eigenen Blute schwimmt".

In den Nächten sitzen sieben weinende Stimmen

Auf der Stufe des dunklen Tors

Und harren.

Auf den Hecken sitzen sie

Um meine Träume

Und tönen.

Und mein braunes Auge blüht

Halberschlossen vor meinem Fenster

Und zirpt.-

"Täubchen, das in seinem eigenen Blute schwimmt". 
"DOVE THAT SWIMS IN ITS OWN BLOOD"

So when I read these words to me,

I recalled

A thousand years of mine.

Ages of ice now vanished-Life from all life,

Where lies my life-

And dreams of my life.

I lay in the womb of all valleys,

Clung to all mountains,

And yet my soul never kept me warm.

My heart is the dead mother,

And my eyes are unhappy children

Who walk across the lands.

"Dove that swims in its own blood."

Yes, these words about me are burning drops,

Are my silent dying-open:

"Dove that swims in its own blood."

In the nights sit seven weeping voices

On the stoop of the dark gate

And wait.

On the hedges they sit

Around my dreams

And sing.

And my brown eye blooms

Half-opened at the window

And chirps-

"Dove that swims in its own blood." 
EVA

Du hast deinen Kopf tief über mich gesenkt, Deinen Kopf mit den goldenen Lenzhaaren, Und deine Lippen sind von rosiger Seidenweichheit, Wie die Blüten der Bäume Edens waren.

Und die keimende Liebe ist meine Seele. $O$, meine Seele ist das vertriebene Sehnen, Du liebzitterst vor Ahnungen-

. . . Und weißt nicht, warum deine Träume stöhnen.

Und ich liege schwer auf deinem Leben, Eine tausendstämmige Erinnerung, Und du bist so blutjung, so adamjung . . . Du hast deinen Kopf tief über mich gesenkt-.

Aber fremde Tage hängen

Über uns mit kühlen Bläuen, Und weiße Wolkenschollen dräuen, Das goldene Strahleneiland zu verdrängen.

Auch wir beide sind besiegte Siegerinnen, Und Kronen steigen uns vom Blut der Zeder, Propheten waren unsere Väter, Unsere Mütter Königinnen.

Und süße Schwermutwolken ranken Sich über ihre Gräber lilaheiß in Liebeszeilen, Unsere Leiber ragen stolz, zwei goldene Säulen, Über das Abendland wie östliche Gedanken. 
EVE

You bent your head down very close to mine,

Your head with its golden hair of spring;

And your lips are of a rosy and silken softness

Like the buds that the trees of Eden bring.

And my soul is the upsprouting love.

$\mathrm{Oh}$, my soul is the banished longing.

You love-tremble with dark surmise-

.. . And don't know why your dreams lie moaning.

And I lie heavy on your life,

A memory with a thousand stems bestrung;

And you're so fresh, so Adam-young . . .

You bent your head down very close to mine.

OUR PROUD SONG

But alien days hang in suspense

Above us with their cool blues,

And white cloud-clods make threatening moves

To drive away the gold isle's radiance.

We two, too, are beaten victoresses;

From the blood of cedar our crowns arise;

Our fathers they made prophecies,

Our mothers were princesses.

And sweet clouds of melancholy stand

Over their graves hot-lilac in lines of love;

Proudly our bodies, two gold pillars, tower above

Like Eastern thoughts across the Evening Land. 
Unsere Arme schlingen sich entgegen

Durch das Leben in runden Schwingen,

Durch das Spiel von Feuerringen,

Zwei Äste sich durch Bogenwegen.

Unsere Seelen tragen scharfe Blüten

Und aus ihren Kelchen steigen

Weihedüfte . . . und die Himmel neigen

Ihre Häupter mit den blauen Güten.

Unsere Willen sind zwei harte Degen

Und sie haben nie verfehlt gestritten,

Und wir dringen bis zum Erzkreis vor, in seiner Mitten

Fällt nach dürren Ewigkeiten Freudenregen,

Alles Sehnen nieder, und vor unserm Schilde

Stürzt das blinde Dämmergraugebilde.

Unsere Adern schmettern wie Posaunen!

Unsere Augen blicken sich in Blicken,

Wie zwei Siege sich erblicken-

Und die Nacht des Tages voll in Lichterstaunen. 
OUR BATTLE SONG

Our arms go twining out toward one another

Through life in circling swings,

Through the game of fire rings,

Two branches through archways towards each other.

Our souls bloom with sharp flowers

And from their throats arise

Holy incense-and the skies

With goodnesses of blue their great heads lower.

Our wills are two hard swords,

And they have never fought in vain,

And we advance to the brazen circle, where joy's rain

In the midst after dry eternities has poured,

All longing downwards, and before our shields

The blind, gray twilight-figure yields.

Our arteries blare like trombones rent!

Our eyes glance at each other's glances,

Like two victories match glances-

And the day's night full in light-astonishment. 
Unter süßem Veilchenhimmel

Ist unsere Liebe aufgegangen,

Und ich suche allerwegen

Nach dir und deinen Morgenwangen.

Und den Ringelrangelhaaren

Rötlichblonden Rosenlocken,

Und den frühlingshellen Augen

Die so frischfreifrohfrohlocken.

Zwischen dicken Gummipflanzen

Lauern hinter Irdentöpfen

Strickpicknadelspitze Augen,

Tücksch aus bitteren Frauenköpfen.

$\mathrm{Daß}$ die beiden alten Damen

Hinter unsere Liebe kamen

Und dich in Gewahrsam nahmen,

Sind die Dramen unserer Herzen.

GROTESKE

Seine Ehehälfte sucht der Mond, Da sonst das Leben sich nicht lohnt.

Der Lenzschalk springt mit grünen Füßen, Ein Heuschreck über die Wiesen.

Steif steht im Teich die Schmackeduzie, Es sehnt und dehnt sich Fräulein Luzie. 
Under the sweet violet skies

Our love was born and grew, And I've been seeking everywhere Your cheeks of morn and you.

And your curly-whirly hair, Reddish-blondish roseate, And your springtime-brightened eyes That so joy-jump-jubilate.

Twixt the portly rubber plants Lurk behind ceramic vases Knit-pick-needle-pointed eyes, Spiteful in bitter women's faces.

That the two of those old ladies

Found out what we're thinking of And took you into custody, Are the dramas of our love.

GROTESQUE

The moon is looking for his better half; Without her life's not worth the gaff.

The spring's rogue jumps with feet of green, A grasshopper across the scene.

Within the pond stands stiff the smackaducy. Who widens in her longing? Fräulein Lucy. 
EVAS LIED

Die Luft ist von gährender Erde herb, Und der nackte Märzwald sehnt sich

Wie du-o, ich wollte, ich würde der Frühling,

Mit lauter Märchen umblühte ich dich.

Wäre meine Kraft nicht tot!

Ich hab all das Nachleid tragen müssen,

Und mein tagendes Herzrot

Ist von grollenden Himmeln zerrissen.

Und deine Sinne sind kühl,

Und deine Augen sind zwei Morgenfrühen,

Und das Blondgewirr auf deiner Stirn

Glüht, als ob Sonnen sie besprühen.

Aber du bist vertrieben wie ich,

Weil du auf das Land meiner Seele sankst,

Als das Glück des Erkenntnistags aus mir schrie Und seines Genießens Todangst. 
EVE'S SONG

Tart is the air from the earth's fermenting, And the naked March wood pines and pales

Like you-Oh, I wish I'd become the spring;

I'd flower around you with fairy tales.

If only my strength weren't dead!

All the after-pain I have had to bear,

And my dawning heart-red

The grumbling heavens rip and tear.

And your senses are cool,

And your eyes two mornings, early yet,

And that blond swirl there on your brow

Glows as if suns were spraying it.

But you are banished just like I;

For into the land of my soul you sank from sight

When the joy of my dawning knowledge burst in screams

And the deadly fear of its delight. 
MAIENREGEN

Du hast deine warme Seele

Um mein verwittertes Herz geschlungen,

Und all seine dunklen Töne

Sind wie ferne Donner verklungen.

Aber es kann nicht mehr jauchzen

Mit seiner wilden Wunde,

Und wunschlos in deinem Arme

Liegt mein Mund auf deinem Munde.

Und ich höre dich leise weinen,

Und es ist-die Nacht bewegt sich kaum-

Als fiele ein Maienregen

Auf meinen greisen Traum. 
MAY RAIN

You wrapped your warming soul

Around my weather-beaten heart;

And all its darker tones,

Far thunders, fade and part.

But it no longer can exult

With its wild injuries,

And, wishless in your arms,

My mouth on your mouth lies.

And I hear you softly weep

And it - the night but barely moves-might seem

As if a May rain fell

Upon my aging dream. 
Mein Herz ist eine traurige Zeit,

Die tonlos tickt.

Meine Mutter hatte goldene Flügel,

Die keine Welt fanden.

Horcht, mich sucht meine Mutter,

Lichte sind ihre Finger und ihre Füße wandernde Träume.

Und süße Wetter mit blauen Wehen

Wärmen meine Schlummer

Immer in den Nächten,

Deren Tage meiner Mutter Krone tragen.

Und ich trinke aus dem Monde stillen Wein,

Wenn die Nacht einsam kommt.

Meine Lieder trugen des Sommers Bläue

Und kehrten düster heim.

Verhöhnt habt ihr mir meine Lippe

Und redet mit ihr.

Doch ich griff nach euren Händen,

Denn meine Liebe ist ein Kind und wollte spielen.

Einen nahm ich von euch und den zweiten

Und küßte ihn,

Aber meine Blicke blieben rückwärts gerichtet

Meiner Seele zu.

Arm bin ich geworden

An eurer bettelnden Wohltat.

Und ich wußte nichts vom Kranksein,

Und bin krank von euch,

Und nichts ist diebischer als Kränke,

Sie bricht dem Leben die Füße,

Stiehlt dem Grabweg das Licht, Und verleumdet den Tod. 
MY QUIET SONG

(First Version)

My heart is a sad time

Tonelessly ticking.

My mother had golden wings

That found no world.

Listen! My mother's looking for me;

Her fingers are candles, her feet are wandering dreams.

And sweet weathers with blue winds

Warm my slumber

In the nights always

Whose days are wearing my mother's crown.

And from the moon I drink a quiet wine

When the night comes lonely.

My songs carried the summer's blue

And gloomily turned home.

Scorn you have shown my lip

And speak with it.

But I reached for your hands,

For my love is a child and wanted to play.

One of you I took and then the second

And kissed him.

But my gaze kept turning backward

Toward my soul.

I have become poor

From you begging benefaction.

I knew nothing of illness

And am ill from you.

And nothing's more thievish than illness;

It cripples the feet of life,

Steals light from the path of the grave

And slanders death. 


\author{
Aber mein Auge \\ Ist der Gipfel der Zeit, \\ Sein Leuchten küßt \\ Gottes Saum.
}

Und ich will euch noch mehr sagen,

Bevor es finster wird zwischen uns.

Bist du der Jüngste von euch,

So solltest du mein Ältestes wissen.

Auf deiner Seele werden es fortan

Alle Welten spielen.

Und die Nacht wird es wehklagen

Dem Tag.

Ich bin der Hieroglyph,

Der unter der Schöpfung steht.

Und ich artete mich nach euch,

Der Sehnsucht nach dem Menschen wegen.

Ich riß die ewigen Blicke von meinen Augen,

Das siegende Licht von meinen Lippen-

Weißt du einen schwereren Gefangenen,

Einen böseren Zauberer, denn ich.

Und meine Arme, die sich heben wollen,

Sinken... 
But my eye

Is the pinnacle of time;

Its radiance kisses

The hem of God.

And more, still, will I say to you

Before it turn dark between us.

If you there are the youngest one of you all

Then you should have my oldest wisdom.

From henceforth all the worlds

Will play it on your soul.

And the night will lament it

Unto the day.

I am the hieroglyph

Inscribed beneath creation.

And I assumed your ways

Out of a longing for human kind.

I tore the eternal glances from my eyes.

The light triumphant from my lips-

Do you know a more dangerous prisoner, A more evil sorcerer than I.

And my arms, that would lift up, Sink down ... 
MEIN LIEBESLIED

Wie ein heimlicher Brunnen

Murmelt mein Blut,

Immer von dir, immer von mir.

Unter dem taumelnden Mond

Tanzen meine nackten, suchenden Träume,

Nachtwandelnde Kinder,

Leise über düstere Hecken.

$\mathrm{O}$, deine Lippen sind sonnig . . .

Diese Rauschedüfte deiner Lippen . . .

Und aus blauen Dolden silberumringt

Lächelst du ... du, du.

Immer das schlängelnde Geriesel

Auf meiner Haut

Über die Schulter hinweg-

Ich lausche . . .

Wie ein heimlicher Brunnen

Murmelt mein Blut. 
MY LOVE SONG

My blood is a-murmur

Like a secret spring

Always of you. Always of me.

Under the staggering moon

My naked, searching dreams go dancing,

Somnambulant children,

Softly across gloomy hedges.

Oh, your lips are sunny . . .

This drugging fragrance of your lips . . .

And from blue flower clusters, silver-ringed,

You smile ... ah, you.

Always the serpentine rippling

Over my skin

Across the shoulder and on-

I am listening . . .

My blood is a-murmur

Like a secret spring. 
WE LTENDE

Es ist ein Weinen in der Welt, Als ob der liebe Gott gestorben wär, Und der bleierne Schatten, der niederfällt, Lastet grabesschwer.

Komm, wir wollen uns näher verbergen . . .

Das Leben liegt in aller Herzen

Wie in Särgen.

Du! wir wollen uns tief küssen-

Es pocht eine Sehnsucht an die Welt, An der wir sterben müssen.

\section{ANKUNFT}

Ich bin am Ziel meines Herzens angelangt.

Weiter führt kein Strahl.

Hinter mir laß ich die Welt, Fliegen die Sterne auf: Goldene Vögel.

Hißt der Mondturm die Dunkelheit. . . O, wie mich leise eine süße Weise betönt . . . Aber meine Schultern heben sich, hochmütige Kuppeln. 
There is a weeping in the world As if the Good Lord now lay dead, And, heavy as the grave, the weight Of the shadow falls like lead.

Come, let's go sneaking off then . . . In everybody's heart life lies As in a coffin.

Ah! Let's kiss deeply, you and IA longing's knocking at the world From which we'll surely die.

ARRIVA L

I have arrived at the goal of my heart.

No beam leads farther.

Behind me, I leave the world;

The stars go flying up: Gold birds.

The moon-tower hoists the darkness-

... Oh, how softly a sweet tune besounds me ...

But my shoulders are raised up, haughty domes. 
WO MAG DER TOD MEIN HERZ LASSEN?

Immer tragen wir Herz vom Herzen uns zu.

Pochende Nacht

Hält unsere Schwellen vereint.

Wo mag der Tod mein Herz lassen?

In einem Brunnen, der fremd rauscht-

In einem Garten, der steinern steht-

Er wird es in einen reißenden Fluß werfen.

Mir bangt vor der Nacht,

Daran kein Stern hängt.

Denn unzählige Sterne meines Herzens

Vergolden deinen Blutspiegel.

Liebe ist aus unserer Liebe vielfältig erblüht.

Wo mag der Tod mein Herz lassen? 
WHERE MIGHT DEATH LEAVE MY HEART?

We always bring each other heart of heart.

The knocking night

Keeps our thresholds joined.

Where might Death leave my heart?

In a spring that gushes strangely-

In a garden that stands like stone-

He'll throw it in a raging river.

I'm afraid of the night

On which no star is hung.

For my heart's numberless stars

Gild the mirror of your blood.

Love variously has blossomed from our love.

Where might Death leave my heart? 
Du nahmst dir alle Sterne

Über meinem Herzen.

Meine Gedanken kräuseln sich, Ich muß tanzen.

Immer tust du das, was mich aufschauen läßt, Mein Leben zu müden.

Ich kann den Abend nicht mehr Über die Hecken tragen.

Im Spiegel der Bäche Finde ich mein Bild nicht mehr.

Dem Erzengel hast du Die schwebenden Augen gestohlen;

Aber ich nasche vom Seim Ihrer Bläue.

Mein Herz geht langsam unter Ich weiß nicht wo-

Vielleicht in deiner Hand. Überall greift sie an mein Gewebe. 
You took for yourself all the stars

Above my heart.

My thoughts are curling;

I have to dance.

You're always doing something that makes me watch, Just to tire my life.

I cannot carry the evening Over the hedges any longer.

No more do I find my image In the mirror of the streams.

You've stolen the archangel's Floating eyes.

But I nibble on the honey Of their blueness.

My heart is slowly going down I don't know where-

Perhaps into your hand;

It snatches at my substance everywhere. 
Deine Seele, die die meine liebet, Ist verwirkt mit ihr im Teppichtibet.

Strahl in Strahl, verliebte Farben, Sterne, die sich himmellang umwarben.

Unsere Füße ruhen auf der Kostbarkeit, Maschentausendabertausendweit.

Süßer Lamasohn auf Moschuspflanzenthron, Wie lange küßt dein Mund den meinen wohl Und Wang die Wange buntgeknüpfte Zeiten schon.

ICH BIN TRAURIG

Deine Küsse dunkeln, auf meinem Mund.

Du hast mich nicht mehr lieb.

Und wie du kamst-!

Blau vor Paradies;

Um deinen süßesten Brunnen

Gaukelte mein Herz.

Nun will ich es schminken,

Wie die Freudenmädchen

Die welke Rose ihrer Lende röten.

Unsere Augen sind halb geschlossen, Wie sterbende Himmel-

Alt ist der Mond geworden.

Die Nacht wird nicht mehr wach.

Du erinnerst dich meiner kaum.

Wo soll ich mit meinem Herzen hin? 
Both my soul and yours, which loveth mine, In the Tibetan rug are intertwined.

Ray in ray, infatuated colors,

Stars that heaven-long wooed one another.

On this jewel our feet rest side by side Thousand-upon-thousand-meshèd wide.

Sweet Lama son upon a musk-plant throne, How long will your mouth likely kiss my own And cheek on cheek the brightly knotted times go on.

Your kisses darken upon my mouth.

You no longer love me.

And when you came-!

Blue from Paradise;

Around your sweetest fountain

My heart tricked and played.

Now I will paint it

Like the daughters of joy

Redden the withered rose of their loins.

Our eyes are halfway closed

Like dying skies-

The moon has become quite old.

No more will the night awaken.

You hardly remember me.

Where shall I turn with my heart? 
UND SUCHE GOTT

Ich habe immer vor dem Rauschen meines Herzens gelegen, Nie den Morgen gesehen,

Nie Gott gesucht.

Nun aber wandle ich um meines Kindes

Goldgedichtete Glieder

Und suche Gott.

Ich bin müde vom Schlummer, Weiß nur vom Antlitz der Nacht. Ich fürchte mich vor der Frühe, Sie hat ein Gesicht

Wie die Menschen, die fragen.

Ich habe immer vor dem Rauschen meines Herzens gelegen; Nun aber taste ich um meines Kindes

Gottgelichtete Glieder. 
AND LOOK FOR GOD

I always lay before my rushing heart, Never saw the morning,

Never sought God.

But now I wander about my child's

Gold-written limbs

And look for God.

I am weary from slumber;

Know of night's countenance only.

I'm afraid of the dawn;

It has a face

Like people with questions.

I always lay before my rushing heart;

But now I grope about my child's

God-lighted limbs. 
HEIM WEH

Ich kann die Sprache

Dieses kühlen Landes nicht, Und seinen Schritt nicht gehn.

Auch die Wolken, die vorbeiziehn, Weiß ich nicht zu deuten

Die Nacht ist eine Stiefkönigin.

Immer muß ich an die Pharaonenwälder denken.

Und küsse die Bilder meiner Sterne.

Meine Lippen leuchten schon

Und sprechen Fernes,

Und bin ein buntes Bilderbuch

Auf deinem Schoß.

Aber dein Antlitz spinnt

Einen Schleier aus Weinen.

Meinen schillernden Vögeln

Sind die Korallen ausgestochen,

An den Hecken der Gärten

Versteinern sich ihre weichen Nester.

Wer salbt meine toten Paläste-

Sie trugen die Kronen meiner Väter,

Ihre Gebete versanken im heiligen Fluß. 
I do not understand

The language of this cool land

And cannot keep its pace.

The clouds, too, floating by

I cannot explain.

The night is a step-queen.

I always have to think of the Pharaoh's forests

And kiss the pictures of my stars.

My lips already glow,

Speak distances.

And am a colored picture book

Upon your lap.

But your countenance spins

A veil made of weeping.

The corals are broken out

Of my shimmering birds.

In the hedges of gardens

Their soft nests turn to stone.

Who anoints my dead palaces-

They carried the crowns of my fathers;

Their prayers sank down in the holy stream. 
MEINE MUTTER

War sie der große Engel,

Der neben mir ging?

Oder liegt meine Mutter begraben

Unter dem Himmel von Rauch-

Nie blüht es blau über ihrem Tode.

Wenn meine Augen doch hell schienen

Und ihr Licht brächten.

Wäre mein Lächeln nicht versunken im Antlitz, Ich würde es über ihr Grab hängen.

Aber ich weiß einen Stern, Auf dem immer Tag ist;

Den will ich über ihre Erde tragen.

Ich werde jetzt immer ganz allein sein

Wie der große Engel,

Der neben mir ging. 
Was she the great angel

Who walked at my side?

Or does my mother lie buried

Under the sky of smoke-

No blue will ever bloom above her death.

If my eyes only shone with brightness

And brought her light.

Were my smile not sunk in my countenance, I'd hang it above her grave.

But I know a star

On which it is always day;

This will I carry over her earth.

I will always be quite alone now

Like the great angel

Who walked at my side. 
MARIE VON NAZARETH

Träume, säume, Marienmädchen-

Überall löscht der Rosenwind

Die schwarzen Sterne aus.

Wiege im Arme dein Seelchen.

Alle Kinder kommen auf Lämmern

Zottehotte geritten,

Gottlingchen sehen--

Und die vielen Schimmerblumen

An den Hecken-

Und den großen Himmel da

Im kurzen Blaukleide! 
MARY OF NAZARETH

Dream and tarry, Mary-maiden, Everywhere the wind of roses Quenches the black stars.

Rock in your arms your tiny soul.

All the children come on lambs

Riding giddy-up

To see little godlet-

And the many shimmering flowers

On the hedges-

And the arcing heavens there

In a short dress of blue! 
B A LL A DE

(Zweite Fassung)

Sascha kommt aus Sibirien heim;

Wie er aussehn mag?

Trotzendes Gold seine Stirne war,

Süßer Todstrahl sein Haar,

Seine Lippen brannten am Altar.

Sascha trank meinen Herzseim

Jede Nacht, die am Traumhang lag.

Was er sagen mag-

Wie er klagen mag-

Wo steck ich meinen Liebsten hin?

Da ich ihm untreu war

Und doch nur seine Blume bin.

Dem Dichter färbt er die Schläfe rot,

Seine Ehre sticht den Wilddieb tot.

Aber den König trifft er nicht, Der hat meines Bruders steinern Gesicht.

Sascha! 
B A L L A D

(Second Version)

Sascha comes back from Siberia.

What will he look like?

His brow was threatening gold,

His hair a sweet death-ray,

His lips burned on the altar.

Sascha drank my honey-heart

Each night on the hill of dream.

What he will say-

How he'll inveigh-

Where shall I put my dearest one?

Since I was untrue,

And yet I am his flower only.

He dyes the poet's temples red;

His honor stabs the poacher dead.

But he doesn't strike the king a blow;

$\mathrm{He}$ has my brother's stony brow.

Sascha! 
MEIN LIEBESLIED

Auf deinen Wangen liegen

Goldene Tauben.

Aber dein Herz ist ein Wirbelwind,

Dein Blut rauscht, wie mein Blut-

Süß

An Himbeersträuchern vorbei.

$\mathrm{O}$, ich denke an dich-

Die Nacht frage nur.

Niemand kann so schön

Mit deinen Händen spielen,

Schlösser bauen, wie ich

Aus Goldfinger;

Burgen mit hohen Türmen!

Strandräuber sind wir dann.

Wenn du da bist,

Bin ich immer reich.

Du nimmst mich so zu dir,

Ich sehe dein Herz sternen.

Schillernde Eidechsen

Sind deine Geweide.

Du bist ganz aus Gold-

Alle Lippen halten den Atem an. 
MY LOVE SONG

Golden doves

Brood upon your cheeks.

But your heart is a whirlwind;

Your blood rushes like my blood-

Sweetly

Past the raspberry bushes.

Oh, I think of you-

Just ask the night.

No one else can play

So nicely with your hands.

Build palaces, like me,

Out of ring finger.

Castles with tall towers!

We're pirates at the beach.

When you are here

I am always rich.

You take me to you so,

I see your heart turn star.

Your entrails are

Lizards of irridescent light.

You are entire of gold-

All lips stop breathing. 
EIN LIEBESLIED

Aus goldenem Odem

Erschufen uns Himmel.

$\mathrm{O}$, wie wir uns lieben . . .

Vögel werden Knospen an den Ästen,

Und Rosen flattern auf.

Immer suche ich nach deinen Lippen

Hinter tausend Küssen.

Eine Nacht aus Gold,

Sterne aus Nacht . . .

Niemand sieht uns.

Kommt das Licht mit dem Grün, Schlummern wir;

Nur unsere Schultern spielen noch wie Falter. 
A LOVE SONG

Of golden breath

The heavens shaped us.

Oh, how we love each other . . .

Birds become buds on the branches,

And roses flutter up.

I'm always looking for your lips

Behind a thousand kisses.

A night of gold,

Stars made of night ...

Nobody sees us.

When the light comes up with the green

We're slumbering;

Only our shoulders play like butterflies. 
EIN LIED DER LIEBE

Seit du nicht da bist, Ist die Stadt dunkel.

Ich sammle die Schatten

Der Palmen auf,

Darunter du wandeltest.

Immer muß ich eine Melodie summen,

Die hängt lächelnd an den Ästen.

Du liebst mich wieder-

Wem soll ich mein Entzücken sagen?

Einer Waise oder einem Hochzeitler,

Der im Widerhall das Glück hört.

Ich weiß immer,

Wann du an mich denkst-

Dann wird mein Herz ein Kind

Und schreit.

An jedem Tor der Straße

Verweile ich und träume;

Ich helfe der Sonne deine Schönheit malen

An allen Wänden der Häuser.

Aber ich magere

An deinem Bilde.

Um schlanke Säulen schlinge ich mich

Bis sie schwanken.

Überall steht Wildedel, Die Blüten unseres Blutes.

Wir tauchen in heilige Moose,

Die aus der Wolle goldener Lämmer sind.

Wenn doch ein Tiger

Seinen Leib streckte 
A SONG OF LOVE

Since you have been gone

The city is dark.

I pick up the shadows

Of the palms

By which you wandered.

I always have to hum a melody;

It hangs there, smiling, in the branches.

You love me again-

To whom shall I tell my rapture?

To an orphan girl or a bridegroom

Who, in the echo, hears happiness.

I always know

When you think of me.

Then my heart becomes a child And cries.

At every gate of the street

I stop and dream.

I help the sun to paint your beauty

On all the walls of the houses.

But I grow lean

On your image.

I twine myself around slender pillars

Until they sway.

Everywhere stands noblewild, The blossoms of our blood.

We plunge into holy mosses

Which are made of the wool of golden lambs.

If only a tiger

Would stretch his body 
Über die Ferne, die uns trennt, Wie zu einem nahen Stern.

Auf meinem Angesicht Liegt früh dein Hauch.

S ASCHA

Um deine Lippen blüht noch jung

Der Trotz dunkelrot,

Aber auf deiner Stirne sind meine Gebete

Vom Sturm verwittert.

$\mathrm{Da}$ wir uns im Leben

Nie küssen sollten . . .

Nun bist du der Engel,

Der auf meinem Grab steht.

Das Atmen der Erde bewegt

Meinen Leib wie lebendig.

Mein Herz scheint hell

Vom Rosenblut der Hecken.

Aber ich bin tot, Sascha,

Und das Lächeln liegt abgepflückt

Nur noch kurz auf meinem Gesicht. 
Over the distance that divides us,

Like to a near star.

Upon my countenance

You breathe betimes.

SASCHA

Young defiance blooms yet

Dark red around your lips.

On your brow my prayers are

Beaten by the storm.

Strange that we never kissed

Our whole life long . . .

Now you are the angel

Who's standing on my grave.

The earth's breath stirs

My body, as if alive.

My heart shines bright

From the rose blood of the hedge.

But, Sascha, I am dead, And my smile has been plucked off

And lies just a brief time still upon my face. 
SENNA HOY

Seit du begraben liegst auf dem Hügel, Ist die Erde süß.

Wo ich hingehe nun auf Zehen,

Wandele ich über reine Wege.

$O$ deines Blutes Rosen

Durchtränken sanft den Tod.

Ich habe keine Furcht mehr

Vor dem Sterben.

Auf deinem Grabe blühe ich schon

Mit den Blumen der Schlingpflanzen.

Deine Lippen haben mich immer gerufen, Nun weiß mein Name nicht mehr zurück.

Jede Schaufel Erde, die dich barg, Verschüttete auch mich.

Darum ist immer Nacht an mir, Und Sterne schon in der Dämmerung.

Und ich bin unbegreiflich unseren Freunden Und ganz fremd geworden.

Aber du stehst am Tor der stillsten Stadt Und wartest auf mich, du Großengel. 
SENNA HOY

Since you've been lying buried on the hill The earth is sweet.

Wherever I go on tiptoe now

I wander immaculate ways.

Oh the roses of your blood

Softly drench death through.

No longer do I feel

The fear of dying.

Upon your grave I bloom

With the flowers of vines.

Your lips called to me always,

Now my name finds no way back.

Every shovel of earth that hid you

Buried me also.

Therefore night is in me always, And stars already in the twilight.

And I am incomprehensible to our friends And become a stranger.

But you stand at the gate of the stillest city, And wait for me, Great Angel. 
HANS EHRENBAUM-DEGELE

Er war der Ritter in Goldrüstung.

Sein Herz ging auf sieben Rubinen.

Darum trugen seine Tage

Den lauteren Sonntagsglanz.

Sein Leben war ein lyrisches Gedicht,

Die Kriegsballade sein Tod.

Er sang den Frauen Lieder

In süßerlei Abendfarben.

Goldnelken waren seine Augen,

Manchmal stand Tau in ihnen.

Einmal sagte er zu mir:

»ch muß früh sterben."

Da weinten wir beide

Wie nach seinem Begräbnis.

Seitdem lagen seine Hände

Oft in den meinen.

Immer hab ich sie gestreichelt,

Bis sie die Waffe ergriffen. 
He was the knight in gold armor.

His heart ran on seven rubies.

That's why his days conveyed

The perfect Sunday splendor.

His life was a lyric poem, The ballad of war his death.

Songs he sang to the women In sweet kinds of evening colors.

And gold carnations were his eyes, Sometimes with dew upon them.

One day he told me:

"I'll surely die young."

Then we both wept together As if at his funeral.

Ever since that his hands

Lay often in mine.

I always caressed them

Till they reached for the gun. 
AN DEN RITTER AUS GOLD

Du bist alles was aus Gold ist

In der großen Welt.

Ich suche deine Sterne

Und will nicht schlafen.

Wir wollen uns hinter Hecken legen,

Uns niemehr aufrichten.

Aus unseren Händen

Süße Träumerei küssen.

Mein Herz holt sich

Von deinem Munde Rosen.

Meine Augen lieben dich an,

Du haschst nach ihren Faltern.

Was soll ich tun,

Wenn du nicht da bist.

Von meinen Lidern

Tropft schwarzer Schnee;

Wenn ich tot bin,

Spiele du mit meiner Seele. 
TO THE KNIGHT OF GOLD

You are everything that is gold In the great world.

I seek your stars

And have no wish to sleep.

Let us lie down behind hedges, Never rise up again.

Out of our hands

Let's kiss sweet reveries.

My heart fetches

Roses from your mouth.

My eyes look love at you;

You snatch at their butterflies.

What shall I do

When you're not here.

From my lids

Drips black snow.

When I am dead:

Please play with my soul. 
O, DEINE HÄNDE

Sind meine Kinder.

Alle meine Spielsachen

Liegen in ihren Gruben.

Immer spiel ich Soldaten

Mit deinen Fingern, kleine Reiter,

Bis sie umfallen.

Wie ich sie liebe

Deine Bubenhände, die zwei. 
OH, YOUR HANDS

Are my children.

All of my playthings

Lie in their hollows.

I always play soldiers

With your fingers, little riders,

Till they fall down.

How I do love them,

The two of them, your boy's hands. 
GISELHEER DEM HEIDEN

Ich weine-

Meine Träume fallen in die Welt.

In meine Dunkelheit

Wagt sich kein Hirte.

Meine Augen zeigen nicht den Weg

Wie die Sterne.

Immer bettle ich vor deiner Seele;

Weißt du das?

Wär ich doch blind-

Dächte dann, ich läg in deinem Leib.

Alle Blüten täte ich

$\mathrm{Zu}$ deinem Blut.

Ich bin vielreich,

Niemandwer kann mich pflücken;

Oder meine Gaben tragen

Heim.

Ich will dich ganz zart mich lehren;

Schon weißt du mich zu nennen.

Sieh meine Farben,

Schwarz und stern

Und mag den kühlen Tag nicht,

Der hat ein Glasauge.

Alles ist tot,

Nur du und ich nicht. 
TO GISELHEER THE HEATHEN

I weep-

My dreams fall into the world.

Into my darkness

No shepherd dares to come.

My eyes do not point the way

Like stars.

I'm always begging from your soul;

Are you aware?

Were I only blind-

I'd think I was lying in your body.

All blossoms would I add

Unto your blood.

I am muchly rich;

No anybody can pluck me;

Or carry my gifts

Home.

I'll teach me to you quite gently;

Already you know what I'm called.

Look at my colors,

Black and star.

And I don't like the cool day;

It has a glass eye.

Everything's dead

Except you and me. 
Ich hab in deinem Antlitz

Meinen Sternenhimmel ausgeträumt.

Alle meine bunten Kosenamen

Gab ich dir,

Und legte die Hand

Unter deinen Schritt,

Als ob ich dafür

Ins Jenseits käme.

Immer weint nun

Vom Himmel deine Mutter,

Da ich mich schnitzte

Aus deinem Herzfleische,

Und du so viel Liebe

Launisch verstießest.

Dunkel ist es-

Es flackert nur noch

Das Licht meiner Seele. 
PURE DIAMOND

I've finished dreaming in your face About my starry sky.

All of my colorful pet names

I gave to you.

And laid my hand

Beneath your foot

As if for that

I'd get to Heaven.

Now from Beyond

Your mother is weeping still,

Since I carved myself

From your heart's flesh,

And peevishly

You turned down so much love.

It's dark-

The only flickering still

Is the light of my soul. 
DAS LIED DES SPIELPRINZEN

Wie kann ich dich mehr noch lieben?

Ich sehe den Tieren und Blumen

Bei der Liebe zu.

Küssen sich zwei Sterne,

Oder bilden Wolken ein Bild-

Wir spielten es schon zarter.

Und deine harte Stirne,

Ich kann mich so recht an sie lehnen,

Sitz drauf wie auf einem Giebel.

Und in deines Kinnes Grube

Bau ich mir ein Raubnest-

Bis-du mich aufgefressen hast.

Find dann einmal morgens

Nur noch meine Kniee,

Zwei gelbe Skarabäen für eines Kaisers Ring. 
THE SONG OF THE PLAYMATE PRINCE

How can I love you even more?

I watch the flowers and animals

At their love.

If two stars kiss,

Or if clouds form a picture-

We've already played it more gently still.

And your hard brow,

I can really lean myself against it,

Sit on it like on a gable.

And in the hollow of your chin

I build a robber's hideaway-

Until-you've eaten me all up.

Find then one fine morning

Only my knees left over,

Two yellow scarabs for an emperor's ring. 
HINTER B ÄUMEN BERG ICH MICH

Bis meine Augen ausgeregnet haben,

Und halte sie tief verschlossen,

Daß niemand dein Bild schaut.

Ich schlang meine Arme um dich

Wie Gerank.

Bin doch mit dir verwachsen,

Warum reißt du mich von dir?

Ich schenkte dir die Blüte

Meines Leibes,

Alle meine Schmetterlinge

Scheuchte ich in deinen Garten.

Immer ging ich durch Granaten.

Sah durch dein Blut

Die Welt überall brennen

Vor Liebe.

Nun aber schlage ich mit meiner Stirn

Meine Tempelwände düster.

O du falscher Gaukler,

Du spanntest ein loses Seil.

Wie kalt mir alle Grüße sind,

Mein Herz liegt bloß,

Mein rot Fahrzeug

Pocht grausig.

Bin immer auf See

Und lande nicht mehr. 
Until my eyes are rained out dry,

And keep them locked up tight

So nobody sees your picture.

I twisted my arms around you

Like long vines.

I'm grown to you after all;

Why do you tear me from you?

I gave you the budding

Of my body;

Shooed all my butterflies

Into your garden.

I walked and walked through the pomegranate trees,

Saw through your blood

The world burning everywhere

From love.

But now with my brow I beat

Dismally the walls of my temples.

O you false trickster,

You strung a loose rope.

How cold all greetings seem to me;

My heart lies bare.

My red vehicle

Knocks dreadfully.

I am always at sea

And land no longer. 
GISELHEER DEM TIGER

Über dein Gesicht schleichen die Dschungeln.

$\mathrm{O}$, wie du bist!

Deine Tigeraugen sind süß geworden

In der Sonne.

Ich trag dich immer herum

Zwischen meinen Zähnen.

Du mein Indianerbuch,

Wild West,

Siouxhäuptling!

Im Zwielicht schmachte ich

Gebunden am Buxbaumstamm-

Ich kann nicht mehr sein

Ohne das Skalpspiel.

Rote Küsse malen deine Messer

Auf meine Brust-

Bis mein Haar an deinem Gürtel flattert. 
TO GISELHEER THE TIGER

The jungles creep across your face.

Oh, how you are!

Your tiger's eyes have sweetened

In the sun.

I'm carrying you around

Between my teeth.

You, my Indian book,

Wild West,

Sioux chief!

I languish in the twilight

Lashed to a boxwood tree-

I can't get along any more

Without the scalp game.

Your knives draw red kisses

On my breast-

Until my hair is fluttering on your belt. 
O GOTT

Überall nur kurzer Schlaf

Im Mensch, im Grün, im Kelch der Winde.

Jeder kehrt in sein totes Herz heim.

-Ich wollt die Welt wär noch ein Kind-

Und wüßte mir vom ersten Atem zu erzählen.

Früher war eine große Frömmigkeit am Himmel,

Gaben sich die Sterne die Bibel zu lesen.

Könnte ich einmal Gottes Hand fassen

Oder den Mond an seinem Finger sehn.

O Gott, o Gott, wie weit bin ich von dir!

HÖRE

Ich raube in den Nächten

Die Rosen deines Mundes,

Daß keine Weibin Trinken findet.

Die dich umarmt,

Stiehlt mir von meinen Schauern,

Die ich um deine Glieder malte.

Ich bin dein Wegrand.

Die dich streift,

Stürzt ab.

Fühlst du mein Lebtum

Überall

Wie ferner Saum? 
O GOD

Only a brief sleep everywhere

In man, in the green, in the cup of the winds.

Everyone goes home to his dead heart.

-I wish the world were still a child-

And was able to tell me how it first drew breath.

One time there was great piety in heaven;

The stars passed the Bible around to read.

If only I could take God's hand sometime

Or see on his finger the spinning moon.

O God, O God, how far I am from you!

L IS TEN

I steal at night

The roses of your mouth,

So no she-woman will find drink.

She that hugs you

Robs me of my shuddering

Which I painted around your limbs.

I am your road's edge.

She that skirts you

Plunges down.

Do you feel my lifedom

Everywhere

Like a distant rim? 
Ich denke immer ans Sterben, Mich hat niemand lieb.

Ich wollt ich wär still Heiligenbild Und alles in mir ausgelöscht.

Träumerisch färbte Abendrot Meine Augen wund verweint.

Weiß nicht wo ich hin soll Wie überall zu dir.

Bist meine heimliche Heimat Und will nichts Leiseres mehr.

Wie blühte ich gern süß empor An deinem Herzen himmelblauLauter weiche Wege Legte ich um dein pochend Haus. 
TURNED INWARD

I think of dying all the time;

Nobody loves me.

I wish I were a quiet icon

And everything extinguished in me.

The dreamy sundown red would dye

My eyes all sore from crying.

I don't know where to turn to,

Except everywhere to you.

You're my secret homeland,

And I want nothing quieter.

How glad I'd be to sweetly flower

Up around your sky-blue heart-

Many a soft path I laid

About your throbbing house. 
NUR DICH

Der Himmel trägt im Wolkengürtel

Den gebogenen Mond.

Unter dem Sichelbild

Will ich in deiner Hand ruhn.

Immer muß ich wie der Sturm will, Bin ein Meer ohne Strand.

Aber seit du meine Muscheln suchst, Leuchtet mein Herz.

Das liegt auf meinem Grund Verzaubert.

Vielleicht ist mein Herz, die Welt,

Pocht-

Und sucht nur noch dich-

Wie soll ich dich rufen? 
ONLY FOR YOU

The sky wears in a belt of clouds

The bended moon.

Under the sickle image

I want to rest within your hand.

I always have to do the will of the storm;

Am a sea without shore.

But since you seek my seashells

My heart glows.

It lies at the bottom of me

Under a spell.

Perhaps my heart is the world,

Beats-

And searches only for you-

How should I call you? 
Deine rauhen Blutstropfen

Süßen auf meiner Haut.

Nenne meine Augen nicht Verräterinnen,

Da sie deine Himmel umschweben;

Ich lehne lächelnd an deiner Nacht

Und lehre deine Sterne spielen.

Und trete singend durch das rostige Tor

Deiner Seligkeit.

Ich liebe dich und nahe weiß

Und verklärt auf Wallfahrtzehen.

Trage dein hochmütiges Herz,

Den reinen Kelch den Engeln entgegen.

Ich liebe dich wie nach dem Tode

Und meine Seele liegt über dich gebreitet-

Meine Seele fing alle Leiden auf,

Dich erschüttern ihre schmerzlichen Bilder.
Aber so viele Rosen blühen,
Die ich dir schenken will;
$\mathrm{O}$, ich möchte dir alle Gärten bringen
In einem Kranz.
Immer denke ich an dich,
Bis die Wolken sinken;
Wir wollen uns küssen-
Nicht? 
Your blood's rough drops Are sweetening on my flesh.

Don't call my eyes traitoresses, Since they float around your skies.

Smiling I lean upon your night And teach your stars to play.

And enter singing the rusty gate Of your blissfulness.

I love you and come near

White and transfigured on pilgrim's toes.

Carry your proud heart,

Pure chalice, towards the angels.

I love you as after death

And my soul lies spread upon you-

My soul caught up all sorrows;

You're shaken by its painful images.

But so many roses flower

That I want to give you;

Oh, I'd like to bring you all my gardens In one wreath.

Always I think of you Till the clouds descend;

Let's kiss each otherYes? 
DEM BARBAREN

Ich liege in den Nächten Auf deinem Angesicht.

Auf deines Leibes Steppe Pflanze ich Zedern und Mandelbäume.

Ich wühle in deiner Brust unermüdlich Nach den goldenen Freuden Pharaos.

Aber deine Lippen sind schwer, Meine Wunder erlösen sie nicht.

Hebe doch deine Schneehimmel

Von meiner Seele-

Deine diamantnen Träume

Schneiden meine Adern auf.

Ich bin Joseph und trage einen süßen Gürtel Um meine bunte Haut.

Dich beglückt das erschrockene Rauschen Meiner Muscheln.

Aber dein Herz läßt keine Meere mehr ein. O du! 
TO THE BARBARIAN

I lie in the nights

Upon your countenance,

On the steppes of your body

Plant cedars and almond trees.

Ceaselessly I rummage in your breast For the Pharaoh's golden joys.

But your lips are hard;

My miracles don't redeem them.

Please lift your snow-filled skies

From off my soul-

Your diamond dreams

Cut open my arteries.

I am Joseph and wear a sweet girdle About my bright skin.

My seashells' frightened roar

Enraptures you.

But your heart lets no more oceans in.

O you! 
DEM HERZOG VON LEIPZIG

Deine Augen sind gestorben;

Du warst so lange auf dem Meer.

Aber aueh ich bin

Ohne Strand.

Meine Stirne ist aus Muschel.

Tang und Seestern hängen an mir.

Einmal möchte ich mit meiner ziellosen Hand

Über dein Gesicht fassen,

Oder eine Eidechse über deine Lippen

Liebentlang mich kräuseln.

Weihrauch strömt aus deiner Haut,

Und ich will dich feiern,

Dir bringen meine Gärten,

Überall blüht mein Herz bunt auf. 
TO THE DUKE OF LEIPZIG

Your eyes have died;

You were so long at sea.

But I too am

Without a beach.

My forehead is made of mussel shell.

Sea-tang and starfish are hanging on me.

I'd like sometime with an aimless hand

To feel across your face,

Or, a lizard across your lips,

Curl myself love-along.

Incense rises from your skin, And I would celebrate you,

Bring to you my gardens;

My heart opens everywhere in bright bloom. 
ABER DEINE BRAUEN SIND UNWETTER

In der Nacht schweb ich ruhlos am Himmel

Und werde nicht dunkel vom Schlaf.

Um mein Herz schwirren Träume

Und wollen Süßigkeit.

Ich habe lauter Zacken an den Randen, Nur du trinkst Gold unversehrt.

Ich bin ein Stern

In der blauen Wolke deines Angesichts.

Wenn mein Glanz in deinem Auge spielt, Sind wir eine Welt.

Und würden entschlummern verzücktAber deine Brauen sind Unwetter.

DU MACHST MICH TRAURIG-HÖR

Bin so müde.

Alle Nächte trag ich auf dem Rücken

Auch deine Nacht,

Die du so schwer umträumst.

Hast du mich lieb?

Ich blies dir arge Wolken von der Stirn

Und tat ihr blau.

Was tust du mir in meiner Todesstunde? 
At night I hover restless in the heavens And don't become dark with sleep.

Dreams whir around my heart Desiring sweetness.

I am covered with sharp points along the edges;

You alone drink gold unharmed.

I am a star

In the blue cloud of your face.

When in your eye my splendor plays

We are one world.

And would fall into rapturous slumber-

But your brows are a storm.

YOU MAKE ME SAD-LISTEN

Am so tired.

I carry all the nights upon my back

Your night too,

That you wrap in such thick dreams.

Do you love me?

I blew some wicked clouds off of your brow And made it blue.

What will you do for me in my hour of death? 
DEM KÖNIG VON BÖHMEN

Ich frage nicht mehr-

Ich weiß wer auf den Sternen wohnt.

Mein Herz sinkt tief in die Nacht.

So sterben Liebende

Immer an zärtlichen Himmeln vorbei;

Und atmen wieder dem Morgen entgegen

Auf frühleisen Schweben.

Ich aber wandele mit den heimkehrenden Sternen.

Und ich habe viele schlafende Knospen ausgelöscht, Will ihr Sterben nicht sehn,

Wenn die Rosenhimmel tanzen.

Aus dem Gold meiner Stirne leuchtet der Smaragd,

Der den Sommer färbt.

Ich bin eine Prinzessin.

Mein Herz sinkt tief in die Nacht

An Liebende vorbei. 
TO THE KING OF BOHEMIA

I no longer ask-

I know who lives on the stars.

My heart sinks deep into the night.

Thus lovers die

On and on past gentle heavens.

And breathe again towards the morning

On softly early wings.

But I am wandering with the homeward stars.

And I have extinguished many sleeping buds;

Don't want to see their dying

When the rosy heavens dance.

From the gold of my brow the emerald gleams That tints the summer.

I am a princess.

My heart sinks deep into the night

On past the lovers. 
DEM DANIEL JESUS PAUL

Du es ist Nacht-

Wir wollen unsere Sehnsucht teilen, Und in die Goldgebilde blicken.

Vor meinem Herzen sitzt immer eine Tote Und bettelt um Almosen.

Und summt meine Lieder

Schon einen weißgewordenen Sommer lang.

Über den Grabweg hinweg

Wollen wir uns lieben,

Tollkühne Knaben,

Könige, die sich nur mit dem Szepter berühren!

Frage nicht-ich lausche

Deiner Augen Rauschehonig.

Die Nacht ist eine weiche Rose,

Wir wollen uns in ihren Kelch legen,

Immer ferner versinken, Ich bin müde vom Tod! 
TO DANIEL JESUS PAUL

Look, it is night-

Let us share our longing

And gaze into the shapes of gold.

A dead woman's always sitting by my heart

Begging for alms.

And hums my songs

The whole white summer long.

Let us love one another

Across the grave path and beyond,

Bold, brash boys,

Kings, who touch one another with scepters only.

Don't ask-I'm listening

To the drunken honey of your eyes.

The night is a soft rose;

Let us lie down in its cup,

Sink further and further;

I am tired of death! 
ABSCHIED

Aber du kamst nie mit dem AbendIch saß im Sternenmantel.

... Wenn es an mein Haus pochte, War es mein eigenes Herz.

Das hängt nun an jedem Türpfosten, Auch an deiner Tür;

Zwischen Farren verlöschende Feuerrose Im Braun der Guirlande.

Ich färbte dir den Himmel brombeer Mit meinem Herzblut.

Aber du kamst nie mit dem Abend... Ich stand in goldenen Schuhen. 
LEAVE - T AKING

But you never came with the eveningI sat in a robe of stars.

.. When there was a knock at the door It was only my own heart.

This hangs now on every doorpost, On your door too.

Between ferns, expiring fire-roses In the brown of the garland.

I colored the heavens blackberry for you With my heart's blood.

But you never came with the evening... I stood there in golden shoes. 
Wie Perlen hängen seine Bilder

Schaumleicht an seidenen Wänden aufgereiht.

Mit goldenem Harz der Hagebutten

Und Rosenseime,

Malt er der Prinzen Liebeskleid.

Um ihren zarten Schultern tragen sie An Ketten-Souvenir-im Medaillon Verzückt des Freundes Paradeis.

Und ihre Hände spielen mit den Bächen

Und feinen Blumenstengeln

Und dem jungen Reis.

Und necken gern den Ziegenbock.

Glasäugig lauscht die graue Geiß.

Und ihre Leiber lieben sich

Wie süßgeblühte Bohnenstöcke,

Die sich bewegen kaum in ihrer Adeligkeit. 
His pictures hang like pearls

As light as foam, in rows on silken walls.

With golden resin of haws

And honey of rose

He paints the love-dress of the princes.

Around their delicate shoulders they are wearing

On chains-a souvenir-inside a locket, Rapturously, their friend's paradise.

And their hands play with the streams

And the fine stems of flowers

And the young branch.

And like to tease the bearded goat.

Glassy-eyed the she-goat listens.

And their bodies love each other

Like bean poles in sweet bloom

That hardly move in their gentility. 
Unter der Wehmut der Esche

Lächeln die Augen meiner Freundin.

Und ich muß weinen

Überall wo Rosen aufblühn.

Wir hören beide unseren Namen nicht-

Immer Nachtwandlerinnen zwischen den bunten Jünglingen.

Meine Freundin gaukelt mit dem Mond,

Unserm Sternenspiel folgen Erschrockene nach.

O, unsere Schwärmerei berauscht

Die Straßen und Plätze der Stadt.

Alle Träume lauschen gebannt hinter den Hecken

Kann nicht Morgen werden-

Und die seidige Nacht uns beiden

Tausendmalimmer um den Hals geschlungen.

Wie ich mich drehen muß!

Und meine Freundin küßt taumelnd den Rosigtau Unter dem Düster des Trauerbaums. 
OUR LOVE SONG

Under the sadness of the ash tree Smile the eyes of her my friend.

And I must cry

Everywhere where roses bloom.

Both of us do not hear our name-

Sleepwalkers always in the night among the colorful young men.

My friend is juggling with the moon,

Our game of stars is followed by startled people.

Oh, our mad fantasies intoxicate

The streets and squares of the city.

All the dreams listen spellbound behind the hedges

The morning cannot dawn-

And the silken night is wound

A thousand-times-always around our necks.

How I must whirl about!

And my friend kisses reeling the rosy dew

Under the gloomy of the mourning tree. 
ABDUL ANTINOUS

Deine Schlankheit fließt wie dunkles Geschmeide.

O du meine wilde Mitternachtssonne,

Küsse mein Herz, meine rotpochende Erde.

Wie groß aufgetan deine Augen sind-

Du hast den Himmel gesehn

So nah, so tief.

Und ich habe auf deiner Schulter

Mein Land gebaut-

Wo bist du?

Zögernd wie dein Fuß ist der Weg-

Sterne werden meine Blutstropfen. . . .

$\mathrm{Du}$, ich liebe dich, ich liebe dich. 
ABDUL ANTINOUS

Your slimness flows like a dark jewelry.

$O$ you, my savage midnight sun;

Kiss my heart, my own red-throbbing earth.

How wide your eyes stand open-

You have seen the sky

So near, so deep.

And I have built my land

Upon your shoulder-

Where are you?

Like your foot, the path is hesitant--

The drops of my blood become stars. . . .

You, I love you, I love you. 
PABLO

Pablo nachts höre ich die Palmenblätter Unter deinen Füßen rascheln.

Manchmal muß ich sehr weinen

Um dich vor Glück-

Dann wächst ein Lächeln

Auf deinem lässigen Lide.

Oder es geht dir eine seltene Freude auf:

Deines Herzens schwarze Aster.

Immer wenn du an Gärten vorbei

Das Ende deines Weges erblickst, Pablo,

-Es ist mein ewiger Liebesgedanke,

Der zu dir will.

Und oft wird Schimmer vom Himmel fallen,

Denn es sucht dich am Abend mein goldener Seufzer.

Bald kommt der schmachtende Monat

Über deine holde Stadt;

Unter dem Gartenbaum hängen

Wie bunte Trauben die Vögelscharen,

Und auch ich warte verzaubert

Von Traum behangen.

Du stolzer Eingeborener, Pablo,

Von deinem Angesicht atme ich fremde Liebeslaute;

In deiner Schläfe aber will ich meinen Glücksstern pflanzen,

Mich berauben meiner leuchtenden Blüte. 
PABLO

Pablo at night $I$ hear the palm leaves

Rustle beneath your feet.

Sometimes I have to cry a lot

From happiness about you.

Then a smile grows

On your hooded eyelids.

Or a rare joy opens for you:

Your heart's black aster.

Whenever past the gardens

You see the end of your pathway, Pablo,

-It's my eternal thought of love

Desiring to join you.

And often a glow will fall from heaven,

For in the evening my golden sigh goes searching for you.

Soon the languishing month arrives

Over your dear city;

Under the garden tree there hang

Flocks of birds like gaily colored grapes.

And I too wait enchanted

Hung about by dream.

You proud native, Pablo,

I breathe from your countenance strange sounds of love;

But on your brow I want to plant my fortunate star, Rob myself of my luminous blossom. 
ABSCHIE D

Ich wollte dir immerzu

Viele Liebesworte sagen,

Nun suchst du ruhlos

Nach verlorenen Wundern.

Aber wenn meine Spieluhren spielen

Feiern wir Hochzeit.

$\mathrm{O}$, deine süßen Augen

Sind meine Lieblingsblumen.

Und dein Herz ist mein Himmelreich. . . .

$\mathrm{Laß}$ mich hineinschaun.

Du bist ganz aus glitzernder Minze

Und so weich versonnen.

Ich wollte dir immerzu

Viele Liebesworte sagen,

Warum tat ich das nicht? 
Over and over I wanted to

Say to you many words of love.

You search now restlessly After lost miracles.

But when my music boxes play We'll hold our wedding.

Oh, your sweet eyes

Are my favorite flowers.

And your heart is my kingdom of heaven. . . . Let me peer into it.

You are all of glittering mint And so softly dreamy.

Over and over I wanted to Say to you many words of love; Why didn't I do it? 
DER MÖNCH

In deinem Blick schweben

Alle Himmel zusammen.

Immer hast du die Madonna angesehn,

Darum sind deine Augen überirdisch.

Und mein Herz wird ein Weihbecken,

Besterne dich mit meinem Blut;

Ich will der Tau deiner Frühe sein, Deiner Abendsehnsucht pochendes Amen.

Du bist heilig zwischen bösem Tanz

Und schrillen Flöten.

Gottes Nachtigall bist du

In seinem Hirtentraum.

Deine Sünden wurden Musik,

Die bewegt süß meine Züge;

Deine Tränen tranken schlafende Blumen,

Die wieder Paradies werden sollen.

Ich liebe dich zauberisch wie im Spiegel des Bachs Oder fern im wolkengerahmten Blau. 
THE MONK

In your glance all the heavens Float together.

You were always watching the Madonna;

That's why your eyes are so unearthly.

And my heart becomes a holy font;

Bestar yourself here with my blood.

I want to be the dew of your youth,

The pulsing amen of your evening's longing.

You are holy, between evil dance

And shrilling flutes.

God's nightingale you are

In His shepherd's dream.

Your sins became music;

It sweetly moves my features;

Your dreams drank sleeping flowers

Which were to be paradise again.

I love you magically, as in the mirror of the stream, Or far in the cloud-framed blue. 
DEM MÖNCH

Ich taste überall nach deinem Schein.

Suchst du mich auch?

In meiner Stirne leuchtet

Der erblaßte Stern wieder,

Und sehe dich nur in der Welt,

Dein Lächeln immerfort.

Unsere himmelweißen Herzen

Erglühen im Schlaf.

O wir möchten uns küssen,

Aber es wäre wie Mord.

Ich stehe ganz bunt am Granatbaum In einem Bilderbuch.

Manchmal schaust du auf michDann singen die Junivögel. 
TO THE MONK

Everywhere I grope for your bright seeming.

Do you seek me too?

On my forehead gleams

Once more the faded star,

And I see you only in the world,

Your smile forever.

Our sky-white hearts

Begin to glow in sleep.

Oh we'd like to kiss

But it would be like murder.

I stand quite colorfully at the pomegranate tree In a picture book.

Sometimes you look at meThen the June birds sing. 
DEM MÖNCH

Meine Zehen wurden Knospen.

-Sieh, so komm ich zu dir.

Du bist am Rand über dem Tal

Die leuchtende Großkornblume;

Mit deinem Glück färbt sich

Der Himmel die Wangen blau.

Immer öffnet sich mein Wesen-

- Bin eine glitzernde Nische,

Aber du kommst nie zu deiner Anbetung, Und morgen ist ewige Nacht.

Meine Sehnsucht ist im Sturm meiner Augen

Lange schon verwittert,

Die Korallen in meinem Blut

Sind ganz erblaßt.

Zwischen Dunkelheit verlischt mein Leben

Im scheidenden Antlitz des Mondes. 
TO THE MONK

My toes became flower buds.

-See, thus I come to you.

At the rim of the valley you are

The luminous great cornflower.

Heaven dyes its cheeks

Blue with your happiness.

My being always opens-

- I'm a glittering niche,

But you never come to your worship

And tomorrow is endless night.

My longing has, in the storm of my eyes,

Long ago weathered away.

The corals in my blood

Are gone quite pale.

Between darkness my life is extinguished In the departing countenance of the moon. 
EIN LIED

Hinter meinen Augen stehen Wasser,

Die muß ich alle weinen.

Immer möcht ich auffliegen,

Mit den Zugvögeln fort;

Buntatmen mit den Winden

In der großen Luft.

$\mathrm{O}$ ich bin so traurig -.--

Das Gesicht im Mond weiß es.

Drum ist viel samtne Andacht

Und nahender Frühmorgen um mich.

Als an deinem steinernen Herzen

Meine Flügel brachen,

Fielen die Amseln wie Trauerrosen

Hoch vom blauen Gebüsch.

Alles verhaltene Gezwitscher

Will wieder jubeln,

Und ich möchte auffliegen

Mit den Zugvögeln fort. 
A SONG

Behind my eyes stand the waters;

I have to weep them all.

Always I'd like to take flight

With the birds moving on.

Bright breathe with the winds

In the vast air.

Oh I am so sad - - - -

The face in the moon well knows.

That's why much velvet devotion

And approaching morn surround me.

When on your stony heart

My wings were broken,

Blackbirds fell like funeral roses

Out of the high blue bush.

All of the long restrained twitter

Wants to rejoice again,

And I would like to take flight

With the birds moving on. 
HEIMLICH ZUR NACHT

Ich habe dich gewählt

Unter allen Sternen.

Und bin wach-eine lauschende Blume Im summenden Laub.

Unsere Lippen wollen Honig bereiten, Unsere schimmernden Nächte sind aufgeblüht.

An dem seligen Glanz deines Leibes Zündet mein Herz seine Himmel an-

Alle meine Träume hängen an deinem Golde, Ich habe dich gewählt unter allen Sternen. 
I have chosen you Among all stars.

And am awake-a listening flower In the hum of the leaves.

Our lips are eager to prepare their honey;

Our shimmering nights have blossomed forth.

On the blessed splendor of your body

My heart ignites its heavens.

All of my dreams hang from your gold;

I have chosen you among all stars. 
FRANZ WERFEL

Ein entzückender Schuljunge ist er;

Lauter Lehrer spuken in seinem Lockenkopf.

Sein Name ist so mutwillig:

Franz Werfel.

Immer schreib ich ihm Briefe,

Die er mit Klecksen beantwortet.

Aber wir lieben ihn alle

Seines zarten, zärtlichen Herzens wegen.

Sein Herz hat Echo,

Pocht verwundert.

Und fromm werden seine Lippen

Im Gedicht.

Manches trägt einen staubigen Turban.

Er ist der Enkel seiner eigenen. Verse.

Doch auf seiner Lippe

Ist eine Nachtigall gemalt.

Mein Garten singt,

Wenn er ihn verläßt.

Freude streut seine Stimme

Über den Weg. 
FRANZ WERFEL

He's a delightful schoolboy,

Full of teachers that haunt his curly head.

His name is so roguish:

Franz Werfel.

The letters I always write him

He answers with inkblots.

But we all love him

Because of his delicate, tender heart.

His heart has an echo,

Beats astonished.

And his lips become pious

In his poems.

Much of it wears a dusty turban.

He's his own verses' grandson.

But on his lips

A nightingale is painted.

My garden sings

When he leaves it.

His voice strews joy

Upon the way. 
PETER BAUM

Er war des Tannenbaums Urenkel,

Unter dem die Herren zu Elberfeld Gericht hielten.

Und freute sich an jedes glitzernd Wort

Und ließ sich feierlich plündern.

Dann leuchteten die beiden Saphire

In seinem fürstlichen Gesicht.

Immer drängte ich, wenn ich krank lag,

»Peter Baum soll kommen!!»

Kam er, war Weihnachten-

Ein Honigkuchen wurde dann mein Herz.

Wie konnten wir uns freuen!

Beide ganz egal.

Und oft bewachte er

Im Sessel schmausend meinen Schlummer.

Rote und gelbe Cyllaxbonbons aß er so gern;

Oft eine ganze Schüssel leer.

Nun schlummert unser lieber Pitter

Schon ewige Nächte lang.

„Wenn ich Euch alle glücklich erst

Im Himmel hätte-"

Sagte einmal gläubig zu den Söhnen

Seine Mutter.

Nun ist der Peter fern bewahrt

Im Himmel.

Und um des Dichters Riesenleib auf dem Soldatenkirchhof Wächst sanft die Erde pietätvoll. 
He was the fir tree's great-grandson

Under which the Lords of Elberfeld held court.

And took delight in every glittering word

And let himself be plundered festively.

Then both the sapphires glowed

In his princely face.

When I was sick, I always insisted:

"Have Peter Baum come over!!"

Whenever he came it was Christmas-

My heart turned to honey-cake then.

How jolly we were together!

Both of us just the same.

And often he guarded my slumber

Feasting in the easy chair.

He loved to eat red and yellow cyllax candies;

Sometimes emptied a whole bowl.

Now our dear Pete's been slumbering

These many endless nights.

"If only I already had you all

Happily in heaven-"

His mother once said devoutly

To her sons.

Now Peter is safely put away

In distant heaven.

And around the poet's vast body at the soldiers' cemetery The earth grows soft and reverently. 
GEORG TRAKL

Georg Trakl erlag im Krieg von eigener Hand gefällt. So einsam war es in der Welt. Ich hatt ihn lieb.

GEORG TRAKL

Seine Augen standen ganz fern.

Er war als Knabe einmal schon im Himmel.

Darum kamen seine Worte hervor Auf blauen und auf weißen Wolken.

Wir stritten über Religion, Aber immer wie zwei Spielgefährten, Und bereiteten Gott von Mund zu Mund. Im Anfang war das Wort.

Des Dichters Herz, eine feste Burg, Seine Gedichte: Singende Thesen.

Er war wohl Martin Luther.

Seine dreifaltige Seele trug er in der Hand, Als er in den heiligen Krieg zog.

-Dann wußte ich, er war gestorben-

Sein Schatten weilte unbegreiflich Auf dem Abend meines Zimmers. 
GEORG TRAKL

Georg Trakl died in the war, cut down by his own hand. So lonely was the world. I loved him.

GEORG TRAKL

His eyes stared far away.

Once as a boy he had already been in heaven.

That's why his words came forth

On clouds of blue and white.

We argued about religion,

But always like two playmates,

And prepared God from mouth to mouth.

In the beginning was the Word.

The poet's heart, a mighty fortress,

His poems: singing theses.

Probably he was Martin Luther.

His trinitarian soul he carried in his hand When he went to the holy war.

- Then I knew he had died-

Incomprehensibly his shadow tarried In the evening of my room. 
ALICE TRÜBNER

Ihr Angesicht war aus Mondstein,

Darum mußte sie immer träumen.

Durch die Seide ihrer Ebenholzhaare

Schimmerte Tausendundeinenacht.

Ihre Augen weihsagten.

Ein goldenes Bibelblatt war ihr Herz.

Sie thronte einen Himmel hoch

Über die Freunde.

O sie war eine Sternin-

Schimmer streute sie von sich.

Eine Herzogin war sie

Und krönte den armseligsten Gast.

Manchmal aber kam sie vom West:

Ein Wetter in Blitzfarben;

Die sind gefangen über Burgzacken

Im harten Rahmen.

Ihre Bilder viele,

Pietätvolle, bunte Briefe;

Manche aufbewahrt unter Glas

An den Wänden.

Aber auch Gläser und Gräser

Malte Alice Trübner.

Irgendwo zwischen sitzt ein Schelm,

Ein altmodisch dicker Puppenporzellankopf.

Oder sie malte huldvoll die Köchin

Als Frau Lucullus gelassen im Lehnstuhl.

Verwandelte strotzende Früchte in Rosen

Auf weißem Damast.

$O$, sie war eine Zauberin. 
Her face was made of moonstone; That's why she was forever dreaming.

Through the silk of her ebony hair A Thousand and One Nights came shimmering.

Her eyes spoke consecration.

Her heart was a golden Bible page.

Sky-high uprose her throne Above her friends.

Oh she was a staress-

Strewed shimmering light around her.

A countess, And crowned the most pitiful guest.

But sometimes she came from the West:

A lightning-colored storm;

It's caught above castle crags

In the hard frame.

Her many pictures,

Reverent, colorful letters;

Many preserved under glass

On the walls.

But Alice Trübner painted

Glasses and grasses also.

Somewhere among them sits a rogue,

A fat, old-fashioned head of a porcelain doll.

Or she graciously painted the cook

As Lady Lucullus relaxed in an easy chair.

Bursting fruit she transformed into roses

On white damask.

Oh, she was a sorceress. 
GEORG GROSZ

Manchmal spielen bunte Tränen In seinen äschernen Augen.

Aber immer begegnen ihm Totenwagen,

Die verscheuchen seine Libellen.

Er ist abergläubig-

-Ward unter einem großen Stern geboren-

Seine Schrift regnet,

Seine Zeichnung: Trüber Buchstabe.

Wie lange im Fluß gelegen,

Blähen seine Menschen sich auf.

Mysteriöse Verlorene mit Quappenmäulern

Und verfaulten Seelen.

Fünf träumende Totenfahrer

Sind seine silbernen Finger.

Aber nirgendwo ein Licht im verirrten Märchen

Und doch ist er ein Kind,

Der Held aus dem Lederstrumpf

Mit dem Indianerstamm auf Duzfuß.

Sonst haßt er alle Menschen,

Sie bringen ihm Unglück.

Aber Georg Grosz liebt sein Mißgeschick

Wie einen anhänglichen Feind.

Und seine Traurigkeit ist dionysisch,

Schwarzer Champagner seine Klage.

Er ist ein Meer mit verhängtem Mond,

Sein Gott ist nur scheintot. 
Colorful tears will sometimes play

In his ashen eyes.

But he's always meeting funeral processions;

They chase away his dragonflies.

He's superstitious-

-Was born under a mighty star-

His handwriting rains;

His sketches: gloomy alphabet.

As if they'd lain a long time in the river,

His people puff and swell.

The mysterious lost, with tadpole maws

And rotten souls.

Five dreaming drivers of the dead

Are his silver fingers.

But nowhere a light in the fairy tale gone astray

And yet he is a child,

A hero like Leather Stocking

On familiar terms with the Indians.

Otherwise, he hates everybody;

They bring him bad luck.

But Georg Grosz loves his misfortune

Like an affectionate enemy.

And his sadness is Dionysian,

His plaint black champagne.

He is an ocean with clouded moon;

His God only seems to be dead. 
HEINRICH MARIA DAVRINGHAUSEN

-Wie er daherkommt-

Trojanischer junger Priester

Auf grabaltem Holzgefäß.

Zwei Nachtschatten schlaftrinken

In seinem Mahagonikopf,

Seine Lippen küßte ein Gottmädchen hold.

-Wie er gefalten aufstrebt-

Immer tragen seine Schultern

Ehrfürchtigen Samt.

Seine Füße schreiten

Nur über gepflegte Wege,

Stolperten nie über Gestrüpp.

-Wie er gottverhalten ist-

Aus jedem Bild, das er malt,

Blickt allfarbig der Schöpfer. 
HEINRICH MARIA DAVRINGHAUSEN

- How he comes walking-

Young Trojan priest

On a grave-old wooden vase.

Two night shadows sleep-drink

In his mahogany head;

A god-maiden kissed his lips sweet.

- How he strives upward, folded-

His shoulders wearing

Respectful velvet.

His feet go striding

Only on well-tended ways,

Never stumbled in underbrush.

- How god-reserved he is-

Out of each picture he paints

Peers the creator in every color. 
MILLY STEGER

Milly Steger ist eine Bändigerin, Haut Löwen und Panther in Stein.

Vor dem Spielhaus in Elberfeld

Stehen ihre Großgestalten;

Böse Tolpatsche, ernste Hännesken, Clowne, die mit blutenden Seelen wehen.

Aber auch Brunnen, verschwiegene Weibsmopse Zwingt Milly rätselhaft nieder.

Manchmal schnitzt die Gulliverin

Aus Zündhölzchen Adam und hinterrücks sein Weib.

Dann lacht sie wie ein Apfel;

Im stahlblauen Auge sitzt der Schalk.

Milly Steger ist eine Büffelin an Wurfkraft;

Freut sie sich auch an dem blühenden Kern der Büsche. 
MILLY STEGER

Milly Steger is an animal tamer;

Chisels panthers and lions in stone.

Her monumental figures stand

In front of the Elberfeld Theater.

Wicked louts, dead-serious numbskulls,

Clowns that wave their bleeding souls.

But also fountains, discreet, plump females, Milly mysteriously subjugates them.

Sometimes this lady Gulliver carves

Adam from matchsticks and-behind his back-his wife.

Then she laughs like an apple;

A rascally look in her steel-blue eye.

Milly Steger is a workhorse in full career;

The blooming root of the bushes makes her happy too. 
LEO KESTENBERG

Seine Hände zaubern Musik durch stille Zimmer. Zwischen uns sitzt dann der ehrwürdige Mond Goldbehäbig im Lehnstuhl

Und versöhnt uns mit der Welt.

Wenn Leo Kestenberg Flügel spielt, Ist er ein heiliger Mann;

Erweckt Liszt aus steinernem Schlaf, Bach feiert Himmelfahrt.

Mit Schumann wird Leo ein Kind Und Schwärmer am Süßfeuer Chopins.

Der dunkle Flügel verwandelt sich aber zur Orgel Wenn Kestenberg eigene Rosen spielt.

Sein schweres Ebenholzherz frommütig aufhebt Und weicher Musikregen uns durchrieselt. 
LEO KESTENBERG

His hands can conjure music through still rooms.

Between us sits the reverend moon

Portly as gold in the armchair,

And reconciles us with the world

When Leo Kestenberg plays the grand piano

He is a holy man.

Wakens Liszt from stony sleep;

Bach celebrates ascension.

With Schumann Leo becomes a child

And a dreamer at the sweet fire of Chopin.

But the dark piano changes to an organ

When Kestenberg is playing his own roses.

His heavy ebony heart lifts piously

And through us trickles the soft music's rain. 
Seiner Heimat Erde ruht An keiner Bergwand aus;

Ein weiter, weiter SchemelFriesland.

Ungehemmt wettern die Wetter Und die stürmenden Gemüter dort.

Im lüttchen Städtchen Weener Hockt Ludwigs zottigsteinern Elternnest.

Da einmal flog er mit den Herbstvögeln Fort über die Ems.

Von hoher Vogelreinheit inbrünstig

Ohne Makel klopft sein Herz.

Und geharnischt ist seine Nase, Seidene Spenderinnen die feinen Lippen,

Wenn sie die Verse Maria

Rainer Rilkes gastlich reichen.

Werden Rittersporn

In Liliencrons Balladengesängen;

Flattern wie Möven auf,

Lauter »Emmas", wenn er entzückend

Uns mit Morgensterns

—frei nach Hardt-»kosmischer Meschuggas» beschenkt.

Oh, Ludwig Hardt liebt seine Dichter,

Die er spricht.

Und vermählt sich mit den Gedichten,

Die er schlicht zu sagen versteht.

Nie deklamiert er!

Das ist es eben. 
LUDWIG HARDT

The earth of his homeland doesn't rest

On any mountain wall.

A wide, wide footstool-

Frisia.

The storms roar uninhibited there And the stormy spirits too.

In the itty-bitty city of Weener

Squats Ludwig's shaggy stone parental nest.

From there he flew with the Autumn birds one day

Over the Ems and away.

Fervent with great bird-purity

His heart is immaculate.

And his nose is up in arms,

The fine lips are silken donoresses,

When they hospitably serve

Their verses of Maria Rainer Rilke.

They become larkspur, lance-like, In the ballads of Liliencron;

Flutter like seagulls,

"Emmas" all, when with great charm

He honors us with Morgenstern's

"Cosmic meschuggas" (to paraphrase Hardt).

O Ludwig Hardt loves the poets

That he recites.

And marries the poems

That he can speak with such simplicity.

He never declaims!

That's just the point. 
WILHELM SCHMIDTBONN

Er ist der Dichter, dem der Schlüssel Zur Steinzeit vermacht wurde.

Adam den Urkäfer trägt er, Ein Skarabäus im Ring.

Wilhelm Schmidtbonn erzählt vom Paradies;

Reißst den verlogenen Nebel vom Baum:

Stolz blüht die Dolde der Erkenntnis.

Sein markisches Gesicht strömt immer

Zwei dämmerblaue Kräfte aus.

Er ist aus Laub und Rinde,

Morgenfrühe und Kentauerblut.

Wie oft schon ließ er sich zur Ader

Seine Werke zu tränken.

Sein neustes Versspiel stiert aus Einauge. 
WILHELM SCHMIDTBONN

He is the poet to whom was left The key to the Stone Age.

He carries the old dawn-beetle Adam, A scarab in his ring.

Wilhelm Schmidtbonn tells about Paradise; Rips the hypocritical mist from the tree:

The flowers of knowledge blossom proudly.

His Prussian face beams out

Two dusk-blue forces.

He's made of leaf and bark, Of early morn and centaur blood.

How often he has tapped his veins To drench his work.

His newest verse-play stares out of one eye. 
Der blaue Reiter ist gefallen, ein Großbiblischer, an dem der Duft Edens hing. Über die Landschaft warf er einen blauen Schatten. Er war der, welcher die Tiere noch reden hörte; und er verklärte ihre unverstandenen Seelen. Immer erinnerte mich der blaue Reiter aus dem Kriege daran: es genügt nicht alleine, zu den Menschen gütig zu sein, und was du namentlich an den Pferden, da sie unbeschreiblich auf dem Schlachtfeld leiden müssen, Gutes tust, tust du mir.

Er ist gefallen. Seinen Riesenkörper tragen große Engel zu Gott, der hält seine blaue Seele, eine leuchtende Fahne, in seiner Hand. Ich denke an eine Geschichte im Talmud, die mir ein Priester erzählte: wie Gott mit den Menschen vor dem zerstörten Tempel stand und weinte. Denn wo der blaue Reiter ging, schenkte er Himmel. So viele Vögel fliegen durch die Nacht, sie können noch Wind und Atem spielen, aber wir wissen nichts mehr hier unten davon, wir können uns nur noch zerhacken oder gleichgültig aneinander vorbeigehen. In dieser Nüchternheit erhebt sich drohend eine unermeßliche Blutmühle, und wir Völker alle werden bald zermahlen sein. Schreiten immerfort über wartende Erde. Der blaue Reiter ist angelangt; er war noch zu jung zu sterben.

$\mathrm{Nie}$ sah ich irgendeinen Maler gotternster und sanfter malen wie ihn. "Zitronenochsen" und "Feuerbüffel" nannte er seine Tiere, und auf seiner Schläfe ging ein Stern auf. Aber auch die Tiere der Wildnis begannen pflanzlich zu werden in seiner tropischen Hand. Tigerinnen verzauberte er zu Anemonen, Leoparden legte er das Geschmeide der Levkoje um; er sprach vom reinen Totschlag, wenn auf seinem Bild sich der Panther die Gazell vom Fels holte. Er fühlte wie der junge Erzvater in der Bibelzeit, ein herrlicher Jakob er, der Fürst von Kana. Um seine Schultern schlug er wild das Dickicht; sein schönes Angesicht spiegelte er im Quell und sein Wunderherz trug er oftmals in Fell gehüllt, wie ein schlafendes Knäblein heim, über die Wiesen, wenn es müde war.

Das war alles vor dem Krieg.

Franz Marc, der blaue Reiter vom Ried, Stieg auf sein Kriegspferd.

Ritt über Benediktbeuern herab nach Unterbayern,

Neben ihm sein besonnener, treuer Nubier

Hält ihm die Waffe. 
The Blue Rider has fallen in battle, a great Biblical figure, about whom the fragrance of Eden hung. Over the landscape his blue shadow fell. He was the one who could still hear the animals speak; and he transfigured their uncomprehended souls. The Blue Rider from the war always reminded me of that: it does not suffice alone to be kind to human beings, and the good that you do to the horses, since they must suffer unspeakably on the battlefield, you also do to me.

He is dead. Great angels bore his giant body to God, who holds his blue soul in His hand, like a glowing flag. I think of a story in the Talmud that a priest once told to me: how God stood in front of the ruined temple with men and wept. For wherever the Blue Rider went he made a gift of heaven. So many birds fly through the night; they can still play wind and breath, but we know nothing more about that down here; we can only chop each other to bits or indifferently pass each other by. In this soberness an immense blood-mill is raised up threateningly, and we people all will soon be crushed. Stride perpetually across the waiting earth. The Blue Rider has arrived; he was still too young to die.

I never saw any painter paint softer and with greater godlike seriousness than he. "Lemon oxen" and "burning buffaloes" was what he called his animals, and a star ascended on his brow. But the animals of the wilderness, they too, began to become like plants in his tropical hand. He enchanted tigresses into anemones; around panthers he hung the jewels of the gillyflower; he spoke of pure slaughter when, in his pictures, a panther brought down a gazelle from the cliffs. He felt himself like a young arch-father in Biblical times, a splendid Jacob he, the Prince of Cana. Wildly he folded the thicket around his shoulders; his beautiful face he mirrored in the spring, and often he bore his miraculous heart wrapped up in fur, home like a sleeping boy-child, over the meadows when it was tired.

That was all before the war.

Franz Marc, the Blue Rider of Ried,

Mounted his war horse.

Rode over Benediktbeuern down into Lower Bavaria;

Beside him his prudent, loyal Nubian

Carries his weapon. 
Aber um seinen Hals trägt er mein silbergeprägtes Bild Und den todverhütenden Stein seines teuren Weibes.

Durch die Straßen von München hebt er sein biblisches Haupt Im hellen Rahmen des Himmels.

Trost im stillenden Mandelauge,

Donner sein Herz.

Hinter ihm und zur Seite viele, viele Soldaten.

MEIN KIND

Mein Kind schreit auf um die Mitternacht

Und ist so heiß aus dem Traum erwacht.

Gäb ihm so gern meines Blutes Mai, Spräng nur mein bebendes Herz entzwei.

Der Tod schleicht im Hyänenfell

Am Himmelsstreif im Mondeshell.

Aber die Erde im Blütenkeusch

Singt Lenz im kreisenden Weltgeräusch.

Und wundersüß küßt der Maienwind

Als duftender Gottesbote mein Kind. 
But around his neck he wears my picture in silver And the death-averting stone of his precious wife.

Through the streets of Munich he lifts his Biblical head In the brilliant frame of the sky.

Solace in his silencing almond eye,

Thunder his heart.

Behind him and at his side many, many soldiers.

MY CHILD

I hear my child at midnight scream, Awakened from the sweat of dream.

The May of my blood he could gladly take If only my throbbing heart would break.

Death slinks in a hyena's skin Through the bright moonlight on the heaven's rim.

But the earth, in budding chasteness furled, Sings Spring in the sound of the circling world.

And wonderfully sweet the May wind nods To kiss my child like a breath from the gods. 
DIE PAVIANMUTTER

SINGT IHR PAVIÄNCHEN IN DEN SCHLAF

(Wiegenliedchen)

Schlafe, schlafe,

Mein Rosenpöpöchen,

Mein Zuckerläuschen,

Mein Goldflöhchen,

Morgen wird die Kaiserin aus Asien kommen

Mit Zucker, Schokoladen und Bombommen,

Schnell, schnell,

Haase Haase machen,

Sonst kriegt Blaumäulchen nichts von den Sachen.

ANTINOUS

Der kleine Süßkönig

Muß mit goldenen Bällen spielen.

Im bunten Brunnen

Blaugeträufel, honiggold,

Seine Spielehände kühlen.

Antinous,

Wildfang, Güldklang,

Kuchenkorn mahlen alle Mühlen.

Antinous,

Du kleiner Spielkönig,

In den Himmel fährt es schön auf Schaukelstühlen.

$\mathrm{O}$, wie lustige Falter seine Augen sind

Und die Schelme all in seiner Wange,

Und sein Herzchen beißt, will mans befühlen. 
THE BABOON MOTHER

SINGS HER BABOONLET TO SLEEP

(Lullaby)

Sleep, go to sleep,

My little rose bottom,

My little sugar louse,

My dear little flea,

The Empress of Asia will come tomorrow

With sugar, candy, and chocolorrow,

Quick, quick,

Make Bunny Bunny

Or little blue-mouth gets none of the honey.

ANTINOUS

The little sweet-king

Must play with golden balls.

In the bright fountain

Blue-trickle, honey-gold,

His play-hands are cooling.

Antinous,

Mad-cap, gilt-sound,

All the mills grind cake-grain.

Antinous,

You little play-king,

It's a fine ride to heaven in rocking chairs.

Oh, what funny butterflies his eyes are

And all the rogues in his cheek,

And his heart bites, if you try to feel it. 
Mein Herz ist eine traurige Zeit,

Die tonlos tickt.

Meine Mutter hatte goldene Flügel,

Die keine Welt fanden.

Horcht, mich sucht meine Mutter,

Lichte sind ihre Finger und ihre Füße wandernde Träume.

Und süße Wetter mit blauen Wehen

Wärmen meine Schlummer

Immer in den Nächten,

Deren Tage meiner Mutter Krone tragen.

Und ich trinke aus dem Monde stillen Wein,

Wenn die Nacht einsam kommt.

Meine Lieder trugen des Sommers Bläue

Und kehrten düster heim.

-Ihr verhöhntet meine Lippe

Und redet mit ihr.-

Doch ich griff nach euren Händen,

Denn meine Liebe ist ein Kind und wollte spielen.

Und ich artete mich nach euch,

Weil ich mich nach dem Menschen sehnte.

Arm bin ich geworden

An eurer bettelnden Wohltat.

Und das Meer wird es wehklagen

Gott.

Ich bin der Hieroglyph,

Der unter der Schöpfung steht

Und mein Auge

Ist der Gipfel der Zeit;

Sein Leuchten küßt Gottes Saum. 
MY QUIET SONG

(Second Version)

My heart is a sad time

Tonelessly ticking.

My mother had golden wings

That found no world.

Listen! My mother's looking for me;

Her fingers are candles, her feet are wandering dreams.

And sweet weathers with blue winds

Warm my slumber

In the nights always

Whose days are wearing my mother's crown.

And from the moon I drink a quiet wine

When the night comes lonely.

My songs carried the summer's blue

And gloomily turned home.

_You scorned my lip

And speak with it.-

But I reached for your hands,

For my love is a child and wanted to play.

And I assumed your ways

Because I longed for human kind.

I have become poor

From your begging benefaction.

And the ocean will lament it

Unto God.

I am the hieroglyph

Inscribed beneath creation.

And my eye

Is the pinnacle of time;

Its lusters kiss God's hem. 
GEBET

Ich suche allerlanden eine Stadt,

Die einen Engel vor der Pforte hat.

Ich trage seinen großen Flügel

Gebrochen schwer am Schulterblatt

Und in der Stirne seinen Stern als Siegel.

Und wandle immer in die Nacht . .

Ich habe Liebe in die Welt gebracht-

Daß blau zu blühen jedes Herz vermag, Und hab ein Leben müde mich gewacht,

In Gott gehüllt den dunklen Atemschlag.

O Gott, schließ um mich deinen Mantel fest;

Ich weiß, ich bin im Kugelglas der Rest,

Und wenn der letzte Mensch die Welt vergießt,

Du mich nicht wieder aus der Allmacht läßt

Und sich ein neuer Erdball um mich schließt. 
PRAYER

I'm searching for a city in these lands

Before whose gate a mighty angel stands;

For, broken at the shoulder blade,

I bear his wings' gigantic spans,

And on my brow his star as seal is laid.

And always wander in the night ...

I brought love to the world, and light-

So every heart can blossom forth in blue;

And with my darkened breath cloaked in God's might,

I have kept weary watch my whole life through.

O God, wrap up your robe around me fast:

I know I'm just the drop left in the glass.

And as the last man stands pouring out the world,

Out of your power you'll never let me pass,

And a new globe around me will be furled. 
VERSÖHNUNG

Es wird ein großer Stern in meinen Schoß fallen ...

Wir wollen wachen die Nacht,

In den Sprachen beten,

Die wie Harfen eingeschnitten sind.

Wir wollen uns versöhnen die Nacht-

So viel Gott strömt über.

Kinder sind unsere Herzen,

Die möchten ruhen müdesüß.

Und unsere Lippen wollen sich küssen, Was zagst du?

Grenzt nicht mein Herz an deinsImmer färbt dein Blut meine Wangen rot.

Wir wollen uns versöhnen die Nacht, Wenn wir uns herzen, sterben wir nicht.

Es wird ein großer Stern in meinen Schoß fallen. 
RECONCILIATION

There will be a giant star fall in my womb . . .

Let us wake through the night,

Pray in the languages

That are incised like harps.

Let us be reconciled in the night-

So much God flows over.

Our hearts are child and child, They'd like to rest so weary-sweet.

And our lips want to kiss one another, Why do you wait?

Doesn't my heart border yours-

Your blood always colors my cheeks red.

Let us be reconciled in the night,

Whenever we embrace we do not die.

There will be a giant star fall in my womb. 
MEIN VOLK

Der Fels wird morsch,

Dem ich entspringe

Und meine Gotteslieder singe . . .

Jäh stürz ich vom Weg

Und riesele ganz in mir

Fernab, allein über Klagegestein

Dem Meer zu.

Hab mich so abgeströmt

Von meines Blutes

Mostvergorenheit.

Und immer, immer noch der Widerhall

In mir,

Wenn schauerlich gen Ost

Das morsche Felsgebein,

Mein Volk,

$\mathrm{Zu}$ Gott schreit. 
MY PEOPLE

The rock begins to crack

From which I spring

And my divine songs sing . .

Steep from the path I plunge

And trickle, all in me,

Far off, alone over grieving stone,

Toward the sea.

So much I've streamed away

Of my blood's

Early fermentation.

And always and again the echoing

In me,

When shuddering towards the East

The crumbling skeleton of stone,

My people

Cries to God. 
ABEL

Kains Augen sind nicht gottwohlgefällig, Abels Angesicht ist ein goldener Garten, Abels Augen sind Nachtigallen.

Immer singt Abel so hell $\mathrm{Zu}$ den Saiten seiner Seele, Aber durch Kains Leib führen die Gräben der Stadt.

Und er wird seinen Bruder erschlagenAbel, Abel, dein Blut färbt den Himmel tief.

Wo ist Kain, da ich ihn stürmen will: Hast du die Süßvögel erschlagen In deines Bruders Angesicht?!! 
A BE L

Cain's eyes are not well pleasing unto God;

But a golden garden is Abel's countenance;

Abel's eyes are nightingales.

So brightly does Abel always sing

To the strings of his soul

But the city ditches pass through the body of Cain.

And he'll slay his brother-

Abel, Abel, your blood will deeply dye the sky.

Where is Cain, for I would storm him:

Did you slay the sweet-bird

In the face of your brother?!! 


\author{
Abraham baute in der Landschaft Eden \\ Sich eine Stadt aus Erde und aus Blatt \\ Und übte sich mit Gott zu reden. \\ Die Engel ruhten gern vor seiner frommen Hütte \\ Und Abraham erkannte jeden; \\ Himmlische Zeichen ließen ihre Flügelschritte. \\ Bis sie dann einmal bang in ihren Träumen \\ Meckern hörten die gequälten Böcke, \\ Mit denen Isaak Opfern spielte hinter Süßholzbäumen. \\ Und Gott ermahnte: Abraham!! \\ Er brach vom Kamm des Meeres Muscheln ab und Schwamm \\ Hoch auf den Blöcken den Altar zu schmücken. \\ Und trug den einzigen Sohn gebunden auf den Rücken \\ $\mathrm{Zu}$ werden seinem großen Herrn gerecht- \\ Der aber liebte seinen Knecht.
}




\author{
Abraham built himself on Eden's sod \\ A city raised of earth and leaf \\ And practiced converse with his God. \\ The angels pleased to rest before his holy home \\ And Abraham knew every one; \\ Their wingèd steps left symbols in the loam. \\ Until they then once heard in fearful dreams \\ The bleating of tormented rams \\ Where Isaac was playing sacrifice behind the licorice trees. \\ And God admonished: Abraham! \\ From the ridge of the sea he broke off sponge and clam \\ To trim the altar towering up in stone. \\ And bound on his back he bore his only son \\ Since that his Lord's command did him compel- \\ The Lord, however, loved his servant well.
}


Mit Muscheln spielten Abrahams kleine Söhne Und ließen schwimmen die Perlmutterkähne;

Dann lehnte Isaak bang sich an den Ismael

Und traurig sangen die zwei schwarzen Schwäne

Um ihre bunte Welt ganz dunkle Töne,

Und die verstoßne Hagar raubte ihren Sohn sich schnell.

Vergoß in seine kleine ihre große Träne, Und ihre Herzen rauschten wie der heilige Quell, Und übereilten noch die Straußenhähne.

Die Sonne aber brannte auf die Wüste grell

Und Hagar und ihr Knäblein sanken in das gelbe Fell Und bissen in den heißen Sand die weißen Negerzähne.

JAKOB UND ESAU

Rebekkas Magd ist eine himmlische Fremde, Aus Rosenblättern trägt die Engelin ein Hemde Und einen Stern im Angesicht.

Und immer blickt sie auf zum Licht, Und ihre sanften Hände lesen

Aus goldenen Linsen ein Gericht.

Jakob und Esau blühn an ihrem Wesen Und streiten um die Süßigkeiten nicht, Die sie in ihrem Schoß zum Mahle bricht.

Der Bruder läßt dem jüngeren die Jagd Und all sein Erbe für den Dienst der Magd;

Um seine Schultern schlägt er wild das Dickicht. 
HAGAR AND ISHMAEL

The little sons of Abraham took shells

And floated boats made out of mother-pearl;

Then Isaac leaned in fear on Ishmael.

And mournfully sang the two black swans

Quite gloomy notes around their brilliant world, And the banished Hagar quickly stole her son.

Poured into his small tear her larger one, And their hearts murmured like a sacred well And could the swiftest ostriches outrun.

But the sun on the desert dazzled like a brand, And into its yellow fur the boy and Hagar fell And their white negroes' teeth bit burning sand.

JACOB AND ESAU

Rebecca's maiden is a heavenly stranger.

A garment of rose petals garbs the angel And in her face a star.

And she looks upward at the light afar, And her soft hands and gentle Are shelling a pottage of golden lentil.

Jacob and Esau blossom from her being, Nor seek those sweetnesses with quarrelsome zeal, That in her lap she breaks to make the meal.

One brother sells the younger undismayed, His hunt and heritage to serve the maid; Bursts shouldering through the thicket and away. 
JAKO B

Jakob war der Büffel seiner Herde.

Wenn er stampfte mit den Hufen,

Sprühte unter ihm die Erde.

Brüllend ließ er die gescheckten Brüder.

Rannte in den Urwald an die Flüsse,

Stillte dort das Blut der Affenbisse.

Durch die müden Schmerzen in den Knöcheln

Sank er vor dem Himmel fiebernd nieder, Und sein Ochsgesicht erschuf das Lächeln. 
JACOB

Jacob was the buffalo of his herd. When he thundered with his hooves

Earth beneath him rocked and stirred.

Bellowed, left his many-colored brothers, Ran through jungle to the cool lagoons,

Staunched the blood there of his ape-bite wounds.

Fever forced him to sink down a while Under heaven, to rest his painful bones;

And his ox-face bore the world's first smile. 
PHARAO UND JOSEPH

Pharao verstößt seine blühenden Weiber,

Sie duften nach den Gärten Amons.

Sein Königskopf ruht auf meiner Schulter, Die strömt Korngeruch aus.

Pharao ist von Gold.

Seine Augen gehen und kommen

Wie schillernde Nilwellen.

Sein Herz aber liegt in meinem Blut;

Zehn Wölfe gingen an meine Tränke.

Immer denkt Pharao

An meine Brüder,

Die mich in die Grube warfen.

Säulen werden im Schlaf seine Arme Und drohen!

Aber sein träumerisch Herz

Rauscht auf meinem Grund.

Darum dichten meine Lippen

Große Süßigkeiten,

Im Weizen unseres Morgens. 
PHARAOH AND JOSEPH

Pharaoh dismisses his blossoming wives;

They are fragrant as Amon's gardens.

His royal head rests upon my shoulder, Which sends forth the scent of grain.

Pharaoh is golden.

His eyes come and go

Like shimmering waves of the Nile.

His heart, though, lies in my blood;

Ten wolves went to my watering place.

Pharaoh thinks always

Upon my brothers

Who cast me into the pit.

In sleep his arms become pillars

And threaten!

But his dreamer's heart

Roars on my riverbed.

Wherefore my lips are thick with words

Of very sweetness

In the wheat of our morn. 
MOSES UND JOSUA
Als Moses im Alter Gottes war, Nahm er den wilden Juden Josua
Und salbte ihn zum König seiner Schar.
Da ging ein Sehnen weich durch Israel-
Denn Josuas Herz erquickte wie ein Quell.
Des Bibelvolkes Judenleib war sein Altar.
Die Mägde mochten den gekrönten Bruder gern- Wie heiliger Dornstrauch brannte süß sein Haar; Sein Lächeln grüßte den ersehnten Heimatstern, Den Mosis altes Sterbeauge aufgehn sah, Als seine müde Löwenseele schrie zum Herrn. 
MOSES AND JOSHUA

When Moses was as old as God He took the wild Jew Joshua

And anointed him king of his multitudes.

Then a soft longing went through Israel, For Joshua's heart refreshed them like a well. His altar was the body of the Bible's Jews.

With maidens the brother king was popularLike holy thornbush did his hair burn sweet;

His smile did greet the homeland's beckoning star,

Which Moses' dying eye still lived to see When his tired lion's soul cried out to God. 
DAVID UND JONATHAN

In der Bibel stehn wir geschrieben

Buntumschlungen.

Aber unsere Knabenspiele

Leben weiter im Stern.

Ich bin David,

Du mein Spielgefährte.

$\mathrm{O}$, wir färbten

Unsere weißen Widderherzen rot!

Wie die Knospen an den Liebespsalmen

Unter Feiertagshimmel.

Deine Abschiedsaugen aber-

Immer nimmst du still im Kusse Abschied.

Und was soll dein Herz

Noch ohne meines-

Deine Süßnacht

Ohne meine Lieder. 
DAVID AND JONATHAN

In the Bible we are written

In bright embrace.

But our boyish games

Survive in the star.

I am David.

You my playmate.

Oh, we dyed

Our white ram-hearts red!

Like the buds on the love-psalms

Beneath holiday skies.

But your leave-taking eyes-

You always depart with a wordless kiss.

And what should your heart do

Without mine too-

Your sweet night

Without my song. 
O Jonathan, ich blasse hin in deinem Schoß, Mein Herz fällt feierlich in dunklen Falten; In meiner Schläfe pflege du den Mond, Des Sternes Gold sollst du erhalten.

Du bist mein Himmel mein, du Liebgenoß.

Ich hab so säumerisch die kühle Welt Fern immer nur im Bach geschaut . . . Doch nun, da sie aus meinem Auge fällt, Von deiner Liebe aufgetaut . . . O Jonathan, nimm du die königliche Träne, Sie schimmert weich und reich wie eine Braut.

O Jonathan, du Blut der süßen Feige, Duftendes Gehang an meinem Zweige, Du Ring in meiner Lippe Haut.

ESTHER

Esther ist schlank wie die Feldpalme, Nach ihren Lippen duften die Weizenhalme Und die Feiertage, die in Juda fallen.

Nachts ruht ihr Herz auf einem Psalme, Die Götzen lauschen in den Hallen.

Der König lächelt ihrem Nahen entgegenDenn überall blickt Gott auf Esther.

Die jungen Juden dichten Lieder an die Schwester, Die sie in Säulen ihres Vorraums prägen. 
O Jonathan, I pale in your embrace;

My heart is draped in dark and solemn folds. In the temple of my brow-care for the moon! And from the stars receive their gold! You are my heaven, mine, you mate of grace.

I've only viewed the cool world in the streams, Indolent, as if from far above . . . But since in my eye it now no longer gleams, Being thawed out by your love . . . O Jonathan, you, take the royal tear! It shines rich as a bride, soft as a dove.

O Jonathan, you blood of the sweet fig, You aromatic pendant on my twig, You ring, through my lip interwove.

ESTHER

Esther is slender as a palm.

The blades of wheat take from her lips their balm, And the feast days that in Judah fall.

At night her heart reposes on a psalm; The idols hearken in the hall.

The king looks, smiling, when she comesFor everywhere God watches Esther.

The young Jews compose love songs to their sister, Which they incise in the pillars before her room. 
ZEB A OTH

Gott, ich liebe dich in deinem Rosenkleide,

Wenn du aus den Gärten trittst, Zebaoth.

O, du Gottjüngling,

Du Dichter,

Ich trinke einsam von deinen Düften.

Meine erste Blüte Blut sehnte sich nach dir,

So komme doch,

$\mathrm{Du}$ süßer Gott,

Du Gespiele Gott,

Deines Tores Gold schmilzt an meiner Sehnsucht.

\section{ABSCHIED}

Der Regen säuberte die steile Häuserwand, Ich schreibe auf den weißen, steinernen Bogen Und fühle sanft erstarken meine müde Hand Von Liebesversen, die mich immer süß betrogen.

Ich wache in der Nacht stürmisch auf hohen Meereswogen! Vielleicht entglitt ich meines Engels liebevoller Hand, Ich hab' die Welt, die Welt hat mich betrogen;

Ich grub den Leichnam zu den Muscheln in den Sand.

Wir blicken all' zu einem Himmel auf, mißgönnen uns das Land?Warum hat Gott im Osten wetterleuchtend sich verzogen, Vom Ebenbilde Seines Menschen übermannt?

Ich wache in der Nacht stürmisch auf hohen Meereswogen! Und was mich je mit Seiner Schöpfung Ruhetag verband, Ist wie ein spätes Adlerheer unstät in diese Dunkelheit geflogen. 
God but I love you in your robe of rose

When you come from the garden, Sabaoth.

$O$ godlike youth,

You poet;

Lonely, I drink of your fragrances.

My first bud of blood was a yearning for you;

So come then,

You sweet god,

You playmate god,

The gold of your gate will melt from my longing.

DEPART URE

The rain cleaned off the steep facade of houses;

I write upon the white and stony sheet

And feel how my tired hand so softly rouses

From love poems that always, sweetly, were a cheat.

I wake in the stormy night, on high waves of the sea!

Perhaps I have slipped from my angel's loving hand;

I cheated the world, and the world has cheated me;

I buried the corpse with the seashells in the sand.

We all look up to a single heaven, begrudge each other land? Why has God drawn away with lightning toward the East, By the image of His human being outmanned?

I wake in the stormy night, on high waves of the sea! What bound me to the Day of Rest when His creation ceased Has flown, like a late eagle-army, into this dark unsteadily. 
DAS WUNDERLIED

Schwärmend trat ich aus glitzerndem Herzen Wogender Liebesfäden,

Ganz schüchtern, hervor; Nacht im Auge, Geöffnete Lippen . . .

Aber wo auch ein See lockte, Goldene Tränke,

Starb an der Labe mein pochendes Wild In der Brust.

Was soll mir der Wein deines Tisches,

Reichst du mir des Herzens Mannah nicht.

Süß mir, wenn ich im Rauschen der Liebe Für dich gestorben wär-

Nun ist mein Leben verschneit, Erstarrt meine Seele,

Die lächelte sonntäglich dir Friede ins Herz.

Ich suche das Glück nicht mehr.

Wo ich auch unter hochzeitlichem Morgen saß,

Erfror der träumende Lotos Auf meinem Blut. 
THE SONG OF WONDER

In rapture and from the glittering heart

Of billowing love-strings

Shyly I stepped forth; night in my eye,

Lips open ...

But wherever a lake lured,

Golden waters,

There died of refreshment the throbbing deer In my wild breast.

What use is the wine of your table to me If you don't serve the manna of your heart.

Sweet for me, if in the rush of love,

I had died for you.

Snow falls on my life now,

Numb my soul;

It sent a Sunday smile of peace

Into your heart.

Happiness I no longer seek.

Wherever under the wedding morn I sat,

The dreaming lotus froze

Upon my blood. 
GOTT HÖR . . .

Um meine Augen zieht die Nacht sich

Wie ein Ring zusammen.

Mein Puls verwandelte das Blut in Flammen

Und doch war alles grau und kalt um mich.

O Gott und bei lebendigem Tage,

Träum ich vom Tod.

Im Wasser trink ich ihn und würge ihn im Brot.

Für meine Traurigkeit gibt es kein Maß auf deiner Waage.

Gott hör . . . In deiner blauen Lieblingsfarbe

Sang ich das Lied von deines Himmels Dach-

Und weckte doch in deinem ewigen Hauche nicht den Tag.

Mein Herz schämt sich vor dir fast seiner tauben Narbe.

Wo ende ich? -O Gott!! Denn in die Sterne,

Auch in den Mond sah ich, in alle deiner Früchte Tal.

Der rote Wein wird schon in seiner Beere schal . . .

Und überall-die Bitternis-in jedem Kerne. 
GOD, HEAR...

The night draws in around my eyes

Its ring of haze.

My pulse has sent my blood into a blaze

Though all about me a gray coldness lies.

O God, that I by living day

Should dream I'm dead,

Drink it in water, choke on it in my bread.

There's no measure of my grief your scale can weigh.

God, hear . . . in your own favorite color blue

I sang the song of the roof of your sky-

Yet, in your endless breath, I could not wake the day.

With its dull scar my heart's almost ashamed to come to you.

Where will I end? - O God!! For into the stars,

Also into the moon I looked, into your fruitful vale.

Even in the very berry the red wine grows stale . . .

And everywhere - the bitterness - at the core. 
Auf die jungen Rosensträucher Fällt vom Himmel weicher Regen, Und die Welt wird immer reicher.

O mein Gott mein, nur alleine, Ich verdurste und verweine In dem Segen.

Engel singen aus den Höhen: "Heut ist Gottes Namenstag, Der allweiß hier vom Geschehen . . ."

Und ich kann es nicht verstehen, Da ich unter seinem Dach Oft so traurig erwach.

WEIHNACHTEN

Einmal kommst du zu mir in der Abendstunde Aus meinem Lieblingssterne weich entrückt Das ersehnte Liebeswort im Munde Alle Zweige warten schon geschmückt.

O ich weiß, ich leuchte wieder dann, Denn du zündest meine weißen Lichte an.

"Wann?" - ich frage seit ich dir begegnet- "wann?» Einen Engel schnitt ich mir aus deinem goldenen Haare Und den Traum, der mir so früh zerrann.

$\mathrm{O}$ ich liebe dich, ich liebe dich, Ich liebe dich!

Hörst du, ich liebe dich Und unsere Liebe wandelt schon Kometenjahre, Bevor du mich erkanntest und ich dich. 
Soft the rain and never ceases, Falls from heaven on young roses, And the world's wealth still increases.

O my God, mine, I alone

Die of thirst and always moan In its riches.

From on high the angels sing: "Today's God's birthday celebration, Who all-knows what's happening . . ."

And I cannot understand it, Since so often in His room I awaken full of gloom.

Someday you'll come to me at the hour of eve, Softly rapt away from my favorite star, Speaking the word of love I crave to receive; My branches in their finery watch the door.

Oh, I know that I'll be glowing then, Since you'll light my candles once again.

"When?" —I've been asking since I met you - "when?" I clipped myself an angel from your golden hair And the dream that fled so soon again.

Oh, I love you, I love you,

I love you!

Are you listening, I love you And our love had been wandering on for comets' years Before you recognized me and I you. 
Aus Algenmoos und Muscheln schleichen feuchte Düfte . . . Frohlockend schmiegt die Erde ihren Arm um meine Hüfte.

- Mein Geist hat nach dem Heiligen Geist gesucht-.

Und tauchte auf den Vogelgrund der Lüfte Und grub nach Gott in jedem Stein der Klüfte Und blieb doch Fleisch, leibeigen und verflucht.

Ich keimte schon am Zweig der Liebesgifte, Als noch der Schöpfer durch die Meere schiffte, Das Wasser trennte von der Bucht.

Und alles gut fand, da Er Seine Erde prüfte, Und nicht ein Korn sprießt ungebucht.

Doch Seine beiden Menschen trieb Er in die Flucht! Noch schlief der Weltenplan in Seinem Schöpferstifte. Sie fügten sich nicht Seiner väterlichen Zucht.

Unbändig wie das Feuer zwischen Stein und Stein Noch ungeläutert zu entladen sich versucht, So trotzten sie!! Wie meines Herzens ungezähmte Wucht. 
Damp exhalations creep from shell and weedy sea . . . Around my hip clings the earth's arm, exultantly. -My spirit sought the Holy Spirit's light.

And dipped into the bird-vale of the air, And dug for God in stone cliffs everywhere And yet remained but flesh, in thralldom to the night.

I budded on the branch of love's dread potion, While still the Creator sailed across the ocean, Dividing the water from the bight,

And, when He judged His earth, found good the notion. And not a seed springs up beyond His sight.

Yet did He put His human pair to flight! His pen that planned the world had not yet waked to motion. For they would not submit to His paternal right.

Unruly as the fire between a stone and stone Attempts unpurified to come alight, They bid defiance!

Like the force of my own heart's unbridled spite. 
JERUSA LEM

Gott baute aus Seinem Rückgrat: Palästina

aus einem einzigen Knochen: Jerusalem.

Ich wandele wie durch Mausoleen-

Versteint ist unsere Heilige Stadt.

Es ruhen Steine in den Betten ihrer toten Seen

Statt Wasserseiden, die da spielten: Kommen und Vergehen.

Es starren Gründe hart den Wanderer an-

Und er versinkt in ihre starren Nächte.

Ich habe Angst, die ich nicht überwältigen kann.

Wenn du doch kämest. . . .

Im lichten Alpenmantel eingehüllt-

Und meines Tages Dämmerstunde nähmest-

Mein Arm umrahmte dich, ein hilfreich Heiligenbild.

Wie einst wenn ich im Dunkel meines Herzens litt-

Da deine Augen beide: blaue Wolken.

Sie nahmen mich aus meinem Trübsinn mit.

Wenn du doch kämest-

In das Land der Ahnen-

Du würdest wie ein Kindlein mich ermahnen:

Jerusalem-erfahre Auferstehen!

Es grüßen uns

Des "Einzigen Gottes " lebendige Fahnen,

Grünende Hände, die des Lebens Odem säen. 
JERUS A LEM

God built out of His spine: Palestine

out of a single bone: Jerusalem

They are like mausoleums where I stray-

Our Holy City has turned to stone.

Stones rest in the beds where once its dead lakes lay

Instead of the water-silks that played there: come and pass away.

Beneath the wanderer the hard valleys lower-

And he sinks downward in their rigid nights.

I feel a fear I cannot overpower.

If you but came. . . .

With your bright Alpine mantle wrapped around you-

And took the twilight hour of my day-

For your helpful, saintly icon my arm would be a frame.

Like once when I was suffering in the darkness of my heart-

Since both your eyes: blue clouds.

They took me away from my gloominess.

If you but came-

To the forefathers' land-

You would admonish me just like a child:

Jerusalem-experience resurrection!

We're greeted by

The living flags of the "Only God,"

Greening hands that sow the breath of life. 
AN MEIN KIND

Immer wieder wirst du mir

Im scheidenden Jahre sterben, mein Kind,

Wenn das Laub zerfließt

Und die Zweige schmal werden.

Mit den roten Rosen

Hast du den Tod bitter gekostet,

Nicht ein einziges welkendes Pochen

Blieb dir erspart.

Darum weine ich sehr, ewiglich. . . .

In der Nacht meines Herzens.

Noch seufzen aus mir die Schlummerlieder,

Die dich in den Todesschlaf schluchzten,

Und meine Augen wenden sich nicht mehr

Der Welt zu;

Das Grün des Laubes tut ihnen weh.

-Aber der Ewige wohnt in mir.

Die Liebe zu dir ist das Bildnis,

Das man sich von Gott machen darf.

Ich sah auch die Engel im Weinen,

Im Wind und im Schneeregen.

Sie schwebten .

In einer himmlischen Luft.

Wenn der Mond in Blüte steht

Gleicht er deinem Leben, mein Kind.

Und ich mag nicht hinsehen

Wie der lichtspendende Falter sorglos dahinschwebt.

Nie ahnte ich den Tod

-Spüren um dich, mein Kind- 
TO MY CHILD

Over and over again you'll die Away from me in the parting year, my child.

When the leaves flow down And the branches all turn slender.

Like the rose once red

Death you have tasted bitterly,

You were not spared a single Wilting throb.

That's why I cry aloud, eternally. . . .

In the nighttime of my heart.

The lullabies still come sighing out from me Which sobbed you to death's sleep,

And my eyes no longer turn

Towards the world;

The green of the leaves is hurtful to them.

-But the Eternal One resides in me.

My love of you is the image

That one is allowed to make of God.

I saw the angels weeping too,

In the wind and the snowy rain.

They hovered there ... .

In a heavenly breeze.

When the moon stands blooming

It's like your life, my child.

And I don't want to watch

How the light-shedding butterfly floats carefree on.

I never suspected death

—Scenting you out, my child- 
Und ich liebe des Zimmers Wände,

Die ich bemale mit deinem Knabenantlitz.

Die Sterne, die in diesem Monat

So viele sprühend ins Leben fallen,

Tropfen schwer auf mein Herz.

Ich habe zu Hause ein blaues Klavier Und kenne doch keine Note.

Es steht im Dunkel der Kellertür, Seitdem die Welt verrohte.

Es spielen Sternenhände vier -Die Mondfrau sang im BooteNun tanzen die Ratten im Geklirr.

Zerbrochen ist die Klaviatür. . . . Ich beweine die blaue Tote.

Ach liebe Engel öffnet mir - Ich aß vom bitteren BroteMir lebend schon die HimmelstürAuch wider dem Verbote. 
And I love the walls of the room,

Which I am painting with your boyish face.

The stars that in this month

So many sparkling fall in life

Drop heavy on my heart.

MY BLUE PIANO

I have at my house still a blue piano And yet cannot play a note.

In the dark of the cellar door it stands

Since the world filled with brutal folk.

Star-hands four are playing there

- The moon-woman sang in the boat-

Now the rats are dancing in its blare.

The keyboard is broken beyond repair. . . .

I weep for the blue departed.

Ah, open to me, angels fair,

-I ate of the bitter bread-

To me, still living, heaven's door-

Though it be prohibited. 
GEBET

Oh Gott, ich bin voll Traurigkeit. . . .

Nimm mein Herz in deine Hände-

Bis der Abend geht zu Ende

In steter Wiederkehr der Zeit.

Oh Gott, ich bin so müd, oh, Gott, Der Wolkenmann und seine Frau

Sie spielen mit mir himmelblau

Im Sommer immer, lieber Gott.

Und glaube unserm Monde, Gott, Denn er umhüllte mich mit Schein, Als wär ich hilflos noch und klein, -Ein Flämmchen Seele.

Oh, Gott und ist sie auch voll FehleNimm sie still in deine Hände. . . .

Damit sie leuchtend in dir ende. 
PRAYER

O God, I'm full of dull concern. . . .

Take my heart into your hands-

Until the evening finally ends

In time's continual return.

O God, I am so tired, oh, God, The cloudman and his goodwife too They're playing with me heavenly blue Always in summer, dearest God.

And please believe our moon, O God, For he has bundled me in light

As if I were small and helpless quite, -A little flame of soul.

O God, though it of fault be full-

Take it quietly in your hand. . . .

That, in you, it may gleam-and end. 
OUVERTÜ RE

Wir trennten uns im Vorspiele der Liebe. . . .

An meinem Herzen glitzerte noch hell dein Wort, Und still verklangen wir im Stadtgetriebe, Im Abendschleier der Septembertrübe In einem schluchzenden Akkord.

Doch in der kurzen Liebesouvertüre Entschwanden wir von dieser Erde fort Durch Paradiese bis zur HimmelstüreUnd es bedurfte nicht der ewigen Liebesschwüre Und nicht der Küsse blauer Zaubermord. Und meiden doch seitdem uns wie zwei Diebe! Und nur geheim betreten wir den Ort, Wo uns vergoldete die Liebe.

Bewahren wir sie, daß sie nicht erfriere Oder im Alltag blinder Lust verdorrt.

Ich weinte bitterlich wenn ich es einst erführe- 
OVERTURE

We parted early in the game of love. . . . Your word still glittered brightly on my heart, And, silent, we faded in the city's horde, In dull September's evening veil With a sobbing, musical accord. And yet in that brief overture of love We vanished from this earth entire away Through paradises up to heaven's doorAnd felt no need, nor love-eternal swore, Nor did blue magic murder in a kiss.

And still we avoid each other since like thieves!

And the place love gilded us with bliss We enter only by a secret way.

Let us preserve our love, that it not freeze

Or fade, in the blind pleasure of everyday.

$I^{\prime} d$ weep bitter tears if it ever turned out that way. 
DIE VERSCHEUCHTE

Es ist der Tag im Nebel völlig eingehüllt, Entseelt begegnen alle Welten sich-

Kaum hingezeichnet wie auf einem Schattenbild.

Wie lange war kein Herz zu meinem mild . . .

Die Welt erkaltete, der Mensch verblich.

-Komm bete mit mir-denn Gott tröstet mich.

Wo weilt der Odem, der aus meinem Leben wich?

Ich streife heimatlos zusammen mit dem Wild

Durch bleiche Zeiten träumend-ja ich liebte dich. . . .

Wo soll ich hin, wenn kalt der Nordsturm brüllt?

Die scheuen Tiere aus der Landschaft wagen sich

Und ich vor deine Tür, ein Bündel Wegerich.

Bald haben Tränen alle Himmel weggespült, An deren Kelchen Dichter ihren Durst gestilltAuch du und ich. 
The day's quite shrouded in with fog and wet.

The worlds all meet each other lifelesslyBarely outlined, as in a silhouette.

How long no heart has treated mine with care . . . The world became quite cold, and mankind paled. - Come pray with me-God comforts my despair.

The spirit that fled my life, where does it dwell? Homeless I rove together with the deer Through pale times dreaming-yes, I loved you well. . . .

Where shall I go, when the cold north wind roars?

Out of the landscape shy things venture forth And I before your door, a clump of wayside flowers.

My tears will soon have washed away the sky Whose chalices once stilled the poets' thirstAnd you and I. 
HINGABE

Ich sehe mir die Bilderreihen der Wolken an, Bis sie zerfließen und enthüllen ihre blaue Bahn.

Ich schwebte einsamlich die Welten all hinan, Entzifferte die Sternoglyphen und die Mondeszeichen um den Mann.

Und fragte selbst mich scheu, ob oder wann Ich einst geboren wurde und gestorben dann?

Mit einem Kleid aus Zweifel war ich angetan, Das greises Leid geweiht für mich am Zeitrad spann.

Und jedes Bild, das ich von dieser Welt gewann, Verlor ich doppelt, und auch das was ich ersann.

ICH WEISS

Ich weiß, daß ich bald sterben muß Es leuchten doch alle Bäume Nach langersehntem Julikuß-

Fahl werden meine TräumeNie dichtete ich einen trüberen Schluß In den Büchern meiner Reime.

Eine Blume brichst du mir zum GrußIch liebte sie schon im Keime.

Doch ich weiß, daß ich bald sterben muß.

Mein Odem schwebt über Gottes FlußIch setze leise meinen Fuß Auf den Pfad zum ewigen Heime. 
DEVOTION

I keep the rows of pictures in the clouds in view Until they flow apart and show their path of blue.

Up toward the universe I floated lonely on Deciphered the staroglyphs and signs on the man in the moon.

And even shyly asked myself, both if and when I had been born sometime and then had died again?

I was attired in garments made of doubt

That hoary pain for me on time's great wheel spun out.

And every picture of the world that I could find Doubly I lost, even those made in my mind.

I KNOW

I know I must soon die

For all the trees are set aglow

After the kiss, long longed for, of July-

Pale and paler my dreams grow-

In the volumes of my rhymes

Never a gloomier end I know.

You picked a flower to bring your greeting by-

I loved it even as a seed below.

But I know I must soon die.

My breath is hovering above God's flow-

Homeward to forever, I

Softly set my foot to go. 
HERBST

Ich pflücke mir am Weg das letzte Tausendschön. . . .

Es kam ein Engel mir mein Totenkleid zu nähen-

Denn ich muß andere Welten weiter tragen.

Das ewige Leben dem, der viel von Liebe weiß zu sagen.

Ein Mensch der Liebe kann nur auferstehen!

Haß schachtelt ein! wie hoch die Fackel auch mag schlagen.

Ich will dir viel viel Liebe sagen-

Wenn auch schon kühle Winde wehen,

In Wirbeln sich um Bäume drehen,

Um Herzen, die in ihren Wiegen lagen.

Mir ist auf Erden weh geschehen. . . .

Der Mond gibt Antwort dir auf deine Fragen.

Er sah verhängt mich auch an Tagen,

Die zaghaft ich beging auf Zehen. 
I pick beside the path the last daisy that unfurls. . . .

To sew my burial shroud an angel came to me-

For I must go on bearing other worlds.

Eternal life to him who can say much of love.

A being of love will rise most certainly!

Hate boxes in! High though the torch may flare above.

Much love, much love to you I'll say-

Even if there should blow a chilly breeze,

Turning in whirls about the trees,

Around the hearts that in their cradles lay.

On earth much hurt was done to me. . . .

The moon will answer questions you may raise.

He saw me even veiled on days

Which I traversed on tiptoe, timidly. 
DEM VERKLARTEN

Ach bitter und karg war mein Brot, Verblichen-

Das Gold meiner Wangen Bernstein.

In die Höhlen schleiche ich

Mit den Pantern

In der Nacht.

So bange mir in der Dämmerung Weh . . .

Legen sich auch schlafen

Die Sterne auf meine Hand.

Du staunst über ihr Leuchten-

Doch fremd dir die Not

Meiner Einsamkeit.

Es erbarmen sich auf den Gassen

Die wilden Tiere meiner.

Ihr Heulen endet in Liebesklängen.

$\mathrm{Du}$ aber wandelst entkommen dem Irdischen

Um den Sinai lächelnd verklärt-

Fremdfern vorüber meiner Welt. 
TO MY TRANSFIGURED FRIEND

Ah bitter and scanty was my bread,

Pale as death-

The gold of my cheeks was amber.

Into the caves I creep

With panthers

In the night.

So anxious I in the twilight's sorrow . . .

Even if the stars lie down

On my hand to sleep.

You're surprised by their gleam-

But the pain of my loneliness

Is a stranger to you.

Wild animals in the streets

Take pity upon me.

Their howling ends in sounds of love.

You, though, wander freed of such earthly things

Around Sinai, smiling, radiant-

Strange, far past my world. 
Komm zu mir in der Nacht-wir schlafen engverschlungen.

Müde bin ich sehr, vom Wachen einsam.

Ein fremder Vogel hat in dunkler Frühe schon gesungen,

Als noch mein Traum mit sich und mir gerungen.

Es öffnen Blumen sich vor allen Quellen

Und färben sich mit deiner Augen Immortellen. . . .

Komm zu mir in der Nacht auf Siebensternenschuhen

Und Liebe eingehüllt spät in mein Zelt.

Es steigen Monde aus verstaubten Himmelstruhen.

Wir wollen wie zwei seltene Tiere liebesruhen

Im hohen Rohre hinter dieser Welt. 
Come to me in the night-close interlaced we'll lie. I'm lonely from waking and tired as I can be.

Already in early darkness a strange bird has given cry, While yet my dream did battle with itself and me.

At the springs the opening flowers take on the hue Of your eyes' periwinkle blue. . . .

Come to me in the night in seven-star shoes And robed in love, and late into my tent. Out of the dusty trunks of heaven bright moons suffuse.

Like two rare animals we'll love-rest, curled Here in the high reeds behind the world. 
In meinem Schoße

Schlafen die dunkelen Wolken-

Darum bin ich so traurig, du Holdester.

Ich muß deinen Namen rufen

Mit der Stimme des Paradiesvogels

Wenn sich meine Lippen bunt färben.

Es schlafen schon alle Bäume im GartenAuch der nimmermüde

Vor meinem Fenster-

Es rauscht der Flügel des Geiers Und trägt mich durch die Lüfte Bis über dein Haus.

Meine Arme legen sich um deine Hüften, Mich zu spiegeln

In deines Leibes Verklärtheit.

Lösche mein Herz nicht aus-

Du den Weg findest-

Immerdar. 
In my lap

Sleep the darkening clouds-

Wherefore I am so sad, sweet man.

I must cry out your name

With the voice of the Bird of Paradise,

When my lips flush brightly.

All the trees of the garden have gone to sleepThe tireless one too

In front of my window-

The wing of the vulture rushes

Bearing me through the winds

Above your home.

My arms clasp round your hips

To seek reflection

In your body's refulgent light.

Don't extinguish my heart-

You'll find the way-

Forever. 
DEM HOLDEN

Ich taumele über deines Leibes goldene Wiese, Es glitzern auf dem Liebespfade hin die Demantkiese Und auch zu meinem Schoße Führen bunterlei Türkise.

Ich suchte ewig dich-es bluten meine Füße-

Ich löschte meinen Durst mit deines Lächelns Süße.

Und fürchte doch, daß sich das Tor

Des Traumes schließe.

Ich sende dir, eh ich ein Tropfen frühes Licht genieße, In blauer Wolke eingehüllte Grüße

Und von der Lippe abgepflückte eben erst erblühte Küsse.

Bevor ich schwärmend in den Morgen fließe. 
TO THE DEAR ONE

Over your body's golden fields I run and play; The diamond gravel glitters all along love's way, And likewise to my womb Turquoise of many colors leads the way.

I searched for you forever-with bleeding feetI fed my hunger on your smile's red sweet.

And yet I am afraid the dream Will bar its gate.

I send you, before I drink a drop of dawn, My greetings with blue clouds around them drawn, And just-bloomed kisses plucked off of my lips Before I flow enraptured toward the morn. 
DIE UNVOLLENDETE

Es ist so dunkel heut am Heiligen Himmel. . . .

Ich und die Abendwolken suchen nach dem MondWo beide wir einst vor dem Erdenleben, Schon nahe seiner Leuchtewelt gewohnt.

Darum möcht ich mit dir mich unlösbar verwebenIch hab so Angst um Mitternacht! Es schreckt ein Traum mich aus vergangenem Leben An den ich gar nicht mehr gedacht.

Ich pflückte mir so gern nach banger Nacht Vom Berg der Frühe lichtgefüllte Reben.

Doch hat die Finsternis mich umgebrachtGeopfert deinem Wunderleben.

Und es verblutet, was du mir, Ich dir gegeben, Und auch das bunte Sternenzeichen Unserer engverknüpften Hand, Das Pfand!!

Und neben mir und deinAuf meinem Herzen süßgemalt enthobnem Sein - Tröstet mich ein Fremder übermannt.

Ihm mangelt an der Ouvertüre süßem Tand Streichelnder Flüsterspiele seiner Triebe, Verherrlichend den keuschen Liebeskelch der Liebe. 
It is so dark today in the Sacred Skies. . . .

I and the evening clouds look for the moon-

Where both of us once, before our earthly lives,

Lived close to the gleaming world that it illumed.

That's why I'd like, indissolubly, to weave myself to you.

At midnight my fears are overwrought!

A dream strikes terror in me, from a life long through,

Of which I had no longer thought.

After a frightened night I loved to gather,

In the vineyards of the dawn, grapes full of light.

But I have been murdered by the dreadful darkness

To your miraculous life a sacrifice.

And what you gave me, and I you,

Has bled to death

And, too, the colorful starry signs

Of our close-twining hand,

Our pledge's band!!

And next to me and your

Suspended being, sweet-painted on my heart,

-A stranger reconciles me thus outmanned.

He's lacking in the overture's sweet, trifling art,

Caressing whisper-games of his desires,

That glorify the chaste cup of love's fires. 
AN APOLLON

Es ist am Abend im April.

Der Käfer kriecht ins dichte Moos.

Er hat so Angst-die Welt so groß!

Die Wirbelwinde hadern mit dem Leben,

Ich halte meine Hände still ergeben

Auf meinem frommbezwungenen Schoß.

Ein Engel spielte sanft auf blauen Tasten,

Langher verklungene Phantasie.

Und alle Bürde meiner Lasten,

Verklärte und entschwerte sie.

Jäh tut mein sehr verwaistes Herz mir wehBlutige Fäden spalten seine Stille.

Zwei Augen blicken wund durch ihre Marmorhülle In meines pochenden Granates See.

Er legte Brand an meines Herzens Lande-

Nicht mal sein Götterlächeln

Ließ er mir zum Pfande. 
TO APOLLO

It is April in the evening.

The beetle creeps his mossy paths;

He's so afraid-the world's so vast!

And Life is a-quarrel with the whirlwinds' commotion.

I fold my hands in still devotion

On knees by piety held fast.

Softly an angel played upon blue keys

Long-faded fantasies,

Which weightlessness and radiance bestowed

On all the burden of my load.

My very orphaned heart abruptly aches-

When bloody threads cut up its quietude.

Two eyes look painfully through its marble hood

Into my pulsating pomegranate's lakes.

He put the torch to my heart's landing placeAnd didn't even leave as pledge

That godlike smile upon his face. 
Meine Dichtungen, deklamiert, verstimmen die Klaviatür meines Herzens. Wenn es noch Kinder wären, die auf meinen Reimen tastend meinetwegen klimperten. (Bitte nicht weitersagen!) Ich sitze noch heute sitzengeblieben auf der untersten Bank der Schulklasse, wie einst . . . Doch mit spätem versunkenem Herzen: 1000 und 2-jährig, dem Märchen über den Kopf gewachsen.

Ich schweife umher! Mein Kopf fliegt fort wie ein Vogel, liebe Mutter. Meine Freiheit soll mir niemand rauben,-sterb ich am Wegrand wo, liebe Mutter, kommst du und trägst mich hinauf zum blauen Himmel. Ich weiß, dich rührte mein einsames Schweben und das spielende Ticktack meines und meines teuren Kindes Herzen. 
TO ME

My poems, declaimed, untune the keyboard of my heart. If only it were children who picked and clinked around on my rhymes-as far as I care. (Don't tell anyone else!) Here I sit still today, having flunked the grade, on the hindmost bench of the class-as once before . . . But with a late, sunken heart! 1000 and 2 years old, the fairy tale now outgrown.

I'm wandering! My head flies away like a bird, dear mother. Nobody will steal my freedom-if I die somewhere by the side of the road, dear mother, you'll come and carry me up to blue heaven. I know that my lonely floating touched you and the playful ticktock of mine and my dear child's heart. 



\section{Identifications}

Barbarian, The: Gottfried Benn, see p. 21.

Baum, Peter: (1869-1916) Like Lasker-Schüler a native of Elberfeld. Author of verse and fiction influenced by Edgar A. Poe and E. T. A. Hoffmann. A member of Peter Hille's circle, see p. 16. Died in World War I.

Daniel Jesus Paul: See Paul Leppin, author of the novel Daniel Jesus.

Duke of Leipzig: See Hans Adalbert von Maltzahn.

Davringhausen, Heinrich Maria: (1894- ) Sculptor, painter, and lithographer of biblical subjects, figures, landscapes, still lifes, and portraits. Portraits masklike, more types than individuals. Style change from expressionist distortion to new objectivity.

Ehrenbaum-Degele, Hans: (1889-1915) Editor with Paul Zech of the periodical The New Pathos (Das neue Pathos) during the years 1913-14. Author of a play and verses. Killed in Russia during World War I.

Giselheer: Gottfried Benn, see p. 21.

Grosz, Georg: (1893-1959) Painter and graphic artist from Berlin, particularly known for political satire directed against capitalism, militarism, the bourgeoisie, and German society's moral decay. Moved to New York in 1932. Participated in American social realism.

King of Bohemia: See Paul Leppin.

Kestenberg, Leo: (1882-1962) Pianist, professor of music in Berlin, and active in cultural education for the Socialist party. As an official in the Prussian Ministry of Culture, he introduced important reforms in music education in the schools. After 1933, exile in Prague, Paris, and Israel.

Leppin, Paul: (1878-1945) Writer of tales, plays, lyrics, and novels, the latter including Daniel Jesus (1905). Professionally an official in Prague.

Marc, Franz: (1880-1916) One of the internationally best-known German expressionist painters, especially for the "Blue Horses" and other animal subjects. Later nonobjective style. Born in Munich; died in World War I.

Monk, The: All poems to the "Monk" are dedicated to "F. J.," perhaps Franz Jung, contributor to the periodical Aktion and author of the novel Sacrifice (Opferung).

Sascha: See Johannes Holzmann, p. 6.

Schmidtbonn, Wilhelm: (1876-1952) Playwright, fiction writer, and lyric poet, born in Bonn. War correspondent in World War I. His first drama marked the transition from naturalism to neoromanticism in Germany. Depicted landscape and people of the Rhineland.

Senna Hoy: Johannes Holzmann, see p. 6.

Steger, Milly: (1881-1948) Sculptress of wood and stone in Berlin. Studied in Paris with Rodin and Maillol. Known for figures of girls, portrait busts, and sculpture on public buildings in Hagen. Teacher at the Women Artists' Club in Berlin.

Trakl, Georg: (1887-1914) Austrian lyric poet, one of the most significant poets of the expressionist movement. Author of melancholy but sonorous poems of a basically elegiac and pessimistic mood. Died of an overdose of drugs while a medic in World War I.

Tristan: See Hans Ehrenbaum-Degele. 


\section{Identifications}

Trübner, Alice: (1875-1916) Born in England; youth in Frankfurt. Painted heads in a monumental relief style, then landscapes, still life, and portraits.

Werfel, Franz: (1890-1945) Expressionist lyric poet from Prague. Proclaimer of the renewal of mankind. Also a dramatist and later particularly known as an historical, religious, and utopian novelist, especially as author of The Song of Bernadette and Star of the Unborn. 


\title{
Else Lasker-Schüler Select Bibliography
}

\begin{abstract}
A bibliography of works by Lasker-Schüler published during her lifetime and after, a comprehensive listing of her artistic works, and a more extensive coverage of critical articles published prior to 1978, will be found in Sigrid Bauschinger, Else Lasker-Schüler: Ihr Werk und ihre Zeit (Heidelberg, 1980). See also the extensive bibliographies in Dieter Bänsch, Else Lasker-Schüler: Zur Kritik eines etablierten Bildes (Stuttgart, 1971), and in Margarete Kupper, Die Weltanschauung Else Lasker-Schülers in ihren poetischen Selbstzeugnissen (Diss., Würzburg, 1963).
\end{abstract}

\section{Select Works and Letters by Else Lasker-Schüler Published since 1950}

"Ein Brief an Thomas Mann." Bulletin of the Leo Baeck Institute (Tel Aviv) 11, no. 42 (1968): 259-64.

Briefe an Karl Kraus. Astrid Gehlhoff-Claes, ed. Cologne-Berlin, n.d.

Briefe, I: Lieber gestreifter Tiger. Margarete Kupper, ed. Munich, 1969.

Briefe, II: Wo ist unser buntes Theben. M. Kupper, ed. Munich, 1969.

Dichtungen und Dokumente: Gedichte, Prosa, Schauspiele, Briefe, Zeugnis und Erinnerung. Ernst Ginsberg, ed. Munich, 1951.

"Drei Briefe." Bulletin of the Leo Baeck Inst. 8, no. 29 (1965): 1-6.

Else Lasker-Schüler: Eine Einführung in ihr Werk und eine Auswahl. Werner Kraft, ed. Wiesbaden, 1951.

Else Lasker-Schüler: Hebrew Ballads and Other Poems, translated by Audri Durchslag and Jeanette Litman-Demeestère. Philadelphia, 1980.

Gedichte und Prosa: Eine Auswahl. Nachwort von Friedrich Mickwitz. Weimar, 1967.

Gesammelte Werke, I: Gedichte, 1902-1943. Friedhelm Kemp, ed. Munich, 1959. II: Prosa und Schauspiele. Friedhelm Kemp, ed. Munich, 1962. III: Verse und Prosa aus dem Nachlaß. Werner Kraft, ed. Munich, 1961.

Gesichte: Essays und andere Geschichten. (Reprint of the edition of 1913.) Nendeln/ Liechtenstein, 1973.

Das Hebräerland. Munich, 1981.

Ichundich: Eine theatralische Tragödie. Munich, 1980.

Mein Herz: Ein Liebesroman mit Bildern. (Reprint of the edition of 1912.) Nendeln/ Liechtenstein, 1973.

Mein Herz: Ein Liebesroman mit Bildern und wirklich lebenden Menschen. Mit Zeichnungen der Autorin aus der Ausgabe von 1912. Frankfurt, 1976.

Der Prinz von Theben: Ein Geschichtenbuch. (Reprint of the edition of 1914.) Nendeln/ Liechtenstein, 1973.

Sämtliche Gedichte. Friedhelm Kemp, ed. Munich, 1977.

Was soll ich hier? Exilbriefe an Salman Schocken. Sigrid Bauschinger, ed. Heidelberg, 1981. Die Wolkenbrücke: Ausgewählte Briefe. Margarete Kupper, ed. Munich, 1972.

Die Wupper-Arthur Aronymus und seine Väter. Munich, 1965.

Die Wupper: Schauspiel in 5 Aufzügen, Mit Dokumenten zur Entstehungs- und Wirkungsgeschichte und einem Nachwort von Fritz Martini. Stuttgart, 1977. 


\section{Bibliography}

\section{Select Secondary Literature on Lasker-Schüler and Her Work}

Ahl, Herbert. "Else Lasker-Schüler." Welt und Wort 18 (1962): 277-80.

Aker, E. Untersuchungen der Lyrik Else Lasker-Schülers. Diss., Munich, 1956.

Auer, Leopold. "Mein blaues Klavier: Zum 25. Todestag Else Lasker-Schülers."

Literatur und Kritik 5, no. 42 (1970): 113-17.

Bänsch, Dieter. Else Lasker-Schüler: Zur Kritik eines etablierten Bildes. Stuttgart, 1971.

Baldrian, Brigitte. Form und Struktur der Bildlichkeit bei Else Lasker-Schüler. Diss., Freiburg i. Breisgau, 1926.

Bauschinger, Sigrid. Else Lasker-Schüler: Ihr Werk und ihre Zeit. Heidelberg, 1980. “Else Lasker-Schüler in ihren Briefen." Neue Rundschau 81 (1970): 366-74. Die Symbolik des Mütterlichen im Werke Else Lasker-Schülers. Stuttgart, 1960. (Diss., Frankfurt/M., 1960.)

Beck, Evelyn Torton. "Franz Kafka and Else Lasker-Schüler: Alienation and Exile, A Psychocultural Comparison." Perspectives on Contemporary Literature 1, no. ii (1975): 31-47.

Ben-Chorin, Schalom. "Else Lasker-Schüler." In his Zwiesprache mit Martin Buber: Ein Erinnerungsbuch, pp. 75-81. Munich, 1966. . "Else Lasker-Schüler und Israel." Literatur und Kritik, no. 105 (1976): 291-97. . "Else Lasker-Schüler zum 100. Geburtstag." Almanach für Literatur und Theologie 3 (1969): 178-92. "Jussuf in Jerusalem." In Ein Buch . . . , edited by Michael Schmid, pp. 55-69. Wuppertal, 1969.

"Prinz Jussuf in Jerusalem." In Else Lasker-Schüler, Dichtungen und Dokumente, edited by Ernst Ginsberg, pp. 582-90. Munich, 1951.

Benn, Gottfried. "Else Lasker-Schüler." In Gottfried Benn: Gesammelte Werke, edited by Dieter Wellershoff, 4:1101-4. Wiesbaden, 1968.

Berg, Herbert. "The Child Faces Crisis: A Study of Thematic Relationships in the Early Poetry of Else Lasker-Schüler and in the Menschheitsdämmerung Anthology." Dissertation Abstracts International 36 (1975): 298A-99A.

Bienek, Horst. "Else Lasker-Schüler." In Triffst du nur das Zauberwort: Stimmen von heute zur deutschen Lyrik, edited by Jürgen Petersen, pp. 186-95. Frankfurt, 1961.

Blei, Franz. "Der Laskerschüler." In his Das große Bestiarium: Schriften in Auswahl, p. 46. Munich, 1960.

Bleyl, Hansjoachim. "Geschichte um die 'Wupper' in der Schaubühne." Neue Deutsche Hefte 23 (1976): 646-50.

Blumenthal, Bernhardt. Aspects of Love in the Life and Works of Else Lasker-Schüler. Diss., Princeton, 1965.

. "The Play Element in the Poetry of Else Lasker-Schüler." German Quarterly 43 (1970): 571-76.

Carr, G. J. "Zu den Briefen Else Lasker-Schülers an Karl Kraus." Literatur und Kritik 5, no. 49 (1970): 549-56.

Cohn, Hans W. Else Lasker-Schüler: The Broken World. Cambridge, 1974. (Anglica Germanica, Series 2.)

David, Claude. "Karl Kraus-Else Lasker-Schüler." Etudes Germaniques 15, no. 4 (1960): 364-68.

Domdey, Horst. Frühe und späte Lyrik Else Lasker-Schülers: Vergleichende Untersuchungen $z u$ Gehalt und Rhythmus. Berlin, 1964. (Diss., Berlin, 1964.)

Dorst, Tankred. "Szene für Else." Emuna 4 (1969): 23.

Dürrson, Werner. "Der Seltsamsaft: Zu Else Lasker-Schülers Einfluß auf die Lyrik von 
Gottfried Benn." In Denken in Widersprüchen: Korrelarien zur Gottfried-BennForschung, edited by Wolfgang Peitz, pp. 184-204. Freiburg i. Breisgau, 1971.

Ficker, Ludwig von. "Die religiöse Bedeutung der Dichterin Else Lasker-Schüler." In Else Lasker-Schüler, Dichtungen und Dokumente, pp. 606-9. Munich, 1951.

Fischer, Grete. Dienstboten, Brecht und andere: Zeitgenossen in Prag, Berlin, London. Olten, Freiburg i. Breisgau, 1966.

Fischer, Heinrich. "Else Lasker-Schüler zum Gedächtnis." In Else Lasker-Schüler, Dichtungen und Dokumente, pp. 601-4. Munich, 1951.

Gehlhoff-Claes, Astrid. "Versuch einer biographischen Darstellung." In Briefe an Karl Kraus, edited by A. Gehlhoff-Claes, pp. 141-76. Cologne-Berlin, 1959. (Separately printed as Folge 2 of the "Wuppertaler Biographien," 1960.)

Gertner, Meier. "Biblische Spiegelbilder." In Ein Buch . . . , edited by Michael Schmid, pp. 166-82. Wuppertal, 1969.

Ginsberg, Ernst. "Else Lasker-Schüler." In his Abschied, pp. 153-66. Zurich, 1965. "Es steigen aus verstaubten Himmelstruhen." Frankfurter Allgemeine Zeitung, no. 13 (1965).

ed. Else Lasker-Schüler, Dichtungen und Dokumente: Gedichte, Prosa, Schauspiele, Briefe, Zeugnis und Erinnerung. Munich, 1951.

Goetz, Markete. "Else Lasker-Schüler's Play Die Wupper: A Forerunner of Contemporary Drama." Proceedings of the Pacific Northwest Conference on Foreign Languages, Sixteenth Annual Meeting, April 22-24, 1965, pp. 101-8.

Goldscheider, Paul. "Wo ich bin, ist es grün." In Ein Buch . . . , edited by Michael Schmid, pp. 50-54. Wuppertal, 1969.

Goldstein, Fanni. Der expressionistische Stilwelle im Werke Else Lasker-Schülers. Diss., Vienna, 1936.

Gottgetreu, Erich. "Else Lasker-Schüler und 'der Urböse.'" Emuna 4 (1969): 246-48. "Näher heran an Else Lasker-Schüler." Neue Deutsche Hefte 168 (1980): 797-801.

Grosshut, F. S. "Else Lasker-Schüler in der Emigration." In Ein Buch . . . , edited by Michael Schmid, pp. 590-93. Wuppertal, 1969.

Guder, Gotthard. Else Lasker-Schüler: Deutung ihrer Lyrik. Siegen, 1966. "Else Lasker-Schüler's Conception of Herself as a Poet." Orbis Litterarum 15, no. 3/4 (1960): 184-99. . "The Image of the Angel in the Poetry of Else Lasker-Schüler." Modern Languages 47 (1966): 98-103. . "The Meaning of Colour in Else Lasker-Schüler's Poetry." German Life and Letters 15 (1961): 175-87. "The Poetry of Else Lasker-Schüler." Modern Languages 43 (1962): 53-60. "The Significance of Love in the Poetry of Else Lasker-Schüler." German Life and Letters 18 (1965): 177-88.

Hegglin, Werner. Else Lasker-Schüler und ihr Judentum. Zurich, 1966.

Hermlin, Stephan. Lektüre, 1960-1971. Frankfurt/M., 1974.

Herzfelde, Wieland. "Else Lasker-Schüler: Begegnungen mit der Dichterin und ihrem Werk." Sinn und Form 21 (1969): 1294-325.

"Fremd und Nah: Über meinen Briefwechsel und meine Begegnungen mit Else

Lasker-Schüler." Marginalien: Blätter der Pirckheimer Gesellschaft, no. 18 (1965): 1-7. "Kürzlich vor 60 Jahren." Sinn und Form 27 (1975): 371-84.

Zur Sache geschrieben und gesprochen zwischen 18 und 80. Berlin, 1976.

Heselhaus, Clemens. "Else Lasker-Schülers literarisches Traumspiel." In his Deutsche Lyrik der Moderne, pp. 213-28. Düsseldorf, 1961.

Hessing, Jakob. “Else Lasker-Schüler and Her People." Ariel 41 (1976): 61-76. 
Hirshberg, Jehoash. "Joseph Tal's Homage to Else." Ariel 41 (1976): 83-93.

Höltgen, K. J. Untersuchungen zur Lyrik Else Lasker-Schülers. Bonn, 1958. (Diss., Bonn, 1955.)

Jais, Agathe. Else Lasker-Schüler: Die Lyrik der mittleren Schaffensperiode. Diss., Munich, 1965.

Jung, Cläre M. "Bilder meines Lebens" (Two parts). Neue Deutsche Literatur, 19, no. 2 (1971): 114-31; and 20, no. 4 (1972): 109-22.

Kesting, Marianne. "Else Lasker-Schüler und ihr blaues Klavier." Deutsche Rundschau, no. 83 (1957): 66-70.

. "Zur Dichtung Else Lasker-Schülers." Akzente 3 (1956): 377-83.

Klotz, Volker. "Das blaue große Bilderbuch mit Sternen." In his Kurze Kommentare zu Stücken und Gedichten, pp. 61-70. Darmstadt, 1962.

Klüsener, Erika. Else Lasker-Schüler in Selbstzeugnissen und Bilddokumenten. Hamburg, 1980.

. "Else Lasker-Schüler: Eine Biographie oder ein Werk?" Dissertation Abstracts International 40 (1980): 4068A-69A.

Koch, Angelika. Die Bedeutung des Spiels bei Else Lasker-Schüler im Rahmen von Expressionismus und Manierismus (Abhandlungen zur Kunst-, Musik- und Literaturwissenschaft, 107). Bonn, 1971.

Kraft, Werner. "Else Lasker-Schüler." In Juden, Christen, Deutsche, edited by Hans Jürgen Schulz, pp. 380-88. Stuttgart, 1961.

. "Erinnerungen an Else Lasker-Schüler." Hochland 43, no. 6 (1951): 588-92.

. Else Lasker-Schüler: Eine Einführung in ihr Werk und eine Auswahl. Wiesbaden, 1951.

Kraus, Karl. "Anmerkung zum "Tibetteppich.'" Die Fackel 12, nos. 313-14 (1910): 36.

"Der Reim." In Else Lasker-Schüler, Dichtungen und Dokumente, edited by Ernst Ginsberg, pp. 570-72. Munich, 1951.

Kunz, Ludwig. "Verse bei Kerzenlicht." In Ein Buch . . . , edited by Michael Schmid, pp. 70-72. Wuppertal, 1969.

Kupper, Margarete. "Lebenslauf." In Else Lasker-Schüler: Sämtliche Gedichte, edited by Friedhelm Kemp, pp. 291-310. Munich, 1966.

"Materialien zu einer kritischen Ausgabe der Lyrik Else Lasker-Schülers." Jahrbuch der Görres-Gesellschaft, Neue Folge 4 (1963): 95-190.

"Der Nachlaß Else Lasker-Schülers in Jerusalem: Ein Bericht." Jahrbuch der Görres-Gesellschaft 9 (1968): 243-83.

"Der Nachlaß Else Lasker-Schülers in Jerusalem, II. Verzeichnis der Briefe an Else Lasker-Schüler" (Mit Textabdruck). Jahrbuch der Görres-Gesellschaft 10 (1969): 175-230.

. "Der Nachlaß Else Lasker-Schülers, III. Epistolographie (1): Register der veröffentlichten und der unveröffentlichten Briefe von Else Lasker-Schüler." Jahrbuch der Görres-Gesellschaft 11 (1970): 225-83.

"Der Nachlaß Else Lasker-Schülers, III. Epistolographie (2): Korrektur der

Briefdrucke. Auswahl bisher unveröffentlichter Briefe von Else Lasker-Schüler"

(Mit Textpublikationen). Jahrbuch der Görres-Gesellschaft 12 (1971): 241-91.

Die Weltanschauung Else Lasker-Schülers in ihren poetischen Selbstzeugnissen. Diss.,

Würzburg, 1963.

"Wiederentdeckte Texte Else Lasker-Schülers." Jahrbuch der Görres-Gesellschaft

5 (1964): 229-63.

"Wiederentdeckte Texte, II." Jahrbuch der Görres-Gesellschaft 6 (1965): 227-33. 
" "Wiederentdeckte Texte, III. Aus dem Lasker-Schüler-Archiv in Jerusalem." Jahrbuch der Görres-Gesellschaft 8 (1967): 175-99.

. "Ein wiederentdecktes Gedicht von Else Lasker-Schüler." Germanisch-

romanische Monatsschrift, Neue Folge 13 (1963): 80-91.

, ed. "Ichundich: Nachlaßschauspiel von Else Lasker-Schüler." Jahrbuch der deutschen Schiller-Gesellschaft 14 (1970): 24-99.

Laube, Horst. "Nur eine originelle Blüte?" In Ein Buch . . . , edited by Michael Schmid, pp. 114-22. Wuppertal, 1969.

Lienau, Marianne. "Anarchie nach innen." In Ein Buch . . . , edited by Michael Schmid, pp. 101-11. Wuppertal, 1969.

Lindtberg, Leopold. "So glänzte der Traum des Arthur Aronymus." In Ein Buch . . . , edited by Michael Schmid, pp. 73-86. Wuppertal, 1969.

Macht, Richard M. "Motifs of Judaic Mysticism in the Poetry of Else Lasker-Schüler." Dissertation Abstracts 29 (1969): 3146A-47A.

Marc, Franz. Briefe, Aufzeichnungen und Aphorismen. Berlin, 1920.

Marc, M. Franz Marc: Botschaften an den Prinzen Jussuf. Munich, 1954.

Marsch, Edgar. "Else Lasker-Schüler." In Deutsche Dichter der Moderne: Ihr Leben und Werk, edited by Benno von Wiese, pp. 365-88. 2nd. ed. Berlin, 1969.

Martini, Fritz. "Else Lasker-Schüler." In his Was war Expressionismus? pp. 107-11. Urach, 1948.

. "Else Lasker-Schüler: Dichtung und Glaube." In Der deutsche Expressionismus: Formen und Gestalten, edited by Hans Steffen, pp. 5-24. Göttingen, 1965.

Masini, Ferruccio. Itinerario sperimentale nella letteratura tedesca. Parma, 1970.

Meyer, André. "Vorahnungen der Judenkatastrophe bei Heinrich Heine und Else Lasker-Schüler." Bulletin of the Leo Baeck Institute 8, no. 29 (1965): 7-27.

Muschg, Walter. "Else Lasker-Schüler." In his Von Trakl zu Brecht: Dichter des Expressionismus, pp. 115-48. Munich, 1961.

Nachrichten aus dem Kösel-Verlag. (Sonderheft) Für Else Lasker-Schüler. Munich, 1965.

Newton, Robert. "Eye Imagery in Else Lasker-Schüler." Modern Language Notes 97 (1982): 694-712.

Otto, Teo. "Ein bergischer Kräher berichtet." In Ein Buch . . . , edited by Michael Schmid, pp. 41-49. Wuppertal, 1969.

Paepcke, Lotte. "Else Lasker-Schüler." Frankfurter Hefte 16 (1961): 33-40.

Pazi, Margarita. "Else Lasker-Schüler in Jerusalem: Zur Nuancierung einer allgemeinen Meinung." Deutsche Vierteljahresschrift für Literaturwisseschaft und Geistesgeschichte 53 (1979): 115-24.

Pörtner, Paul. "Poesie lebte." In Ein Buch . . . , edited by Michael Schmid, pp. 183-93. Wuppertal, 1969.

Politzer, Heinz. “The Blue Piano of Else Lasker-Schüler." Commentary 9, no. 4 (1950): 336.

. "Else Lasker-Schüler." In Expressionismus als Literatur: Gesammelte Studien, edited by Wolfgang Rothe, pp. 215-32. Bern and Munich, 1969.

Raabe, Paul. "Gottfried Benns Huldigungen an Else Lasker-Schüler. Unbekannte Dokumente des Dichters, 1931-32." In Gottfried Benn. .Den Traum alleine tragen. Texte, Briefe, Dokumente, edited by Paul Raabe and Max Niedermayer, pp. 61-79. Wiesbaden, 1966.

Radecki, Sigismund von. "Erinnerungen an Else Lasker-Schüler." In Else LaskerSchüler: Dichtungen und Dokumente, edited by Ernst Ginsberg, pp. 575-82. Munich, 1951. 


\section{Bibliography}

Rosenfeld, Emmy. "Wanderer zwischen den Welten (Else Lasker-Schüler und Franz Werfel)." In Studi e ricerche di letteratura inglese e americana, edited by Claudio Gorlier, 2:259-86. Milan, 1969.

Rost, Nico. "Ontmoetingen met Prins Tino van Bagdad." De Vlaamse Gids 49 (1965): 331-36.

Schlocker, Georges. "Else Lasker-Schüler." In Expressionismus: Gestalten einer literarischen Bewegung, ed. H. Friedmann and O. Mann, pp. 140-54. Heidelberg, 1956.

. “Exkurs über Else Lasker-Schüler." In Deutsche Literatur im 20. Jahrhundert, ed.

O. Mann and W. Rothe, vol. 1: 344-57. Bern and Munich, 1967.

Schlösser, Manfred. "Deutsch-jüdische Dichtung des Exils." Emuna 3 (1968), 250-65.

Schmid, Michael. "Else Lasker-Schüler. Eine Biographie." In Ein Buch . . . , edited by Michael Schmid, pp. 7-40. Wuppertal, 1969.

, ed. Else Lasker-Schüler: Ein Buch zum 100. Geburtstag der Dichterin. Wuppertal, 1969.

"Schwierigkeiten mit Arthur Aronymus." Emuna 4 (1969): 257-58.

Springmann, Wolfgang. "Else Lasker-Schüler und ihre Wuppertaler Heimat." Emuna 4 (1969): 15-22.

. Else Lasker-Schüler und Wuppertal: Auswahl und Kommentar von Wolfgang

Springmann, Neue verbesserte Auflage. Wuppertal-Elberfeld, 1965. (Veröf-

fentlichungen der Stadtbibliothek Wuppertal, VI.)

Sturmann, M. “Briefe an Else Lasker-Schüler, zur Einführung." Bulletin of the Leo Baeck Institute 2, no. 7 (1959): 162-66.

Sull, Young Suk. "Die Lyrik Else Lasker-Schülers: Stilelemente und Themenkreise." Dissertation Abstracts International 41 (1980): 269A.

Thiel, Heinz. "Ich und Ich: Ein versperrtes Werk?" In Ein Buch . . , , edited by Michael Schmid, pp. 123-59. Wuppertal, 1969.

Wallmann, Jürgen. "Ein alter Tibetteppich." Neue Deutsche Hefte 11, no. 102 (1964): 63-69.

"Deutsche Lyrik unter jüdischem Dreigestirn." Merkur 20, no. 12 (1966): 1191-94.

Else Lasker-Schüler. Mühlacker, 1966.

"Hommage für Else Lasker-Schüler." In Ein Buch . . . , edited by Michael Schmid, pp. 195-204. Wuppertal, 1969.

Webb, Karl E. "Else Lasker-Schüler and Franz Marc: A Comparison." Orbis Litterarum 33 (1978): 280-98.

Weidmann, Brigitte. "Else Lasker-Schüler: Zum 25. Todestag am 22.1.1970." Neue Deutsche Hefte 17, no. 1 (1970): pp. 18-27.

Weiß, Richard. “Else Lasker-Schüler.” Die Fackel 13, no. 321/22 (1911): 42-50.

Weissenberger, Klaus. Zwischen Stein und Stern: Mystische Formgebung in der Dichtung von Else Lasker-Schüler, Nelly Sachs und Paul Celan. Bern and Munich, 1976.

Wegner, Armin T. "Unser Kaffeehaus oder die Arche." In Ein Buch . . . , edited by Michael Schmid, pp. 87-99. Wuppertal, 1969.

Werner, Gerhart. "Tinos großer Bruder." In Ein Buch . . . , edited by Michael Schmid, pp. 160-65. Wuppertal, 1969.

Windfuhr, Manfred. Die unzulängliche Gesellschaft: Rheinische Sozialkritik von Spee bis Böll. (Mit 13 Abb.). Stuttgart, 1971.

Zimmermann, Inge M. E. "Der Mensch im Spiegel des Tierbildes: Untersuchungen zum Werk Else Lasker-Schülers." Dissertation Abstracts International 41 (1980): 2132A-33A. 


\section{Index of Poem Titles}

(Bold face refers to English text.)
Abdul Antinous, 199

Abel, 249

Abraham and Isaac, 41, 49, 251

After-Pain, 30, 91

Alice Trübner, 38, 221

And Look for God, 139

Antinous, 239

Arrival, 131

Autumn, 31, 43, 289

Baboon Mother Sings Her Baboonlet to Sleep, The, 20, 239

Ballad (From the Mountains of the Sauerland), 23, 33, 85

Ballad, 20, 147

Black Stars, 105

But Your Brows Are a Storm, 37, 187

Chaos, 30, 45, 71

Chased Away, 25, 49, 285

Christmas, 271

Damnation, 30, 43, 73

David and Jonathan, 261

David and Jonathan, 33, 49, 263

Departure, 265

Devotion, 287

"Dove That Swims in Its Own Blood," 34,113

Dream, 111

Elegy, 33, 43, 93

End of the World, The, 34, 43, 131

Esther, 49, 263

Eve, 115

Evening Song, 271

Eve's Song, 121

Fallen Angel, The, 16, 30, 76

Fear Deep in My Blood, The, 30, 45, 99

Flight from the World, 44, 57

Flight of Love, 33, 111

Fortissimo, 31, 33, 49, 77

Franz Marc, 23, 235

Franz Werfel, 215
Genesis, 49, 273

Georg Grosz, 223

Georg Trakl, 219

Georg Trakl, 49, 219

God Hear . . . , 43, 269

Grotesque, 34, 119

Guilt, 30, 89

Hagar and Ishmael, 253

Hans Ehrenbaum-Degele, 159

Heinrich Maria Davringhausen, 225

His Blood, 33, 67

Homesickness, 141

I Am Sad, 39, 137

I Hide behind Trees, 22, 171

I Know, 26, 287

In My Lap, 295

Instinct, 30, 33, 59

In the Beginning (World Scherzo), 43, 101

Jacob, 40, 255

Jacob and Esau, 253

Jerusalem, 42, 275

Karma, 33, 65

Knowledge, 33, 107

Leave-Taking, 9, 193

Leave-Taking, 203

Leo Kestenberg, 229

Listen, 22, 175

Love Song, A, 20, 40, 151

Love Song, A, 31, 49, 293

Love Stars, 105

Ludwig Hardt, 231

Mary of Nazareth, 145

May Rain, 123

May Roses, 63

Milly Steger, 227

Monk, The, 205

Moses and Joshua, 41, 49, 259

My Being, 103

My Blue Piano, 49, 279 


\section{Index of Poem Titles}

My Child, 19, 237

My Drama, 33, 175

My Love Song, 129

My Love Song, 20, 149

My Mother, 13, 143

My People, 41, 247

My Quiet Song (first version), 13, 34, 125

My Quiet Song (second version), 13, 241

O God, 22, 175

Oh, Your Hands, 22, 163

Old Spring, 30, 33, 49, 61

Old Tibetan Rug, An, 21, 35, 137

Only for.You, 22, 179

Our Battle Song, 117

Our Love Song, 197

Our Proud Song, 115

Overture, 238

Pablo, 201

Peter Baum, 217

Pharaoh and Joseph, 33, 35, 49, 257

Prayer, 23, 39-40, 49, 243

Prayer, 43, 46, 49, 281

Pure Diamond, 22, 167

Reconciliation, 38, 39, 49, 245

Royal Will, 87

Sabaoth, 265

Sascha, 20, 155

Savary Le Duc, 195

Say It Softly, 38-39, 135

School Days, 34, 119

Secretly at Night, 38, 213

Senna Hoy, 20, 157

Sensual Ecstasy, 30, 31, 33, 65

Song, A, 49, 211

Song of Love, A, 20, 49, 153
Song of the Playmate Prince, The, 22, 169

Song of Wonder, The, 267

Spring, 33, 49, 57

Spring Sorrow, 45, 103

Styx, 101

Suicide, 30, 81

Then, 49,63

To Apollo, 301

To Daniel Jesus Paul, 191

To Giselheer the Heathen, 22, 39, 165

To Giselheer the Tiger, 22, 173

To Me, 303

To My Child, 19, 43, 49, 227

To My Transfigured Friend, 291

To the Barbarian, 22, 181

To the Barbarian, 22, 49, 183

To the Dear One, 297

To the Duke of Leipzig, 185

To the King of Bohemia, 189

To the Knight of Gold, 24, 161

To the Monk, 207

To the Monk, 209

To You, 89

Turned Inward, 22, 177

Two of Them, The, 97

Unhappy Hate, 30, 91

Unperfected Woman, The, 299

Vagabonds, 30, 33, 95

Viva!, 33, 49, 64

Weltschmerz, 30, 34, 49, 73

Where Might Death Leave My Heart?, 133

Wilhelm Schmidtbonn, 233

You Make Me Sad-Listen, 187

Youth, 45, 49, 83 


\section{Subject Index}

Arthur Aronymus and His Fathers, 25

"Arthur Aronymus: The Story of My

Father," 12

"Astrology," 38

Bänsch, Dieter, 14-15, 28, 37, 40-41, $43,46,48$

Ball, Hugo, 9

Baum, Peter, 24, 217, 305

Bauschinger, Sigrid, 14, 20, 26

Beardsley, Aubrey, 9

Becher, Johannes, 17

Ben-Chorin, Schalom, 47

Benn, Gottfried, 5, 8, 10, 21-22, 31-32, 41-42

"Blue" image, 39

"Child among the Months, The," 15

Cirlot, J. E., 38-40

Cleaning Out!, 19

Cohn, Hans, 20, 23, 29, 32, 38-39, 41-42

Collected Poems, 18, 24, 42

Concert, 15, 25, 27, 40, 43-44, 46

Däubler, Theodor, 3, 13, 24

Dehmel, Richard, 13, 24

Ehrenbaum-Degele, Hans, 19, 24, 42, 159, 305

Ehrenstein, Albert, 24

Fischer, Grete, 31

Gehlhoff-Claes, Astrid, 18-19

George, Stefan, 13, 34, 46-47

Ginsberg, Ernst, 42

Giselheer the Barbarian, 22

Goethe, J. W., 9, 21, 31

"Gold" image, 39-40

Grosz, Georg, 24, 305

Guder, Gotthart, 39

Hart, Julius, 15

Hauptmann, Gerhart, 9

Hebrew Ballads, 24, 40-42
Heine, Heinrich, 48

Hennings, Emmy, 9

Heselhaus, Clemens, 22, 49

Hesse, Hermann, 16

Heym, Georg, 7, 17

Hille, Peter, 3, 10, 15-16, 20, 31, 38, 41

Hiller, Kurt, 19, 32

Hoddis, Jakob van, 7

Hofmannsthal, Hugo von, 13, 20, 23, 47

Holzmann, Johannes, 6, 31-32

$I$ and $I, 26$

Ibsen, Henrik, 12

Jacometti, Bettina, 9

Jesus, 38, 41-42

Joseph, 13, 24, 44

Jussuf of Egypt, 8, 24, 33

Kissing, Jeanette. See Schüler, Jeanette Kissing

Knight of Gold, To the, 24

Kokoschka, Oskar, 19, 24

Kraft, Werner, 23

Kraus, Karl, 3, 14, 18-21, 24, 31, 43

Kupper, Margarete, 24, 27

Land of the Hebrews, 26

Lasker, Berthold, 14

Lasker, Emanuel, 3, 21

Lasker, Paul, 14, 19, 21, 24-25

Laube, Horst, 28

Leppin, Paul, 24, 305

Levin, Georg (see Herwarth Walden)

Lienau, Marianne, 28, 47-48

Loos, Alfred, 24

Malik: An Imperial Story, The, 5, 22-24 passim

Maltzahn, Hans Adalbert von, 24, 42

Mann, Thomas, 8, 35

Marc, Franz, 3, 5, 19, 22-23, 235, 305

Martini, Fritz, 27, 35, 41

Muschg, Walter, 38-39

My Blue Piano, 26, 27, 43

"My Devotion," 44 
My Heart: A Love Novel with Pictures and Really Living People, 18, 23

My Miracles: Poems, 18, 35, 37

New Community, 15

Nietzsche, Friedrich, 13, 23

Nights of Tino of Baghdad, The, 14, 17-18, 26

Otto, Katharina, 19

Parallelismus membrorum, 35

Perotti, Berto, 25

Peter Hille Book, The, 16, 18

Pörtner, Paul, 48-49

"Poor Children of Rich People," 28

Prince of Thebes, 7-8, 18

Prince of Thebes, The, 23, 26, 33

Radecki, Sigismund von, 32, 41

Reeck, Emerich, 11-12

Rilke, R. M., 23, 41

Rouan, Alcibiades de, 14, 32

Sascha, 6

Schlocker, Georges, 38-39, 48-49

Schüler, Aaron, 12
Schüler, Anna, 13

Schüler, Jeanette Kissing, 12-13

Schüler, Paul, 13

Senna Hoy, 6, 32, 42

Seventh Day, The, 17-18, 33-34

Sonnemann, Leopold, 12

Stadler, Ernst, 17

"Star" image, 37-38

Sturm, Der, 17-18

Styx, 14, 17-18, 23, 31-32, 34, 49

Tino of Baghdad, 7-8, 16

Toller, Ernst, 24

Trakl, Georg, 3, 7, 17, 23-24, 48, 219, 305

Visions: Essays and Other Stories, 18, 38

Walden, Herwarth, 11, 17-18, 31, 44

Wallmann, Jürgen, 12

Wegner, Armin T., 8

Werfel, Franz, 17, 24, 215, 306

Werner, Gerhart, 16

Wilhelm, Kurt, 26

Wodtke, F. W., 22

Wupper, The, 18, 24

Zech, Paul, 19, 24 



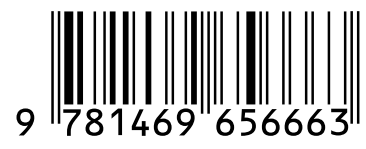

